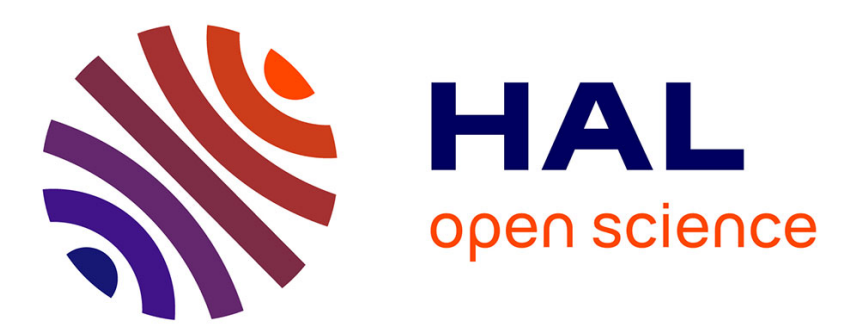

\title{
An intracontinental orogen exhumed by basement-slice imbrication in the Longmenshan Thrust Belt of the Eastern Tibetan Plateau
}

Zhenhua Xue, Wei Lin, Yang Chu, Michel Faure, Yan Chen, Wenbin Ji, Huaning Qiu

\section{To cite this version:}

Zhenhua Xue, Wei Lin, Yang Chu, Michel Faure, Yan Chen, et al.. An intracontinental orogen exhumed by basement-slice imbrication in the Longmenshan Thrust Belt of the Eastern Tibetan Plateau. Geological Society of America Bulletin, 2021, 10.1130/B35826.1 . insu-03186417

\section{HAL Id: insu-03186417 https://hal-insu.archives-ouvertes.fr/insu-03186417}

Submitted on 1 Apr 2021

HAL is a multi-disciplinary open access archive for the deposit and dissemination of scientific research documents, whether they are published or not. The documents may come from teaching and research institutions in France or abroad, or from public or private research centers.
L'archive ouverte pluridisciplinaire HAL, est destinée au dépôt et à la diffusion de documents scientifiques de niveau recherche, publiés ou non, émanant des établissements d'enseignement et de recherche français ou étrangers, des laboratoires publics ou privés. 
1 An intracontinental orogen exhumed by basement-slice-imbrication in the 2 Longmenshan Thrust Belt of the Eastern Tibetan Plateau

3

4 Zhenhua Xue ${ }^{1,2,3}$, Wei Lin ${ }^{2,4}$, Yang $\mathrm{Chu}^{2,4}$, Michel Faure ${ }^{3}$, Yan Chen ${ }^{3}$, Wenbin $\mathrm{Ji}^{5}$, 5 Huaning Qiu ${ }^{6}$

$6{ }^{1}$ School of Earth Sciences, China University of Geosciences, Wuhan 430074, China

$7 \quad{ }^{2}$ State Key Laboratory of Lithospheric Evolution, Institute of Geology and Geophysics,

8 Chinese Academy of Sciences, Beijing 100029, China

$9 \quad{ }^{3}$ Univ. Orléans, CNRS, BRGM, ISTO, UMR 7327, F-45071, Orléans, France

${ }^{4}$ University of Chinese Academy of Sciences, Beijing 100049, China

${ }^{5}$ Department of Geology, Northwest University, Xi'an 710069, China

${ }^{6}$ Key Laboratory of Tectonics and Petroleum Resources (China University of Geosciences), Ministry of Education, Wuhan 430074, China

Corresponding author: Wei Lin (linwei@mail.iggcas.ac.cn)

\section{Key Points}

1. The double-vergent structure of the Longmenshan belt was established during the late Triassic intracontinental underthrusting

2. Boundary faults of the NW-normal faulting and SE-thrusting facilitated the SE-ward basement-slice imbrication

3. The episodic basement-slice imbrication exhumed the early Mesozoic metamorphic rocks

Abstract The Longmenshan Thrust Belt (LMTB) in the Eastern Tibet resulted from a Mesozoic orogeny and Cenozoic reworking. It is generally believed that the Cenozoic tectonics along the LMTB are mostly inherited from the Mesozoic one. Reconstruct the Mesozoic tectonics of the LMTB is therefore important for understanding its evolutionary history. On the basis of detailed structural analysis, we recognized a Main Central Boundary that divides the LMTB into a Southeastern Zone and a Northwestern Zone. Both zones underwent a main $\mathrm{D}_{1}$ event characterized by the $\mathrm{D}_{1 \mathrm{E}}$ top-to-the-SE thrusting in the Southeastern Zone and the $\mathrm{D}_{1 \mathrm{w}}$ top-to-the-NW/N thrusting in the Northwestern Zone. In the Southeastern Zone, a $\mathrm{D}_{2}$ top-to-the-NW/N normal faulting 
that cuts the $\mathrm{D}_{1 \mathrm{E}}$ structures is developed along the NW boundary of the basement complexes. Newly obtained and previous geochronological data indicate that the $\mathrm{D}_{1 \mathrm{E}}$ and $\mathrm{D}_{1 \mathrm{w}}$ event occurred synchronously at $c a .224-219 \mathrm{Ma}$, and the $\mathrm{D}_{2}$ top-to-the-NW/N normal faulting was episodically activated at ca. 166-160 Ma, 141-120 Ma, 81-47 Ma and 27-25 Ma. Episodically and synchronously activated top-to-the-NW normal faulting and top-to-the-SE thrusting along the northwest and southeast boundary of the basement complexes, respectively, let us propose that the basement-slices were episodically imbricated to the SE during the late Jurassic-early Cretaceous and late Cretaceous-earliest Paleocene. The $\mathrm{D}_{1}$ amphibolite-facies metamorphic rocks above the basement complexes recorded fast exhumation during the late Jurassic-early Cretaceous. We propose that the early Mesozoic northwestward basement underthrusting along a crustal "weak zone" was responsible for the $\mathrm{D}_{1}$ double-vergent thrusting and amphibolite-facies metamorphism. Subsequent basement-slice imbrications reworked the LMTB and exhumed the amphibolite-facies rocks. Our results highlight the importance of basement underthrusting and imbrication in the formation and reworking of the intracontinental Longmenshan Thrust Belt in the Eastern Tibet.

\section{Introduction}

The Longmenshan Thrust Belt (LMTB; Figure 1a), at the eastern margin of the Tibetan Plateau, has attracted attentions of geologists due to the paradox between low convergence rate (Zhang et al., 2004; Shen et al., 2009) and extremely high topographic gradient (Clark and Royden, 2000; Royden et al., 2008) as well as intense seismic activities (e.g., 2008 Wenchuan Mw 7.9 earthquake, 2013 Lushan Mw 7.0 earthquake, and 2017 Jiuzhaigou Mw 7.0 earthquake). This paradox has spawned a vigorous debate regarding the roles of upper crustal faulting (Hubbard and Shaw, 2009) and lower crust channel flow (Royden et al., 2008) in building and maintaining such a high Tibetan Plateau margin. However, both models attribute shortening and crustal thickening of the LMTB to the late Cenozoic evolution, and underestimate the importance of widely recognized Mesozoic tectonics along the LMTB (Xu et al., 1992; Burchfiel et al., 1995;

Worley and Wilson, 1996). Furthermore, it has been reached a consensus that the 4 LMTB is mainly inherited from the Mesozoic tectonic framework (Burchfiel et al., 
1995; Meng et al., 2005). Elucidating the Mesozoic tectonics of the LMTB and its adjacent areas is therefore crucial to understand the tectonic evolution of the LMTB.

The prominent deformation recorded in the LMTB and adjacent areas is indicated by observations including: 1) the peripheral foreland basin formed due to the southeastward thrusting and loading of the LMTB (Chen et al., 1994; Li et al., 2003); 2) the early Jurassic rocks unconformable overly extensively folded late Triassic rocks (BGMRSP, 1991; Xu et al., 1992; Burchfiel et al., 1995); 3) the pervasive orogenparallel klippen and nappe belt sitting on the foot hills of the Longmen Mountains are believed related to the regional top-to-the-SE thrusting (Figure 2); 4) the consistent topto-the-SE thrusting indicated by different indicators at various scales (Xu et al., 1992; Burchfiel et al., 1995; Chen et al., 1995; Chen and Wilson, 1996; Jia et al., 2006; Yan et al., 2011; Yan et al., 2018); 5) the pervasive upright folding in the adjacent SongpanGanzi Terrane was thought synchronous to the early Mesozoic deformation of the LMTB (Burchfiel et al., 1995; Chen et al., 1995; Harrowfield and Wilson, 2005). This prominent deformation event was constrained to $c a$. 234-200 Ma by basin tectonics, timing of the top-to-the-SE/SSE shearing and syntectonic metamorphism, which indicated an early Mesozoic orogeny of the LMTB (Chen et al., 1994; Li et al., 2003; Yan et al., 2011; Zheng et al., 2014; Xue et al., 2016; Zheng et al., 2016; Airaghi et al., 2018a; Airaghi et al., 2018b; Yan et al., 2018).

The early Mesozoic tectonic evolutionary mechanism accounting for the above observations, however, is still in dispute. Sengör (1984) and Luo (1991) suggested that the LMTB is an early Mesozoic intracontinental subduction zone accommodating multi-stage crustal shortening. Then, Xu et al. (1992) proposed a bivergent subduction model in which the Songpan-Ganzi Terrane sedimentary cover has been "pushed" to the southeast on top of the Yangtze Block due to the bivergent subduction along the Anymaqen and Jinshajiang Suture Zones. The current models suggested that the Songpan-Ganzi sedimentary cover were overthrust southwards on the Yangtze Block along a decollement in response to the closure of the Paleotethys (Mattauer et al., 1992; Calassou, 1994; Dirks et al., 1994; Chen and Wilson, 1996; Worley and Wilson, 1996; Roger et al., 2004; Harrowfield and Wilson, 2005; de Sigoyer et al., 2014; Yan et al., 2018).

Apart from the early Mesozoic top-to-the-SE/SSE thrusting along the LMTB, an increasing number of studies proposed a top-to-the-NW normal faulting that developed 
along the NW boundary of the orogen-parallel and stripped Neoproterozoic complexes (Figure 1b)(Xu et al., 2008; Zhou et al., 2008; Tian et al., 2016; Billerot et al., 2017; Xue et al., 2017; Airaghi et al., 2018b). However, timing and significance of the topto-the-NW normal faulting are in dispute that have resulted in several different models, such as: 1) mid-Jurassic to early Paleogene (173-160 Ma and 81-47 Ma) post orogenic extension (comparing to the early Mesozoic orogeny)(Zhou et al., 2008), 2) early Cretaceous ( 120 Ma) crustal-scale wedge extrusion (Xu et al., 2008), 3) episodic eastward basement-slice-imbrication during the late Jurassic-early Cretaceous and late Cretaceous-Earliest Paleogene (Billerot et al., 2017; Xue et al., 2017), and, 4) formation of a late Cretaceous-earliest Paleogene crustal scale duplex (Tian et al., 2016). Based on the above compilation, most previous works have proposed that the top-to-the-NW normal faulting occurred in the late Mesozoic.

Major questions therefore remain unsolved: 1) Considering previous early Mesozoic tectonic models of the LMTB, whether did the significant shortening recorded in the LMTB correspond to the imbricated thrust system during the Paleotethys' closure, or to the intracontinental underthrusting along the Longmenshan belt? 2) What is the tectonic significance of the top-to-the-NW normal faulting (mostly late Mesozoic) and emplacement of the Neoproterozoic complexes? Therefore, an overall accurate reconstruction of the Mesozoic tectonics of the LMTB and its adjacent areas, especially its detailed structural analysis and timing, are of great importance.

This study presents detailed field investigations focusing on structural geometry and kinematic reconstruction, and geochronological constraints including zircon $\mathrm{U}-\mathrm{Pb}$ dating of synkinematic plutonic rocks and ${ }^{40} \mathrm{Ar} /{ }^{39} \mathrm{Ar}$ dating on the synmetamorphic micas of the LMTB. In conjunction with previous published geochronological and metamorphic data, a new geodynamic model was proposed to interpret the Mesozoic tectonic evolutionary history of the LMTB.

\section{Geological Setting}

At the eastern margin of the Tibetan Plateau, the LMTB separates the intensely folded and metamorphosed (Greenschist facies grade) Songpan-Ganzi Terrane to the NW, and the weakly/undeformed Sichuan Basin to the SE (Figure 1a). The triangleshaped Songpan-Ganzi Terrane is separated from the western Qinling-Dabie Orogenic 
Belt to the north by the East Kunlun-Anymaqen Suture Zone, from the Qiangtang Block to the southwest by the Jinshajiang Suture Zone (Figure 1a).

\subsection{Songpan-Ganzi Terrane}

The Songpan-Ganzi Terrane mainly comprises $\sim 5-15 \mathrm{~km}$-thick intensely folded late Triassic turbidites (Calassou, 1994; Harrowfield and Wilson, 2005; Zhang et al., 2006c; Zhang et al., 2008; Yin, 2015). The provenance of the turbidites includes the Kunlun Mountains, North China Block, South China Block and southwest Qinling Orogenic Belt (Yin and Nie, 1993; Enkelmann et al., 2007; Weislogel et al., 2010). Voluminous felsic plutons intruded the Songpan-Ganzi Terrane at ca. 226-205 Ma, dominantly derived from partial melting of the Neoproterozoic basement and sedimentary cover of the Songpan-Ganzi Terrane, with negligible amounts of mantle material (Figure 1b)(Roger et al., 2004; Hu et al., 2005; Zhang et al., 2006b; Zhang et al., 2007; de Sigoyer et al., 2014). Both geophysical and geological data indicate a continental crust of Yangtze Block affinity underlying the eastern Songpan-Ganzi Terrane (Roger et al., 2004; Hu et al., 2005; Zhang et al., 2009; Weislogel et al., 2010; Zhang et al., 2010; Guo et al., 2013).

\subsection{Sichuan Basin of the Yangtze Block}

The Sichuan Basin, located in the Yangtze Block of northwest South China Block (Figure 1a), preserves a Paleoproterozoic to Neoproterozoic basement overlain by Neoproterozoic to Cenozoic sedimentary sequences. Silurian-Devonian abyssal deposits and radiolarian chert suggested a long period of rifting during the Silurian to Devonian ages along the western part of the Yangtze Block (Long, 1991; Luo, 1991; Chang, 2000; Li, 2009). This rift was revealed by high-resolution seismic reflection profile as well (Jia et al., 2006). During middle-late Triassic ages, coeval with the southeastward thrusting and loading of the LMTB, the western Sichuan Basin began subsiding flexurally and evolved into an epicontinental foreland basin (Figure 2). Thrust sheets were transported to the southeast synchronously and intensely folded at the end of the late Triassic (Chen et al., 1994; Chen and Wilson, 1996; Li et al., 2013c). The continuous sedimentation of the middle Jurassic-upper Cretaceous deposits implies a pronounced subsidence at the western Sichuan foreland basin during this period (Burchfiel et al., 1995; Chen et al., 1995). Episodic SE-ward thrusting and loading of the LMTB were indicated by the wedge-shaped megasequences of the western Sichuan foreland basin, namely, in late Triassic-early Jurassic, late Jurassic- 
163

164

165

166

167

168

169

170

171

172

173

174

175

176

177

178

179

180

181

182

183

184

185

186

187

188

189

190

191

192

193

194

early Cretaceous and late Cretaceous-earliest Paleocene (Xu et al., 2008; Li et al., 2013c; Tian et al., 2016).

\subsection{The LMTB}

The NE-striking LMTB merges into the western Qinling Orogenic Belt to the northeast and is truncated by the Xianshuihe Fault to the southwest (Figure 1a).

\subsubsection{Major faults of the LMTB}

The regional tectonic architecture of the LMTB is defined by four major NE-SW striking faults, namely from the southeast to the northwest, the Anxian-Guanxian Fault ( $\mathrm{T}_{1}$ in Figure $\left.1 \mathrm{~b}\right)$, the Yingxiu-Beichuan Fault $\left(\mathrm{T}_{2}\right.$ in Figure $\left.1 \mathrm{~b}\right)$, the WenchuanMaoxian Fault ( $\mathrm{T}_{3}$ in Figure 1b), and the Qingchuan-Pingwu Fault ( $\mathrm{T}_{4}$ in Figure $\left.1 \mathrm{~b}\right)$. The Anxian-Guanxian Fault dips to the northwest by $30-50^{\circ}$ and crosscuts the late Triassic-early Jurassic rocks. Approaching northwestwards, the Yingxiu-Beichuan Fault dipping $40-60^{\circ}$ to the NW separates the Sichuan foreland basin to the southeast from the LMTB hinterland (BGMRSP, 1991; Xu et al., 1992; Burchfiel et al., 1995). The Wenchuan-Maoxian Fault dipping $30-50^{\circ}$ to the NW was episodically activated since ca. 220 Ma (Burchfiel et al., 1995; Yan et al., 2008; Zheng et al., 2016). Seismic reflection profile showed that the ENE-striking Qingchuan-Pingwu Fault dips to the NNW or SSE at variable angles (Wang et al., 2000; Jia et al., 2006; Lin et al., 2014). The northern LMTB was dissected by the Qingchuan-Pingwu Fault and incorporated to northwestward- and southeastward-thrusting that resemble a positive flower structure (Jia et al., 2006). The Wenchuan-Maoxian Fault and Qingchuan-Pingwu Fault are characterized by mylonite overprinted by breccia and gouge (Chen and Wilson, 1996; Li et al., 2013a; Li et al., 2015).

\subsubsection{Basement complexes in the LMTB}

The basement complexes that distributes from the NE to the SW in the LMTB are composed of Neoproterozoic meta-granites overlain by a Neoproterozoic metasedimentary cover, such as the Danba (DB), Kanding (KD), Wulong (WL), Baoxing (BX), Pengguan (PG), Moutuo (MT), Xuelongbao (XLB) and Jiaoziding (JZD) complexes (Figure 1b). These basement complexes share similar lithology with the Yangtze Block basement (BGMRSP, 1991). Field observations, Anisotropy of Magnetic Susceptibility (AMS) and gravity modeling have suggested that these basement complexes were strongly deformed and imbricated southeastwards as 
basement-slices (Ma et al., 1996; Xu et al., 2008; Tian et al., 2016; Airaghi et al., 2017b; Billerot et al., 2017; Xue et al., 2017).

\subsubsection{Metamorphism in the LMTB}

Two amphibolite facies metamorphic zones have been recognized in the metasedimentary cover in the Wenchuan-Xuelongbao area and the Danba area (Dirks et al., 1994; Huang et al., 2003a; Zhou et al., 2008; Airaghi et al., 2018a; Airaghi et al., 2018b).

Petrological studies (garnet-amphibolite-biotite thermometer, pseudosection using Perplex modeling and chlorite-white mica-quartz thermal dynamic equilibrium) constrain the peak metamorphic conditions at $\sim 11 \pm 2 \mathrm{kbar}, \sim 620^{\circ} \mathrm{C}$ in the WenchuanXuelongbao area (Dirks et al., 1994; Airaghi et al., 2018a) and 5.3-8 kbar, 570-680 ${ }^{\circ} \mathrm{C}$ in the Danba area (Huang et al., 2003a; Weller et al., 2013). The WenchuanXuelongbao metamorphic belt reached amphibolite facies conditions at ca. 210-180 Ma (Airaghi et al., 2018a; Airaghi et al., 2018c) and recorded fast exhumation at ca. 140-120 Ma (Arne et al., 1997; Airaghi et al., 2018c). The Danba amphibolite-facies metamorphic belt reached peak conditions at ca. 205-180 Ma (Huang et al., 2003a; Weller et al., 2013) and initiated enhanced rapid cooling at ca. 168-158 Ma (Huang et al., 2003a; Zhou et al., 2008).

Apart from these two amphibolite facies metamorphic zones, late Triassic blueschists occur as lenses along the Qingchuan-Pingwu Fault, with peak metamorphic pressure attained to 5.2-6.5 kbar (Wei, 1994; Xu et al., 2020). The blueschist then have been retrograded to greenschist in a nearly isothermal decompression way (Wei, 1994).

\subsubsection{Tectonic events of the LMTB}

The LMTB recorded at least three phases of deformation, including (1) $\mathrm{D}_{1}$, the late Triassic to early Jurassic regional top-to-the-SE thrusting, (2) $\mathrm{D}_{2}$, the top-to-the-NW/N normal faulting of poorly constrained timing and tectonic significance, and (3) $\mathrm{D}_{3}$, the Cenozoic shortening reactivation (Xu et al., 1992; Burchfiel et al., 2008; Richardson et al., 2008; Xu et al., 2008; Li et al., 2013a; Li et al., 2015; Tian et al., 2016; Xue et al., 2017). The $D_{1}$ deformation is well identified by penetrative cleavages $\left(S_{1}\right)$, mineral and stretching lineation $\left(\mathrm{L}_{1}\right)$ in the Wenchuan area, and the top-to-the-SE thrust sheets and nappes over the intensely folded late Triassic sequences in the western Sichuan foreland basin (Xu et al., 1992; Burchfiel et al., 1995; Worley and Wilson, 1996; Li et al., 2003). Most parts of the Songpan-Ganzi Terrane show slow cooling rate at $c a .1{ }^{\circ} \mathrm{C} / \mathrm{Ma}$ since the early Mesozoic (Huang et al., 2003a; Huang et al., 2003b; Roger et al., 2011). 
However, an enhanced cooling event $\left(\mathrm{ca} .8^{\circ} \mathrm{C} / \mathrm{Ma}\right)$ during the late Jurassic to Eocene was reported at the peripheries of the Songpan-Ganzi Terrane, especially in the

230 Wenchuan and Danba areas (Yuan et al., 1991; Arne et al., 1997; Huang et al., 2003a).

231 This rapid cooling event probably responded to the $\mathrm{D}_{2}$ top-to-the-NW/N normal 232 faulting. The belt characterized by the top-to-the-NW normal faulting developed along 233 the northwest/north boundary of the basement complexes was entitled as the East Tibet 234 Detachment (Wang et al., 2012b). The $\mathrm{D}_{3}$ deformation was thought to have initiated since $c a$. 30-25 Ma that builds the present Longmen mountains of the eastern Tibetan Plateau (Clark and Royden, 2000; Kirby et al., 2002; Wang et al., 2012a).

\section{Structural analysis of the LMTB}

\subsection{Structural subdivisions of the LMTB}

The LMTB was interpreted as an allochthonous sheet thrusting southeastward upon the autochthonous western Sichuan Foreland Basin (Xu et al., 1992; Burchfiel et al., 1995; Worley and Wilson, 1996; Robert et al., 2010a). Based on structural investigations, we present revised structural subdivisions of the LMTB. Firstly, the LMTB is divided into a Southeastern Zone and a Northwestern Zone by a Main Central Boundary (see Section 3.2; Figure 3a). According to the lithology, deformation intensity, and metamorphic grade, the Southeastern Zone can be further subdivided into four subdivisions (Figure 3). They are, from the southeast to the northwest: i) the undeformed Autochthon that comprises the western part of the Sichuan Foreland Basin, ii) the Para-autochthon, transported southeastwards along the Anxian-Guanxian Fault and rests over the Autochthon, iii) the Allochthon that traveled southeastwards much further on top of the Para-autochthon, and iv) the Inner Metamorphic Core that recorded the highest metamorphic conditions (i.e., amphibolite facies) among the Southeastern Zone. The four subdivisions in the Southeastern Zone are separated by the three major listric faults of the LMTB (Figure 3; see in Section 2.3.1).

i) The Autochthon, located to the southeast of the Anxian-Guanxian Fault, is mainly composed of Jurassic-Cretaceous strata and overlying Cenozoic sediments (Figures 3 and 4). The Jurassic-Cretaceous strata were deposited in circumstances of alluvial, fluvio-deltaic, and lacustrine fills, characterized by medium and coarse-grained sandstone with some conglomeratic layers at the base. Total thickness of the JurassicCretaceous sequences is more than $5 \mathrm{~km}$ (BGMRSP, 1991). In the northern part of the 
LMTB, close to Anxian and Jiangyou county, the early Jurassic and overlying Cretaceous to Cenozoic sequences are dipping to the southeast that unconformably rest on the intensively folded late Triassic rocks (Figures 2 and 4c-d)(BGMRSP, 1991).

ii) The Para-autochthon is sandwiched by the Anxian-Guanxian Fault and the Yingxiu-Beichuan Fault, with its half area covered by klippen and nappes from the Allochthon (Figure 3). The Late Triassic Xujiahe Formation dominated in this subdivision either passes up from the earliest late Triassic marine sandstone or unconformably overlies the middle Triassic limestone (Li et al., 2003; Meng et al., 2005). The Xujiahe Formation shows markable lateral variation in both thickness and sedimentary facies. Coarse-grained sediments, such as alluvial conglomerate bodies occur close to the Yingxiu-Beichuan Fault, but change into fine-grained lacustrine sediments toward to the basin interior.

iii) The Allochthon is mainly exposed between the Wenchuan-Maoxian Fault and the Yingxiu-Beichuan Fault, and also includes the klippen and nappes resting on top of the Para-autochthon (Figures 2 and 3a). Northwest to the Yingxiu-Beichuan Fault, this subdivision mainly consists of Silurian shale and greywacke with the bedding completely transposed into foliation. Greenschist-facies metamorphism is indicated by mineral assemblages of fine-grained muscovite + chlorite + quartz (Airaghi et al., 2017b; Xue et al., 2017). Metamorphic condition jumps of $\sim 50{ }^{\circ} \mathrm{C}, 3-5 \mathrm{kbar}$ southeastwards across the Yingxiu-Beichuan Fault suggest that the Allochthon are more deformed and metamorphosed in a deeper structural level than the Paraautochthon (Robert et al., 2010a; Airaghi et al., 2018b). Neoproterozoic complexes including the Pengguan and Jiaoziding complexes are distributed in this subdivision.

284 Southeast to the Yingxiu-Beichuan Fault, klippen and nappes are mainly composed of 285 Devonian to early Triassic thick-bedded limestone and marine sandstone (Figures 2, 3 286 and $4 a-d)$.

iv) The Inner Metamorphic Core comprises phyllite and micaschist that are mostly metamorphosed Silurian sediments (Figures 2 and 3). Amphibolite-facies metamorphic zone that wraps the oval-shaped Xuelongbao (XLB in Figure 2) and stripped Moutuo

290 (MT in Figure 2) complexes records the highest-grade metamorphism within the 291 Southeastern Zone (Dirks et al., 1994; Airaghi et al., 2017a; Airaghi et al., 2018a). Peak $292 \mathrm{P}-\mathrm{T}$ condition attained to $\sim 11 \pm 2 \mathrm{kbar}$ and $\sim 620^{\circ} \mathrm{C}$ at the southernmost margin of the 293 Xuelongbao complex calculated from metamorphic assemblages of biotite + garnet + 
staurolite + muscovite + kyanite (Dirks et al., 1994; Airaghi et al., 2018a). Based on the enhanced metamorphic grade and deformation intensity, the Inner Metamorphic

296 Core are therefore more deformed and metamorphosed in a deeper structural level than 297 the Allochthon.

298 The Northwestern Zone includes eastern Songpan-Ganzi Terrane with 299 Neoproterozoic sequences outcropped in the north and Paleozoic sequences outcropped 300 in the south (Figures 2 and 3). The northern Northwestern Zone mainly consists of two 301 Neoproterozoic Groups, namely, 1) the volcanic Bikou Group defined by mafic lavas 302 within its lower part and ranges from mafic to intermediate-felsic within its upper 303 portion, and 2) the Hengdan Group tectonically resting on the Bikou Group is composed 304 of black, thin-bedded pyrite-bearing shales and interbedded thinly volcaniclastic 305 sandstone and siltstone (Yan et al., 2003; Druschke and Wang, 2006). The southern 306 Northwestern Zone includes Devonian Weixian Formation and the Triassic sequences. 307 The Devonian sequences consist mainly of quartziferous phyllite to schist and 308 interbeded quartzite. The overlying Triassic Xikang Group is dominated by thick and 309 highly repetitious flysch sediments. Although different rock units comprising the 310 northern and southern Northwestern Zone, it was metamorphosed under similar 311 greenschist facies conditions (Figures $1 \mathrm{~b}$ and 2)(Xu et al., 1992; Liu et al., 2008) Northwestern Zone and the Southeastern Zone. It corresponds to the southern branch of the Qingchuan Fault ( $\mathrm{T}_{4}$ in figure 2) in the north (BGMRSP, 1991), and to a vertical

\subsection{The Main Central Boundary}

The Main Central Boundary serves as a major tectonic boundary separating the cleavage zone within the Paleozoic rocks in the south (Figure 2). To the SE of the Main Central Boundary, all structural planes in the Southeastern Zone, including foliations, cleavages, and fold axial planes, are exclusively dipping to the NW. Various kinematic indicators in the Southeastern Zone suggest a consistent top-to-the-SE/S thrusting. To the NW of the Main Central Boundary, the Northwestern Zone is characterized by the SSE-dipping planar structures and associated top-to-the-NW thrusting (Figure 3).

The Qingchuan-Pingwu Fault, as the northern segment of the Main Central Boundary, is a major tectonic boundary. Seismic profiles, drill data (Jia et al., 2006) and field observations indicate that the Qingchuan-Pingwu Fault is a positive flower structure developed in a transpressional system. Microfabric study (Wang et al., 2000) 
indicated that the Qingchuan-Pingwu Fault was originated from a deep-seated ductile shear zone during late Triassic and overprinted by Cenozoic brittle deformation at very least. It is the late Triassic deep-seated ductilely sheared Qingchuan-Pingwu Fault rather than the Cenozoic brittle one that separates the LMTB into the Southeastern Zone and Northwestern Zone.

The southern segment of the Main Central Boundary roughly distributes along the geological boundary between the Silurian and Devonian-Permian sequences (Figure 2). Macroscopically, this segment of Main Central Boundary shows predominant vertical cleavage and foliation within intensely deformed argillaceous limestone, graphitic pelite and thin-bedded limestone-quartz ribbon interlayers (Figures 3a and 5). Their bedding $\left(\mathrm{S}_{0}\right)$ can be distinguished by the compositional variations that is parallel to the cleavages (Figure $3 \mathrm{a}$ and $5 \mathrm{~b}$ ). Associated rootless folds imply significant shortening during the formation of the Main Central Boundary (Figures 3a and 5b-c). P-wave receive function and seismic reflection profiles revealed a Moho at $\sim 36-40 \mathrm{~km}$ depth beneath the Sichuan Basin that gradually deepens northwestwards at $\sim 63 \mathrm{~km}$ depth beneath the eastern Tibet (Guo et al., 2013). This transition occurs beneath the Wenchuan Shear Zone (corresponding to Inner Metamorphic Core) over a horizontal distance of fewer than $30 \mathrm{~km}$ (Robert et al., 2010b; Zhang et al., 2010; Guo et al., 2013). Geophysical profiles, therefore, support the statement that the southern Main Central Boundary, as the northwest boundary of the Inner Metamorphic Core, serves as a major tectonic boundary.

\subsection{The main deformation $\left(\mathrm{D}_{1}\right)$}

The $\mathrm{D}_{1}$ main deformation is defined by a NW-SE striking stretching lineation recognized in both the Southeastern and Northwestern zones which is separated by the Main Central Boundary (Figure 2). Kinematic indicators indicate a top-to-the-SE thrusting and a top-to-the-N/NW thrusting in the Southeastern and the Northwestern zones, respectively. Since there is no evidence of superposition between these two senses of shear, it is difficult to precisely define the relative timing of these opposite shearing events. Nevertheless, to clarify the presentation of the deformation events, in the following, we distinguish $\mathrm{D}_{1 \mathrm{E}}$, the top-to-the-SE thrusting in the Southeastern Zone, and $\mathrm{D}_{1 \mathrm{~W}}$, the top-to-the-NW/N thrusting in the Northwestern Zone, respectively.

$$
\text { 3.3.1 Top-to-the-SE thrusting in the Southeastern Zone }\left(\mathrm{D}_{1 \mathrm{E}}\right)
$$


The top-to-the-SE shearing and thrusting are widespread in the Southeastern Zone at variable scales, except that the Autochthon merely recorded long-wavelength fold and monoclines toward the interior of the Sichuan Basin (Figure 4). The $\mathrm{D}_{1 \mathrm{E}}$ top-tothe-SE thrusting is most developed in the Inner Metamorphic Core and generally attenuated southeastwards.

The Inner Metamorphic Core was ductilely deformed showing predominant NWdipping foliation $\left(\mathrm{S}_{1}\right)$ at varied angles between $60-90^{\circ}$. Specifically, the foliation gradually steepens when approaching the Main Central Boundary, and eventually presents in a vertical attitude (Figures 2-4). This changing trend of foliation implies that the deformation intensified toward the Main Central Boundary. Foliations mostly consist of an alternation of biotite-white mica-rich and light-colored, pelitic interlayers (Figures $3 \mathrm{a}$ and $6 \mathrm{a}-\mathrm{b}$ ). Along the transect from Wenchuan county to Xuecheng town, an NW-plunging mineral and stretching lineation $\left(\mathrm{L}_{1}\right)$ defined by aligned newly formed biotite, white mica, elongated quartz aggregates, or iron-oxide pods are well developed (Figures $3 \mathrm{a}$ and 6a). Kinematic indicators document a consistent top-to-the-SE thrusting in the Inner Metamorphic Core. Such as asymmetric pyrite pressure shadow in mica-schist (Figures $3 \mathrm{a}$ and $6 \mathrm{~b}$ ) and sigma-shaped feldspar porphyroclasts in paragneiss (Figures 3a and 6c) both show top-to-the-SE thrusting. Photomicrographs (perpendicular to the foliation and parallel to the lineation) show that newly formed white mica oriented as compaction plane (S) and shear plane (C), both of which composes an S-C fabric documenting a consistent top-to-the-SE thrusting (Figures 3a and $6 \mathrm{~d})$.

In the Allochthon, the Neoproterozoic complexes such as the Pengguan and Jiaoziding complexes, mostly show brittle deformation characterized by subhorizontal joints. Inside the Pengguan complex, several NE-SW trending ductile shear zones dissected and thrust the granitic rocks to the southeast (Airaghi et al., 2017b; Xue et al., 2017). Upon the granitic rocks, the Neoproterozoic Huangshuihe Group recorded extensive shearing and sigmoid pelitic lens incorporated to the top-to-the-SE thrusting (Figures $3 \mathrm{a}$ and 6e). Structural planes including axial planar cleavages and spaced cleavages dip to the northwest at angles of $30-65^{\circ}$ (Figures 2-4). Fine-grained white mica and chlorite are developed on these structural planes demonstrating a greenschist facies grade of deformation. Sigma-shaped sandy lens in the Silurian pelitic schist indicate a top-to-the-SE thrusting as well (Figures 3a and 6f). 
As part of the Allochthon, most of the klippen are synclines overturned to the SE, with SE-ward reverse fault which dissected the thick Devonian limestone at the rear of the klippe (Figures 2 and 6g), and show a consistent top-to-the-SE thrusting (BGMRSP, 1991).

In the Para-autochthon, the late Triassic Xujiahe sandstone is intensively folded as indicated by the NE-SW trending $\pi$-circle-projected axis of bedding (Figures $3 b-d$ ). In the south part, multi $\pi$ circle-Axis exist roughly trending NE-SW, implying multiphase of shearing and thrusting. Folds are mostly overturned to the SE indicating a top-tothe-SE thrusting (Figure 2). Axial planar cleavages are locally developed that gradually intensified and more penetrative approaching northwestward to the Yingxiu-Beichuan Fault. This cleavage-enhancing trend implies a northwestward increase in deformation intensity. In mudstone-sandstone interlayered rocks, competence contrast facilitates the formation of layer-parallel slip and shearing. Sigmoid lens as well as "cold" shearband fabrics consistently indicate a top-to-the-SE thrusting (Figures 3a and 6h).

In the Autochthon, lower Jurassic strata and overlying continuous CretaceousCenozoic sequences are mostly concordantly folded in a long-wavelength way. The fact that early Jurassic rocks locally overturned to the southeast (North to the Tangbazi town; Figure 2) therefore implies a post-Jurassic reactivation of the SE-directed thrusting (Figures 2 and 4d).

\subsubsection{Top-to-the-NW/N thrusting in the Northwestern Zone $\left(\mathrm{D}_{1 \mathrm{w}}\right)$}

The structures and kinematics within the Northwestern Zone are different from those within the Southeastern Zone. In the northern Northwestern Zone, S-dipping foliation and associated downdip lineation are well developed. Lineations are defined by aligned calcite, fine-grained white mica, and oxide pods (Figures 2, 3a and 7a). Along the lineation, a consistent top-to-the-N/NW shearing and thrusting is determined by various kinematic indicators, such as sigma-shaped pebbles in strongly sheared metaconglomerate (Figures $3 \mathrm{a}$ and $7 \mathrm{~b}$ ) and asymmetric pressure shadow in sandy-pelitic schist. Photomicrographs show that quartz ribbon (Figures $3 \mathrm{a}$ and $7 \mathrm{c}$ ) and sigma-shaped feldspar porphyroclasts (Figures $3 \mathrm{a}$ and $7 \mathrm{~d}$ ) both indicate a top-to-the-N thrusting. In the north of the Pingwu city, greywacke and siltstone were extensively folded verging to the north with associated meter-scale reverse fault cutting fold limbs (Figures $3 \mathrm{a}$ and 7e). West to the Pingwu city, bedding (depicted by compositional banding) completely 
transposed to SE-dipping foliations in response to the northward shearing and thrusting (Figures $3 \mathrm{a}$ and $7 \mathrm{f}$ ).

In the southern Northwestern Zone, axial planar cleavage developed in the thinbedded limestone mostly dips to the SE but strikes roughly along the margin of the Xuelongbao complex (Figure 2). On the foliation, lineation plunges to the SE at $\sim 65-$ $70^{\circ}$ (Figures 2 and $3 \mathrm{a}$ ). Along the lineation, asymmetric pressure shadow of calcite tail around garnet pseudomorph indicates a top-to-the-NW thrusting (Figures 3a and 7g). Asymmetric NW-verging folds are developed at different scales. The late Triassic turbidite was involved in a hundred-meter scale chevron fold verging to the NW that is consistent with the top-to-the-NW thrusting (Figures $3 \mathrm{a}$ and $7 \mathrm{~h}$ ). In the whole Northwestern Zone, the top-to-the-NW/N thrusting is indicated by the pervasive NW/N-overturned bedding as well (Figure 2)(BGMRSP, 1991).

\subsubsection{Syntectonic $\left(D_{1 w}\right)$ Mupi pluton in the Northwestern Zone}

In the Northwestern Zone, north of the Pingwu city, the Mupi pluton is a coarsegrained diorite and granodiorite pluton with prominent syntectonic features (Figure 2). At its southern margin, the contact between the pluton and the country rock is rather ambiguous. Strong mylonitisation with S-dipping foliation deformed both the country rocks and the south margin of the pluton (Figures 3a and 8c). On the S-dipping foliation $\left(\mathrm{S}_{1}\right)$, aligned biotite and sheared feldspar define a mylonitic lineation plunging south at $\sim 45-75^{\circ}$. Kinematic indicators including sigmoidal feldspar porphyroclasts and shearbands both indicate a top-to-the-N shearing related to thrusting (Figures 3a and 8d). About 10-15 meters northwards from the south margin of the pluton, a set of quartz + feldspar veins parallel to the shear foliation (Figures $3 \mathrm{a}$ and $8 \mathrm{~b}$ ), in which the quartz and feldspar did not record ductile deformation. Further north $\sim 30$ meters from the south margin of the pluton, the pluton rocks show magmatic fabric with euhedral feldspar randomly distributed (Figures 3a and 8a). Cracks in feldspar grains are subparallel to the shear planes and infilled with quartz (Figures 8e and S1). These cracks in conjunction with the foliation-parallel quartz + feldspar veins indicate that a brittle deformation of the feldspar occurred in the presence of residual melt. Therefore, based on the textural criteria proposed by Paterson et al. (1989), we prefer to interpret the Mupi pluton as a syntectonic one relating to the $\mathrm{D}_{1 \mathrm{w}}$ deformation. 
3.4 Top-to-the-NW normal faulting along the northwest boundary of the basement complexes $\left(\mathrm{D}_{2}\right)$

Most of the Neoproterozoic basement complexes in the Southeastern Zone are devoid of ductile deformation but characterized by widespread subhorizontal joints (Xue et al., 2017). Mylonite is localized along the northwest boundary of the Xuelongbao and Pengguan complexes. Along the western boundary of the Xuelongbao complex, foliation dips to the NW at $45-80^{\circ}$ with lineation plunging to the west (Figure 2). These structural foliations and lineations are difficult to distinguish from those of the $\mathrm{D}_{1 \mathrm{E}}$ deformation structures. However, sigmoidal feldspar clasts and $\mathrm{S} / \mathrm{C}$ fabric indicate different kinematics of top-to-the-NW normal faulting (Figures $3 \mathrm{a}$ and $9 \mathrm{a}$ ). The Silurian rock directly overlies the Neoproterozoic Pengguan complex also supports NW-ward normal faulting (Figure 2).

Along the northwest boundary of the Pengguan complex, mylonitic foliation dips to the NW at high angles of $\sim 80^{\circ}$ (Figures $3 \mathrm{a}$ and $9 \mathrm{~b}$ ) with lineation steeply plunging to the NW, except for a few SE- or N-dipping foliations that probably resulted from tilting of the original foliations by the Cenozoic deformation (Figure 2). Photomicrographs including asymmetric mica fishes (Figures $3 \mathrm{a}$ and 9c), sigmoidal feldspar porphyroclasts (Figures 3a and 9d), and S/C fabric of white mica (Figures S2c and e) indicate a top-to-the-NW normal faulting. The deformed rocks experienced syntectonic greenschist-facies metamorphism with a mineral assemblage of quartz + feldspar + biotite + white mica + chlorite (Figures S2e-f).

Microscopic structures from the northwest Pengguan complex show sigma-shaped porphyroclast, quartz ribbon (Figures $3 \mathrm{a}$ and 9f), and white mica shear-band fabric (Figures $3 \mathrm{a}$ and $9 \mathrm{~g}$ ), indicating a top-to-the-SE shearing related to the $\mathrm{D}_{1 \mathrm{E}}$ deformation. However, all these structures are cut by NW-dipping shear-bands (Figures 3a and 9e). In the western flank of the Wulong complex, about $60 \mathrm{~km}$ southwest to the Pengguan complex, a similar top-to-the-NW normal fault with greenschist-facies metamorphism

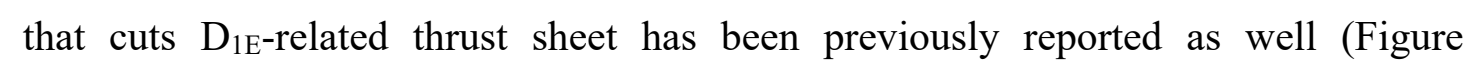
1b)(Burchfiel et al., 1995; Tian et al., 2016; Airaghi et al., 2018b). Thus, we interpret the top-to-the-NW normal faulting in the northwest Pengguan complex and the Xuelongbao complex as the $\mathrm{D}_{2}$ event after the $\mathrm{D}_{1 \mathrm{E}}$ top-to-the-SE thrusting in the Southeastern Zone. 


\section{Geochronological constraints}

In order to constrain the timing of the $\mathrm{D}_{1}$ double-vergent thrusting and the $\mathrm{D}_{2}$ topto-the-NW normal faulting, SIMS U-Pb dating on zircons from the synkinematic Mupi pluton and ${ }^{40} \mathrm{Ar}-{ }^{39} \mathrm{Ar}$ dating on metamorphic white mica, biotite and fine-grained white mica were carried out.

\subsection{Analytical methods}

\subsubsection{Zircon SIMS U-Pb dating}

Zircon concentrates were extracted using conventional crushing and separation techniques. After set in epoxy resin mounts, mineral grains were polished to their cores. Cathodoluminescence (CL) imaging was performed to observe their internal structure and find suitable positions for spot analyses. Geochronological data were acquired at the State Key Laboratory of Lithospheric Evolution, Institute of Geology and Geophysics, Chinese Academy of Sciences (IGGCAS).

U-Pb zircon dating was conducted on a Cameca IMS-1280HR SIMS following the analytical procedures described by $\mathrm{Li}$ et al. (2009). The primary $\mathrm{O}^{2-}$ ion beam was focused to elliptical spots with the sizes of $20 \mu \mathrm{m} \times 30 \mu \mathrm{m}$. Measured $\mathrm{Pb} / \mathrm{U}$ ratios were calibrated relative to the zircon standard Plešovice (Sláma et al., 2008). Non-radiogenic $\mathrm{Pb}$ was subtracted from the measured $\mathrm{Pb}$ isotopic composition using the measured ${ }^{204} \mathrm{~Pb}$ and the present-day average terrestrial $\mathrm{Pb}$ isotopic composition in the model of (Stacey and Kramers, 1975). U-Pb data were plotted and calculated using the program Isoplot 3.00 (Ludwig, 2003), and age uncertainties are quoted at the 95\% confidence level except for those noted otherwise. Measurements on a second zircon standard Qinghu were interspersed with unknowns to monitor the external uncertainties, and yielded concordia ages of $159.6 \pm 1.6 \mathrm{Ma}(\mathrm{MSWD}=0.28, \mathrm{~N}=6)$, which are identical within errors to the recommended age $(159.5 \pm 0.2 \mathrm{Ma})(\mathrm{Li}$ et al., 2013b).

\subsection{2 ${ }^{40} \mathrm{Ar}-{ }^{39} \mathrm{Ar}$ dating}

Micas were separated from eight micaschist, gneiss, and mylonite samples for ${ }^{40} \mathrm{Ar} /{ }^{39} \mathrm{Ar}$ dating by step-heating technique. Minerals were irradiated and measured in the Ar-Ar Laboratory, School of Earth Sciences of the University of Melbourne. Handpicked grains were cleaned in de-ionized water and acetone. Samples were weighted and loaded into aluminum packets for irradiation. The packets were placed in a silicate glass tube (Can UM\#80), interleaved with packets containing the flux monitor Mount Dromedary Biotite $($ Age $=99.125 \pm 0.076 \mathrm{Ma})($ Phillips et al., 2017). The canister was 
irradiated for $40 \mathrm{MWhr}$ in the CLICIT facility of the Oregon State University TRIGA reactor, USA. The measured isotopic ratios were corrected for system blanks, mass discrimination, and irradiation-induced interference. Plateau and/or total gas ages with $2 \sigma$ uncertainties were calculated and calibrated based on methods proposed by (Lee et al., 2006). Analytical data are presented in Table S2 (Xue et al., 2020), and the age spectra are presented in Figure 11. Argon age plateaus are defined by contiguous gas fractions that together represent more than $50 \%$ of the total ${ }^{39} \mathrm{Ar}$ released from the sample and for which no difference in age can be detected between any two fractions at the $95 \%$ confidence level (Fleck et al., 1997). According to this definition, all argon age spectra in this work, except for sample CX33, do not yield plateau ages (Figure 11). We choose contiguous steps within $95 \%$ confidence close to $50 \%$ of the total ${ }^{39} \mathrm{Ar}$ released (CX6A white mica), or contiguous steps close to $95 \%$ confidence more than $50 \%$ of the total ${ }^{39} \mathrm{Ar}$ released $(\mathrm{CX} 2, \mathrm{CX} 6 \mathrm{~B}, \mathrm{CX} 25, \mathrm{CX} 44$ white mica), to calculate weighted mean ages (Figure 11).

\subsection{Results}

\subsubsection{U-Pb dating on synkinematic Mupi pluton}

Zircons from the Mupi pluton are pink to colorless, 80 to $200 \mu \mathrm{m}$ long with length/width ratios from 2 to 3 . They show well-developed crystal morphologies. CL images of zircons show that most of the zircons have well-developed oscillatory zoning of igneous origin and some grains have an inherited core (Figure 10a). Under guidance of the zircon CL images, analyzed spots were positioned on the oscillatory zircon mantle/margin when there are exist inherited zircon cores. SIMS U-Pb zircon results are listed in Table S1. The SIMS U-Pb dating of the Mupi pluton yields a concordant age of $219.1 \pm 1.7 \mathrm{Ma}(\mathrm{MSWD}=0.99, \mathrm{~N}=15$; Figure $10 \mathrm{~b})$.

\subsection{2 ${ }^{40} \mathrm{Ar}-{ }^{39} \mathrm{Ar}$ dating}

Sample CX44 collected from the northern Northwestern Zone (Figure 12) is micaschist with penetrative SSE-dipping foliation and associated S-plunging lineation related to the $\mathrm{D}_{1 \mathrm{w}}$ top-to-the-N thrusting. The CX44 micaschist contains domains rich in fine-grained white mica and quartz that define the shear foliation (Figures S2a-b). Multi-grain white mica (211-152 $\mu \mathrm{m})$ separated from CX44 yields a weighted mean age of $224.1 \pm 1.7 \mathrm{Ma}$, accounting for $81 \%$ of released ${ }^{39} \mathrm{Ar}$ (Figures $11 \mathrm{a}$ and Table 1 ). 

micaschist involved in the $\mathrm{D}_{1 \mathrm{w}}$ top-to-the-NW thrusting. Shear foliation is defined by aligned fine-grained white mica (Figure $7 \mathrm{~g}$ ). Two aliquots of fine-grained white mica (104-66 $\mu \mathrm{m})$ of CX12A \& CX12B show discordant stair-shaped spectra increasing from $\sim 65-70$ Ma to $\sim 150 \mathrm{Ma}$ and $\sim 120 \mathrm{Ma}$, respectively (Figures $11 \mathrm{~b}-\mathrm{c}$ and Table 1).

Samples CX6 and CX33 (Figure 12), collected from the Inner Metamorphic Core 560 within the Southeastern Zone, are characterized by penetrative NW-dipping foliation and NW-plunging lineation that was involved in $\mathrm{D}_{1 \mathrm{E}}$ top-to-the-SE thrusting. In these two samples, the foliations and associated lineations are defined by white mica (Figures $6 \mathrm{~d}$ and S2g). Two aliquots of white mica $(152-211 \mu \mathrm{m})$ of CX6A and CX6B yield equivalent weighted mean ages of $124 \pm 1.9 \mathrm{Ma}$ and $126.3 \pm 3.3 \mathrm{Ma}$, respectively (Figure 11d-e). Multi-grain white mica $(152-211 \mu \mathrm{m})$ from CX33 yields a plateau age of $148.2 \pm 1.2 \mathrm{Ma}\left(>60 \%\right.$ of the total ${ }^{39} \mathrm{Ar}$; Figure $11 \mathrm{f}$ and Table 1$)$.

Samples CX25 from micaschist of the Xuelongbao complex and CX18, CX19 from gneiss/mylonite of the Pengguan complex (Figures 12) show well-developed NWdipping foliations related to the $\mathrm{D}_{2}$ top-to-the-NW normal faulting (Figures $\mathrm{S} 2 \mathrm{c}-\mathrm{f}$ ). White mica (211-152 $\mu \mathrm{m})$ in CX25 that defines the shear planes (Figures S2e-f) was selected for ${ }^{40} \mathrm{Ar} /{ }^{39} \mathrm{Ar}$ dating. Five steps of sample CX25 with $\sim 80 \%$ released ${ }^{39} \mathrm{Ar}$ yields a weighted mean age of $79.7 \pm 2.7 \mathrm{Ma}$ (Figure 11h). Samples of CX18 and CX19 have stair-shaped spectra, in which ages increase from $\sim 50-60$ Ma to $\sim 110-135 \mathrm{Ma}$ from low- to high-temperature steps (Figure 11i-k and Table 1).

Sample CX2 from the northwest boundary of the Pengguan complex (in a structural position equivalent to the samples CX18 and CX19; Figure 12) was involved in the $\mathrm{D}_{2}$ top-to-the-NW normal faulting (Figures 3 and 9g-i). Multi-grain white mica (211-152 $\mu \mathrm{m})$ from CX2 yields a weighted mean age of $26.23 \pm 0.99 \mathrm{Ma}$ at low- to mediumtemperature steps $\left(>50 \%\right.$ of the total ${ }^{39} \mathrm{Ar}$ released; Figure $11 \mathrm{~g}$ and Table 1$)$.

In the northern Northwestern Zone, the Mupi pluton shows a continuous transition from mylonitic fabrics along the pluton margin to magmatic fabrics in the pluton interior, arguing for its synkinematic emplacement. This deduction is supported by the fact that quartz + feldspar veins parallel to the mylonitic foliation, and feldspar records 
brittle deformation occurred in the presence of residual melt (see details in Section 3.3.3). Thus, the $\mathrm{D}_{1 \mathrm{w}}$ top-to-the-N/NW thrusting is closely related to the emplacement of the Mupi pluton. Our zircon U-Pb ages reveal that the Mupi pluton emplaced at $c a$. $219 \mathrm{Ma}$, therefore place age constraint on the $\mathrm{D}_{1 \mathrm{w}}$ top-to-the-N/NW thrusting at $c a$. $219 \mathrm{Ma}$ (Figure 12).

\subsection{2 ${ }^{40} \mathrm{Ar}-{ }^{39} \mathrm{Ar}$ data interpretation}

All samples show high radiogenic ${ }^{39} \mathrm{Ar}$ and almost all steps are clustered at the horizontal ${ }^{39} \mathrm{Ar} /{ }^{40} \mathrm{Ar}$ axis that does not define a real inverse isochron line (Table S2; Figure S3). Most of the step-ages calculated both by using initial ${ }^{40} \mathrm{Ar} /{ }^{36} \mathrm{Ar}$ of 298.56 (Lee et al., 2006) and from the so-called inverse isochron show nearly no difference (Table S2). Thus, the inverse isochron ages (though identical to their weighted mean ages or plateau ages) and the fake extraneous atmosphere argon are meaningless and will not be further discussed (Figure S3; Table S2).

Concordant white mica ${ }^{40} \mathrm{Ar}-{ }^{39} \mathrm{Ar}$ spectra, such as those yielded by samples of CX44 601 (81.6\% released $\left.{ }^{39} \mathrm{Ar}\right)$, CX6A (49.5\% released $\left.{ }^{39} \mathrm{Ar}\right), \mathrm{CX} 6 \mathrm{~B}\left(52.4 \%\right.$ released $\left.{ }^{39} \mathrm{Ar}\right)$, $602 \mathrm{CX} 33\left(60.1 \%\right.$ released $\left.{ }^{39} \mathrm{Ar}\right), \mathrm{CX} 2\left(53.6 \%\right.$ released $\left.{ }^{39} \mathrm{Ar}\right)$ and CX25 (79.7\% released $603{ }^{39} \mathrm{Ar}$ ), are typical of samples that have remained a closed system since 604 thermal/mylonitic resetting or crystallization (Figures 11a and d-h). Similar rocks to 605 sample CX44 recorded greenschist facies metamorphism under temperatures of 260$606310^{\circ} \mathrm{C}$ (chlorite + white mica multi-equilibrium thermometer; Liu et al., 2008), which 607 is lower than the white mica argon closure temperature of $c a .425{ }^{\circ} \mathrm{C}(100 \mu \mathrm{m}$ 608 grain)(Harrison et al., 2009). Considering that the dated mica grains are strongly 609 deformed by the top-to-the-N/NW thrusting, we, therefore, interpret that the $224.1 \pm$

$6101.7 \mathrm{Ma}$ argon age of CX44 recorded the timing of the white mica recrystallization 611 related to the $\mathrm{D}_{1 \mathrm{~W}}$ thrusting event.

612 Samples of CX6A \& CX6B, and CX33 from the Inner Metamorphic Core, CX2 and 613 CX25 from the mylonite zone along the northwest boundary of the Pengguan and 614 Xuelongbao complexes have been deformed and metamorphosed at temperatures 615 of $>530^{\circ} \mathrm{C}$ (Raman Spectroscopy on Carbonaceous Material; Robert et al., 2010b). 616 These temperatures are higher than the closure temperature $\left(425^{\circ} \mathrm{C}\right)$ of the $c a .100 \mu \mathrm{m}$ 617 radius muscovite grain (Harrison et al., 2009). There is no evidence of any post late 618 Cretaceous to Cenozoic magmatism along the LMTB and its adjacent eastern Songpan619 Ganzi Terrane. Thus, the flattened spectra of CX6A (124 $\pm 1.9 \mathrm{Ma})$, CX6B (126.3 \pm 
621 probably cooling ages when deformation rapidly exhumed those rocks through the ca.

$622425{ }^{\circ} \mathrm{C}$ geothermal depth. These cooling ages, therefore, can represent the timing of 623 deformations. In this scenario, considering samples of CX6A, CX6B and CX33 were 624 involved in top-to-the-SE thrusting, we interpret the dates of $148 \mathrm{Ma}$ and $124 \mathrm{Ma}$ as 625 ages to SE-ward thrusting and rapid exhumation. Samples of CX2 and CX25 collected 626 from the northwest boundary of the Pengguan and Xuelongbao complexes were 627 involved in top-to-the-NW normal faulting, which may imply that the top-to-the-NW 628 normal faulting occurred at $c a .27 \mathrm{Ma}$ along the northwest boundary of the Pengguan 629 complex, and at $c a$. $80 \mathrm{Ma}$ along the northwest boundary of the Xuelongbao complex, 630 respectively.

631 Discordant stair-shaped spectra, such as those observed from the samples of CX12, $632 \mathrm{CX} 18$, and CX19 (Figures 11b-c, i-k), are commonly observed in fine-grained mineral 633 mixes (Tian et al., 2016). Those staircase spectra indicate ${ }^{40} \mathrm{Ar}$ diffusive loss that is 634 possibly related to chemical alteration, a subsequent thermal event disturbance, or 635 argon loss during the late stage mylonitisation (Costa and Maluski, 1988; Lovera et al., 636 1989; West and Lux, 1993). The oldest age of the stair-shaped spectra is a minimum 637 one for the fine-grained white mica closure age (McDougall and Harrison, 1988). 638 Samples of CX12, CX18, and CX19 have been deformed at temperatures $>530^{\circ} \mathrm{C}$ as 639 well (Raman Spectroscopy on Carbonaceous Material; Robert et al., 2010). 640 Considering the size of white mica (104-66 $\mu \mathrm{m})$, the argon-argon system of fine641 grained mica should be completely reset (Harrison et al., 2009). According to the stair642 shaped spectra, samples of CX12A, CX12B, CX18, CX19A, CX19B may have 643 recrystallized or been reset before $146.5 \pm 2.7 \mathrm{Ma}, 119 \pm 1.3 \mathrm{Ma}, 111.1 \pm 0.2 \mathrm{Ma}, 133.7$ $644 \pm 3.3 \mathrm{Ma}$, and 139.3 $\pm 1.1 \mathrm{Ma}$, respectively (Figures $11 \mathrm{~b}-\mathrm{c}, \mathrm{i}-\mathrm{k}$ ). These oldest ages of 645 the stair-shaped spectra possibly resulted from the 148-124 Ma mylonitisation as 646 implied by ${ }^{40} \mathrm{Ar}-{ }^{39} \mathrm{Ar}$ cooling ages of CX6A, CX6B, and CX33.

647 Chemical alteration should have led to a more profound influence on the fine648 grained white mica of CX12, CX18, and CX19 that may result in ${ }^{40} \mathrm{Ar}$ diffusive loss 649 and flattened spectra (Harrison et al., 2009). In this way, considering samples of CX2, 650 CX18, CX19, and CX25 located at the same structural position along the northwest 651 boundary of the Neoproterozoic complexes, we may expect that CX2 and CX25, 652 showing stair-shaped spectrum and CX18, CX19 and presenting flattened spectra, yield 
younger ages, however, it is not the case (Figures $11 \mathrm{~g}-\mathrm{k}$ ). Thus, chemical alteration and related ${ }^{40} \mathrm{Ar}$ diffusive loss may not be the main factor to account for the stair-shaped spectra.

An alternative interpretation may suggest that the youngest age of the stair-shaped spectra gives a maximum age of the thermal overprint or late-stage mylonitisation (Costa and Maluski, 1988; Lovera et al., 1989; West and Lux, 1993). As stated above, no magmatism of late Mesozoic-Cenozoic ages has been reported along the LMTB. Thus, the post-cooling thermal event may not be responsible for the minimum ages of the stair-shaped spectra. The youngest ages in the stair-shaped spectra therefore most likely indicate late-stage mylonitisation after $\sim 60-50$ Ma (Figures $11 \mathrm{i}-\mathrm{k}$ ), which possibly related to the $c a .27 \mathrm{Ma}$ top-to-the-NW faulting along the northwest boundary of the Pengguan complex. It is worth to note that the CX12A and CX12B fine-grained white mica from the Northwestern Zone (Figure 12), far away from the Pengguan complex, show older minimum ages of $64.7 \pm 1.3 \mathrm{Ma}$ and $72.2 \pm 1.4 \mathrm{Ma}$ comparing with the $50 \pm 0.1 \mathrm{Ma}, 59 \pm 0.3 \mathrm{Ma}$, and $58.4 \pm 0.4 \mathrm{Ma}$ of the CX18, CX19A and CX19B (Figures $11 \mathrm{~b}-\mathrm{c}, \mathrm{j}-1$ ), which may suggest that the CX12 has been less affected by the top-to-the-NW normal faulting comparing to the CX18 and CX19.

\section{Discussion}

\subsection{Summary of our newly obtained structural results}

On the basis of detailed structural analyses, a Main Central Boundary and a $\mathrm{D}_{1 \mathrm{w}}$ topto-the-N/NW thrusting in the Northwestern Zone are argued for the first time in the LMTB. The Main Central Boundary corresponds to a major tectonic boundary supported both by field structures and geophysical profile (Jia et al., 2006; Robert et al., 2010b), which divides the LMTB into a Northwestern Zone (part of the Songpan-Ganzi Terrane) to the northwest and a Southeastern Zone to the southeast. The Southeastern Zone is characterized by exclusively NW-dipping foliations and associated $\mathrm{D}_{1 \mathrm{E}}$ top-tothe-SE thrusting, while the Northwestern Zone is characterized by exclusively SEdipping foliations and associated $\mathrm{D}_{1 \mathrm{w}}$ top-to-the-NW thrusting.

This study subdivides the Southeastern Zone of the LMTB into four units based on increasing deformation intensities and metamorphic grades from southeast to northwest, namely the Autochthon, Para-autochthon, Allochthon, and Inner Metamorphic Core. This subdivision pattern is revised from the previous one that divided the LMTB into 
686

687

688

689

690

691

692

693

694

695

696

697

698

699

700

701

702

703

704

705

706

707

708

709

710

711

712

713

714

715

716 3) The ages of the voluminous magmatism intruding the extensively folded Songpan-

717 Ganzi Terrane range between 223 and $200 \mathrm{Ma}$, which postdates the folding in the 718 Songpan-Ganzi Terrane and the top-to-the-SE thrusting of the LMTB (Figure 12)(Xu

an allochthonous sheet thrust southeastwards on top of the autochthonous Sichuan Foreland Basin (Xu et al., 1992; Burchfiel et al., 1995; Worley and Wilson, 1996).

In the Southeastern Zone, a $\mathrm{D}_{2}$ top-to-the-NW normal faulting that cuts the $\mathrm{D}_{1 \mathrm{E}}$ topto-the-SE thrusting is recognized along the northwest boundary of the Pengguan and Xuelongbao complexes.

\subsection{Polyphase deformations along the LMTB}

According to the geometric and kinematic features and overprinting relationship, together with ${ }^{40} \mathrm{Ar}-{ }^{39} \mathrm{Ar}$ and zircon $\mathrm{U}-\mathrm{Pb}$ data, which allow us to draw a polyphase deformation sequence of the LMTB.

\subsubsection{Timing of the $\mathrm{D}_{1}$ main deformation event}

Timing of the $\mathrm{D}_{1 \mathrm{w}}$ top-to-the-N/NW thrusting is firstly constrained by the emplaced timing of the syntectonic Mupi pluton at ca. 219 Ma (Figure 12). Synkinematic recrystallized white mica of sample CX44 that is involved in the top-to-the-N/NW thrusting yields a weighted mean age of $224.1 \pm 1.7 \mathrm{Ma}$, which places a second age constraint on the $\mathrm{D}_{1 \mathrm{w}}$ top-to-the-N/NW thrusting. This newly obtained argon age is consistent with previously published white mica ${ }^{40} \mathrm{Ar}-{ }^{39} \mathrm{Ar}$ ages at ca. 237-202 Ma from the northern Northwestern Zone (Figure 12)(Yan et al., 2011; Yan et al., 2018). The fact that the zircon $\mathrm{U}-\mathrm{Pb}$ age of the Mupi pluton is $c a .5 \mathrm{Ma}$ younger than the synkinematic white mica ${ }^{40} \mathrm{Ar}-{ }^{39} \mathrm{Ar}$ age may suggest the Mupi pluton emplaced during the late phase of the $\mathrm{D}_{1 \mathrm{w}}$ event. Based on the zircon $\mathrm{U}-\mathrm{Pb}$ age of syntectonic Mupi pluton and synkinematic white mica ${ }^{40} \mathrm{Ar}^{39} \mathrm{Ar}$ age, we, therefore, suggest that the $\mathrm{D}_{1 \mathrm{w}}$ top-to-the-N/NW thrusting event occurred at ca. 224-219 Ma.

The $\mathrm{D}_{1 \mathrm{E}}$ top-to-the-SE thrusting within the Southeastern Zone has been constrained in the late Triassic for the following arguments: 1) Field observations and seismic reflection profile revealed that late Jurassic-Cenozoic rocks unconformably overly on intensively folded rocks as young as late Triassic (Figures 2 and 4a-d)(BGMRSP, 1991; Jia et al., 2006); 2) Detailed petrological analyses and in-situ allanite U-Pb dating and biotite ${ }^{40} \mathrm{Ar} /{ }^{39} \mathrm{Ar}$ dating revealed a ca. $204-190$ Ma peak metamorphism in the Inner Metamorphic Core that postdates the $\mathrm{D}_{1 \mathrm{E}}$ event (Airaghi et al., 2017a; 2018a; 2018c); 
et al., 1992; Roger et al., 2004; Harrowfield and Wilson, 2005; Hu et al., 2005; Zhang et al., 2007; de Sigoyer et al., 2014). Thus, the regional $D_{1 \mathrm{E}}$ top-to-the-SE thrusting was at least activated during the late Triassic, together with the contemporary $\mathrm{D}_{1 \mathrm{w}}$ top-tothe-N/NW thrusting recorded within the Northwestern Zone, both of which compose the ca. 224-219 Ma main $\mathrm{D}_{1}$ double-vergent event.

\subsubsection{Timing of the $\mathrm{D}_{2}$ top-to-the-NW normal faulting}

According to the newly obtained ${ }^{40} \mathrm{Ar}-{ }^{39} \mathrm{Ar}$ ages, the timing of the $\mathrm{D}_{2}$ top-to-the-NW normal faulting occurred along the northwest boundary of the Pengguan (ca. $27 \mathrm{Ma}$ ) and Xuelongbao (ca. $80 \mathrm{Ma}$ ) complexes are quite different. The top-to-the-NW/N normal faulting is widespread in an over $300 \mathrm{~km}$ long zone along the northern margins of the Danba and Kangding complexes, and the northwest margins of the Baoxing, 730 Wulong, Xuelongbao, Moutuo, Pengguan, and Jiaoziding complexes (Figure 731 12)(Burchfiel et al., 1995; Xu et al., 2008; Tian et al., 2016; Xue et al., 2017). This belt 732 of top-to-the-NW normal faulting has previously been entitled East Tibet Detachment 733 (Figure 12)(Wang et al., 2012b). Timing of the East Tibet Detachment top-to-the-NW 734 normal faulting is different at different localities. Hames and Burchfiel (1993) reported 735 a top-to-the-NW normal faulting and syntectonic metamorphism at $c a .25 \mathrm{Ma}$ along the northwest Pengguan complex that is in accordance with the $c a .27$ Ma top-to-the-NW normal faulting as indicated by sample CX2 (Figure 12).

Along the northwest boundary of the Wulong complex and north boundary of the 739 Danba complex, the top-to-the-NW/N normal faulting was constrained to $c a$. 81-47 Ma $740 \quad\left({ }^{40} \mathrm{Ar} /{ }^{39} \mathrm{Ar}\right.$ dating on metamorphic biotite and white mica; Figure 12)(Zhou et al., 2008; 741 Tian et al., 2016). This phase of the top-to-the-NW normal faulting is recorded along 742 the northwest boundary of the Xuelongbao complex ( $\mathrm{ca} .80 \mathrm{Ma}^{40} \mathrm{Ar}^{3}{ }^{39} \mathrm{Ar}$ age of sample 743 CX25) as well.

744 A period of the top-to-the-NW/N normal faulting at $c a$. 166-159 Ma was reported 745 at the northwest boundary of the Jiaoziding and Pengguan complexes, and the north 746 boundary of the Danba complex (Figure 12)(Dirks et al., 1994; Zhou et al., 2008; Li, 747 2009). Whereas, younger ages of $c a$. 122-120 Ma related to the top-to-the-N normal 748 faulting at the north boundary of the Danba complex were reported as well (Figure 749 12)(Xu et al., 2008).

750 In summary, the timing of the top-to-the-NW normal faulting of the East Tibet 751 Detachment are scattered at ca. 166-159 Ma (north Danba, northwest Pengguan, 
northwest Jiaoziding), ca. 122-120 Ma (north Danba), ca.81-47 Ma (north Danba,

753 northwest Wulong) and ca. 27-25 Ma (northwest Pengguan; Figure 12). Nonetheless,

754 a process is required to explain these four groups of well-defined argon plateau ages 755 that do not show an age-changing trend in map view (Figure 12). We, therefore, prefer 756 to interpret that the top-to-the-NW/N normal faulting of the East Tibet Detachment was 757 episodically and co-planarly activated at ca. 166-159 Ma, ca. 122-120 Ma, ca. 81-47 758 Ma, and ca. 27-25 Ma (Figure 12). The late-stage activations could partially reset the 759 fine-grained white mica argon system that resulted in stair-shaped spectra yielded by 760 samples of CX18 and CX19 (Figures 11 and 12).

\subsection{Episodic basement-slice-imbrication and amphibolite facies metamorphic rock} exhumation

The Western Sichuan Foreland Basin (WSFB) was formed by loading and subsidence due to the southeastward thrusting of the LMTB along the YingxiuBeichuan Fault and Xiaoguanzi Fault ( $\mathrm{T}_{2}$ in Figure 12)(Chen and Wilson, 1996; Li et al., 2003). Episodic terrestrial deposition in the WSFB from the late Triassic to the present day indicates that the LMTB continued to be tectonically active episodically during the late Triassic to early Jurassic, late Jurassic to early Cretaceous, and late Cretaceous to earliest Paleocene (Figure 12)(Xu et al., 2008; Li et al., 2013c; Tian et al., 2016).

The late Jurassic to early Cretaceous southeastward thrusting of the YingxiuBeichuan Fault and Xiaoguanzi Fault ( $\mathrm{T}_{2}$ in Figure 12), as the southeast boundary Fault of the Pengguan and Baoxing complexes, overlaps the ca. 166-159 Ma and ca. 122$120 \mathrm{Ma}$ top-to-the-NW/N normal faulting along the NW boundary of the Jiaoziding complex and the north boundary of the Danba complex (Figure 12)(Xu et al., 2008; Zhou et al., 2008; Li, 2009). The late Cretaceous-earliest Paleocene southeastward thrusting of the Yingxiu-Beichuan Fault and Xiaoguanzi Fault is also coeval with the top-to-the-NW/N normal faulting along the NW boundary of the Xuelongbao (CX25 in this study) and Wulong (Tian et al., 2016) complexes (Figure 12). Furthermore, both the top-to-the-SE thrusting and top-to-the-NW normal faulting along the southeast and northwest boundaries of the complexes occurred under similar greenschist-facies metamorphic conditions (Airaghi et al., 2017b; Xue et al., 2017). Conjugated kinematics of boundary SE-thrusting and NW-normal faulting characterized by similar 
metamorphic conditions and synchronous timing let us propose that the Xuelongbao,

786 Pengguan, Baoxing and Wulong complexes were episodically imbricated to the 787 southeast as basement-slices during late Jurassic-early Cretaceous and late Cretaceousearliest Paleocene.

Numerical modeling of co-seismic slip vectors $v s$. fault angles indicates that the latest high-angle listric Yingxiu-Beichuan Fault might have facilitated the vertical imbrication of the Pengguan complex with no need of the SE-ward thrusting and loading (Feng et al., 2015). This feature explains the absence of a rejuvenated foreland basin contemporary to the 27-25 Ma basement imbrication. Nevertheless, the 27-25 Ma basement slice imbrication of the Pengguan complex is compatible with its 30-25 Ma fast cooling (Figure 12)(Wang et al., 2012a).

In the map view, two amphibolite facies metamorphic zones wrap the Xuelongbao and Danba complexes (Figure 13a). Both amphibolite facies metamorphic zones reached peak conditions at ca. 210-180 Ma post to the late Triassic orogeny (Figure 12)(Dirks et al., 1994; Huang et al., 2003a; Weller et al., 2013; Airaghi et al., 2018a).

800 Gravity anomaly indicated that the Xuelongbao complex probably extends 801 northeastwards beneath and parallel to the amphibolite facies metamorphic rocks (Xue 802 et al., 2017). Coincidently, the Wenchuan-Xuelongbao and Danba amphibolite facies 803 metamorphic zones experienced rapid exhumation and cooling during the late Jurassic 804 to early Cretaceous (CX12 and CX33 in this work) that is coeval with the 805 aforementioned late Jurassic-early Cretaceous basement-slice-imbrication (Figure 806 13b)(Arne et al., 1997; Huang et al., 2003a; Tian et al., 2016; Airaghi et al., 2018a). 807 Both gravity inversion (Xue et al., 2017) and seismic reflection profiles (Guo et al., 808 2013) revealed a belt of basement-slice hidden right beneath a Mesozoic Laojungou 809 granite (224 $\pm 5 \mathrm{Ma}$; Zhao et al., 2007) within the east Songpan-Ganzi Terrane (Figure 810 13a). The Laojungou granite recorded rapid exhumation and cooling during the late 811 Jurassic to early Cretaceous as well (Figure 13b)(Yuan et al., 1991).

812 Considering the spatial-cooling-imbricating relationships between the Laojungou 813 granite, amphibolite facies metamorphic zones and basement-slices, we interpret that 814 the Laojungou granite and amphibolite facies metamorphic rocks were popped up by a 815 basement-slice-imbrication during the late Jurassic-early Cretaceous. The basement816 slice-imbrication was responsible for localized fast cooling and exhumation of the 817 amphibolite-facies metamorphic rocks. However, the Wenchuan-Xuelongbao 
metamorphic sedimentary cover does not show fast cooling during the late Cretaceousearliest Paleocene and at $c a$. 27-25 Ma comparing to the basement-slice-imbrication (Figure 13b), which needs further work.

\subsection{Mesozoic tectonic evolution of the LMTB}

The Mesozoic tectonic evolution of the LMTB can be summarized as follows without consideration of the top-to-the-N/NW thrusting in the Northwestern Zone. Namely, the Songpan-Ganzi Terrane subducted to the north along the Anymaqen Suture Zone and/or to the southwest along the Jinshajiang Suture Zone, which resulted in the top-to-the-S shearing of the thick Triassic flysch cover along a basal decollement layer (Mattauer et al., 1992; Calassou, 1994) and associated sinistral strike-slip to the southeastward thrusting in the LMTB (Xu et al., 1992; Dirks et al., 1994; Burchfiel et al., 1995; Worley and Wilson, 1996; Roger et al., 2004; Harrowfield and Wilson, 2005). The amphibolite facies metamorphism in the Wenchuan-Xuelongbao area reached the peak pressure of $>11 \pm 2 \mathrm{kbar}$ at $c a$. $200 \mathrm{Ma}$ (Airaghi et al., 2018b) required a sedimentary cover more than $30 \mathrm{~km}$ in thickness. However, high-resolution seismic reflection and gravity modeling profiles revealed a $\sim 20 \mathrm{~km}$ thickness cover of the Songpan-Ganzi Terrane (Guo et al., 2013; Xue et al., 2017) that is far thinner than the required $\sim 30 \mathrm{~km}$ thickness.

In contrast, Sengör (1984) and Luo (1991) regarded the LMTB as an early Mesozoic intracontinental subduction zone but lack details of structural observation. Considering the pervasive top-to-the-N/NW thrusting in the Northwestern Zone and top-to-the-SE thrusting in the Southeastern Zone, we thus prefer an early Mesozoic intracontinental subduction along the LMTB.

In this work, the Main Central Boundary, devoid of ophiolitic rocks separating the Southeastern Zone to the SE from the Northwestern Zone to the NW, does not represent an ophiolitic suture zone, but a tectonic "scar" corresponding to the place where the Yangtze basement was underthrusted. Like the Chenzhou-Linwu Fault in the Xuefengshan Intracontinental Orogen (South China) where the South China Block underthrusted (Chu et al., 2012a; Chu et al., 2012b). Along the LMTB, the underthrusting was coeval with important burial $(>11 \pm 2 \mathrm{kbar})$ and the double-vergent thrusting in both sides of the Main Central Boundary. The basement underthrusting is also supported by the blueschist with intraplate affinity reported along the Qingchuan- 
851 Pingwu Fault (Wei, 1994; Xu et al., 2020). A new tectonic scenario is proposed here 852 (Figure 14). In the pre-middle Triassic times, the Longmenshan area along the western 853 Yangtze margin was a failed rift evidenced by radiolarian chert, abyssal deposits, slump 854 structures (Long, 1991; Luo, 1991; Chang, 2000; Li, 2009) and seismic profile (Jia et 855 al., 2006). Accompany with the pre-middle Triassic rifting, a series of NW-dipping syn856 depositional normal faults developed in the Longmenshan area that dissected the 857 western Yangtze basement to slices, and the lower crust thinned significantly that resulted in a local "weak zone" in the lower crust (Figure 14a).

During the late Triassic, the Yangtze basement underthrusting along the "weak zone" 860 accommodated by inversion of the normal faults, which can be linked to the far-field effect of the Paleotethys' closure (Figure 14b)(Luo, 1991; Chen and Wilson, 1996; Meng et al., 2005; Yan et al., 2019). The sedimentary cover was simultaneously shortened by a top-to-the-SE thrusting and a top-to-the-NW thrusting associated with the main $\mathrm{D}_{1}$ event (Figure 14b). The domain of the top-to-the-SE thrusting in the Southeastern Zone is larger and more extensive than the top-to-the-NW thrusting in the Northwestern Zone. Similar structures were developed in the north Himalaya where a large domain experienced a top-to-the-S thrusting, compared to a small domain with a top-to-the-N thrusting due to the northward subduction of the India plate (Dewey, 1988; Harrison, 1992). We thus favor an NW-ward basement underthrusting along the LMTB (Figure 14b). The large amount of rift rocks transported southeastwards and overlain the autochthonous foreland basin. In addition, a large volume of rocks was underthrusted to crustal depth deeper than $30 \mathrm{~km}$ and metamorphosed, as documented 873 by the $c a$. 210-180 Ma amphibolite-facies metamorphic zone that metamorphosed at a 874 peak pressure of $>11 \pm 2$ kbar (Figure 12)(Weller et al., 2013; Airaghi et al., 2018a; Airaghi et al., 2018b; Airaghi et al., 2018c).

During periods of the late Jurassic-early Cretaceous, late Cretaceous-earliest Paleogene, the accretion of Gondwana-derived Terranes to the southern Eurasia plate had resulted in episodic compression in the Longmenshan area (Dewey, 1988; Xu et

$880105 \mathrm{Ma}$ compression resulted from the westward subduction of the Paleo-Pacific plate 881 subduction (Chu et al., 2019). Under the regional episodic compression, basement882 slices represented by the Neoproterozoic complexes along the weak zone of the 883 Yangtze Block, including the Xuelongbao, Moutuo, and Danba complexes, 
episodically imbricated southeastwards along the inherited faults. Basement-sliceimbrication then exhumed the basement complexes and the amphibolite facies metamorphic rocks as documented by the synchronously fast cooling of the metasediments and the basement complexes (Figures 12 and 14d)(Yuan et al., 1991; Arne et al., 1997; Huang et al., 2003b; Weller et al., 2013; Tian et al., 2016). Basement-sliceimbrication also reworked the late Triassic allochthonous-autochthonous LMTB into four subdivisions (Figure 14d).

\section{Conclusions}

Based on structural analysis and previous geophysical profile, we have delineated a Main Central Boundary that separates the Longmenshan Thrust Belt into a Southeastern Zone to the southeast and a Northwestern Zone to the northwest.

On the basis of different lithologies, increasing strain intensity and metamorphic grade, the Southeastern Zone is revised into four subdivisions, namely, the Autochthon, Para-autochthon, Allochthon, and Inner Metamorphic Core.

The detailed structural analysis allows us recognizing the multiphase deformation of the LMTB. A main $\mathrm{D}_{1}$ double-vergent thrusting event, characterized by the $\mathrm{D}_{1 \mathrm{E}}$ top-tothe-SE thrusting in the Southeastern Zone and the $\mathrm{D}_{1 \mathrm{w}}$ top-to-the-NW/N thrusting in the Northwestern Zone, has been recognized. The $\mathrm{D}_{1 \mathrm{E}}$ and $\mathrm{D}_{1 \mathrm{~W}}$ events were synchronously occurred corresponding to a late Triassic intracontinental underthrusting along a "weak zone" of the LMTB. A $\mathrm{D}_{2}$ top-to-the-NW normal faulting that cuts the $\mathrm{D}_{1 \mathrm{E}}$ top-to-the-SE thrusting has been recognized along the NW boundary of the basement complexes in the Southeastern Zone.

Geochronological constraints obtained from this study and the previously published ones indicate that the main $\mathrm{D}_{1}$ event occurred at $c a$. 224-219 Ma and the $\mathrm{D}_{2}$ was episodically activated at $c a$. 166-160 Ma, 141-120 Ma, 81-47 Ma, and 27-25 Ma. The episodically and synchronously activated top-to-the-NW normal faulting and top-tothe-SE thrusting along the northwest and SE boundaries of the basement complexes let us propose that the basement-slices episodically imbricated to the SE during the late Jurassic-early Cretaceous and late Cretaceous-earliest Paleocene. The basement-slice imbrication exhumed the $\mathrm{D}_{1}$-related amphibolite facies rocks to the subaerial and reworked allochthonous-autochthonous LMTB into a four subdivision one. 


\section{Acknowledgement}

918 This work is supported by the National Nature Science Foundation of China 919 (91855212, 91755205 and 41802219) and the National Key R\&D Program of China 920 (Grant Numbers 2016YFC0600401, 2016YFC0600102) as well as French LABEX 921 VOLTAIRE (ANR-10-LABX-100-01), and EQUIPEX PLANET (ANR-11-EQPX922 0036). Two anonymous reviewers are sincerely thanked for their elaborative reviews 923 and pertinent comments. The geochronological data including SIMS U-Pb dating on 924 zircons (Table S1) and ${ }^{40} \mathrm{Ar} /{ }^{39} \mathrm{Ar}$ dating on micas (Table S2) for this paper are available 925 in the supplementary materials.

926

\section{Figure captions}

Figure 1. (a) Simplified tectonic sketch of China. QLDB: Qingling-Dabie Orogenic Belt; EKLANMQS: East Kunlun-Anymaqen Suture Zone; JSZ: Jinshajiang Suture Zone; SGT: Songpan-Ganzi

930 Terrane; LMTB: Longmenshan Thrust Belt; ICB: Indochina Block; (b) Simplified geological map of the 931 Longmenshan Thrust Belt, modified after BGMRSP (1991), Burchfiel et al. (1995) and Xu et al. (2008). $932 \mathrm{~T}_{1}$ : Anxian-Guanxian Fault; $\mathrm{T}_{2}$ : Yingxiu-Beichuan Fault; $\mathrm{T}_{3}$ : Wenchuan-Maoxian Fault; $\mathrm{T}_{4}$ : 933 Qingchuan-Pingwu Fault; JZD: Jiaoziding complex; PG: Pengguan complex; XLB: Xuelongbao 934 complex; BX: Baoxing complex; KD: Kangding complex; DB: Danba complex; MT: Moutuo complex; 935 WL: Wulong complex; RLG: Rilonguan granite; LJG: Laojungou granite. Figure 2. Geological map of the north and middle parts of the LMTB and its adjacent area, modified after BGMRSP (1991) and Xu et al. (2008). MP: Mupi pluton. Symbols and acronyms are the same as in Figure 1.

Figure 3. (a) Structural division, field elements including foliation, lineation, and kinematics of the LMTB. (b-d) $\pi$-circle projection of the bedding $\left(\mathrm{S}_{0}\right)$ in the Para-autochthon from south to north. All field elements are shown in a lower hemisphere equal-area projection. Symbols and acronyms are the same as in Figure 1.

Figure 4. (a-d) Geological cross-sections perpendicular to the LMTB. Purple solid lines represent the foliations attitude (Locations are marked in Figure 2). Subaerial structures of these cross-sections are based on our field mapping and the deep structures are based on seismic reflection data of Jia et al. (2006) and Guo et al. (2013). The black dashed lines represent speculated folds. (e) Flower structure revealed 
by the seismic reflection profile processed by Jia et al. (2006)(Location is marked in Figure 4d). MCB:

951 Main Central Boundary; AGF: Anxian-Guanxian Fault; YBF: Yingxiu-Beichuan Fault; WMF:

952 Wenchuan-Maoxian Fault; QCF: Qingchuan-Pingwu Fault. Other symbols and acronyms are the same 953 as in Figure 1

Figure 5. Rock characteristics and deformation style of the Main Central Boundary. (a) Intensely 956 deformed argillaceous limestone characterized by a vertical foliation [ $\left.31^{\circ} 34.833^{\prime} \mathrm{N}, 103^{\circ} 24.041^{\prime} \mathrm{E}\right]$. (b) Graphite-bearing pelite was intensely foliated to shale with vertical attitude $\left[31^{\circ} 35.916^{\prime} \mathrm{N}, 103^{\circ} 24.008^{\prime}\right.$ E]. (c) Foliated thin-bedded limestone and quartz ribbon interlayer and rootless intra-folial folds coexist 959 with vertical foliation [31 $\left.48.403^{\prime} \mathrm{N}, 103^{\circ} 44.080^{\prime} \mathrm{E}\right]$. Rootless folds in figures b-c implying significant 960 shortening. Locations are presented in Figure 3a.

Figure 6. Structural features related to the Main Deformation $\left(\mathrm{D}_{1 \mathrm{E}}\right)$ in the Southeastern Zone. In the

963 Inner Metamorphic Core: (a) Lineation formed by aligned biotite plunging N335 by $30^{\circ}$ on the S964 dipping foliation $\left[31^{\circ} 30.359^{\prime} \mathrm{N}, 103^{\circ} 34.123^{\prime} \mathrm{E}\right]$. (b) Asymmetric pyrite pressure shadow indicating a 965 top-to-the-SE thrusting [31 $42.210^{\prime} \mathrm{N}, 103^{\circ} 51.067^{\prime}$ E]. (c) Sigma-shaped feldspar porphyroclast in

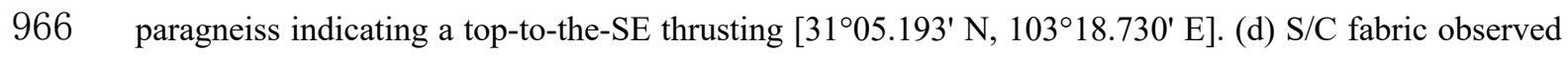
under Cross Polarized Light (CPL) indicating a top-to-the-SE thrusting. In the Allochthon: (e) Sigmoid 968 pelitic lens and "cold” S/C structures developed in the Neoproterozoic Huangshuihe Group suggesting a 969 to the top-to-the-SE thrusting [31 $16.195^{\prime} \mathrm{N}, 103^{\circ} 46.747^{\prime}$ E]. (f) Sigma-shaped sandy lens in Silurian 970 pelitic schist within the nappe indicating a top-to-the-SE thrusting [ $\left.32^{\circ} 04.577^{\prime} \mathrm{N}, 104^{\circ} 40.599^{\prime} \mathrm{E}\right]$. (g) At 971 the rear of the klippe, thick-bedded limestone thrust to the SE along an NW-dipping reverse fault $972\left[31^{\circ} 11.530^{\prime} \mathrm{N}, 103^{\circ} 45.929^{\prime}\right.$ E]. In the Para-autochthon: (h) Sigmoid lens and "cold" S/C fabrics 973 indicating a top-to-the-SE thrusting [30 $\left.55.403^{\prime} \mathrm{N}, 103^{\circ} 20.495^{\prime} \mathrm{E}\right]$. Figure locations are marked in Figure 974 3a. $\mathrm{X}$ and $\mathrm{Z}$ axes are marked on the figures. Mineral abbreviations are after Kretz (1983).

976 Figure 7. Structural features related to the Main Deformation $\left(\mathrm{D}_{1 \mathrm{w}}\right)$ in the Northwestern Zone. In the 977 northern Northwestern Zone: (a) Aligned calcite, fine-grained white mica, and oxide-pods define 978 lineation plunging to the south on the S-dipping foliation [32 $\left.30.892^{\prime} \mathrm{N}, 104^{\circ} 08.178^{\prime} \mathrm{E}\right]$. (b) Sigma979 shaped pebbles in a meta-conglomerate indicating a top-to-the- $\mathrm{N}$ sense of shear $\left[32^{\circ} 53.562^{\prime} \mathrm{N}\right.$, $980105^{\circ} 04.820^{\prime} \mathrm{E}$. (c) Deflected quartz ribbon observed under CPL indicating a top-to-the-N thrusting. (d) 981 Asymmetric feldspar porphyroclast wrapped by deflected white mica suggesting a top-to-the-N thrusting. 982 (e) Northward verging chevron fold associated with meter-scale reverse fault indicating a top-to-the-N 
thrusting [ $\left.32^{\circ} 25.219^{\prime} \mathrm{N}, 104^{\circ} 31.513^{\prime} \mathrm{E}\right]$. (f) Bedding depicted by compositional banding showing an Nverging fold, and bedding to sub-parallel to the foliation in the limbs [32 $\left.228.591^{\prime} \mathrm{N}, 104^{\circ} 26.763^{\prime} \mathrm{E}\right]$. In the southern Northwestern Zone: (g) Asymmetric garnet pseudomorph pressure shadow suggesting a top-to-the-NW thrusting. (h) Hundred-meter scale chevron fold verging to the NW indicating a top-tothe-NW thrusting [ $\left.31^{\circ} 33.912^{\prime} \mathrm{N}, 103^{\circ} 16.680^{\prime} \mathrm{E}\right]$. Figure locations are marked in Figure 3a. $\mathrm{X}$ and $\mathrm{Z}$ axes are marked on the figures. Mineral abbreviations are after Kretz (1983).

Figure 8. Features of the syn-tectonic Mupi pluton in the Northwestern Zone $\left[32^{\circ} 31.445^{\prime} \mathrm{N}, 104^{\circ} 32.456^{\prime}\right.$ E]. (a) Magmatic fabric of the Mupi pluton with euhedral feldspar randomly distributed, about 30 meters north to the south margin of the Mupi pluton. (b) Quartz + feldspar veins parallel to the shear foliation, about 10-15 meters north to the pluton south margin. (c) Strong mylonitisation at the south margin of the pluton shares similar structural geometry and kinematics with the country rock. (d) Asymmetric feldspar porphyroclasts, synthetic offset of feldspar fragments along shear band in XZ plane indicating a top-tothe-N thrusting. (c) Panorama of thin section under CPL of the Mupi pluton, the feldspar brittle cracks (marked by red arrow) infilled by quartz subparallel to the shear foliation. $\mathrm{X}$ and $\mathrm{Z}$ axes are marked on the figures. Figure locations are marked in Figure 3a. Mineral abbreviations are after Kretz (1983).

Figure 9. Structural features related to the top-to-the-NW normal faulting along the northwest boundary of the Neoproterozoic complexes. (a) At the northwest boundary of the Xuelongbao complex, sigmoid feldspar phenocrysts associated with S/C fabric indicating a top-to-the-NW normal faulting [31 ${ }^{\circ} 19.683^{\prime}$ N, $103^{\circ} 23.874^{\prime}$ E]. At the northwest boundary of the Pengguan complex: (b) Granitic mylonite having

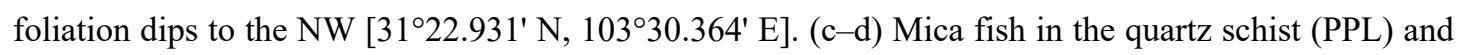
$\sigma$-type porphyroclast (CPL) wrapped by deflected micas indicating a top-to-the-NW normal faulting. (e)

1006 Shear-band (white dashed line) distributes from the upper-right corner to the lower-left corner that cuts 1007 the whole thin section indicate a top-to-the-NW normal faulting, CPL. Sigmoid porphyroclast (e), 1008 incipient shear band inclining to the SE (f), and white mica shear-band fabric (g) indicate a top-to-the1009 SE thrusting related to $\mathrm{D}_{1 \mathrm{E}}$. All of them are cut by the white shear band related to the $\mathrm{D}_{2}$ top-to-the-NW 1010 normal faulting, CPL. Locations are marked in Figure 3a. $\mathrm{X}$ and $\mathrm{Z}$ axes are marked on the figures. 1011 Mineral abbreviations are after Kretz (1983).

1013 Figure 10. (a) CL images of the representative zircons from the Mupi pluton. The scale bar represents $1014100 \mu \mathrm{m}$. (b) SIMS U-Pb Concordia diagram of zircons of the syntectonic Mupi pluton. 
Figure $11 .{ }^{40} \mathrm{Ar}-{ }^{39} \mathrm{Ar}$ age spectra of the dated samples. We carried out a two-aliquot analysis of micas from CX6, CX12, and CX19 to exclude the influence of occasional deviation on the stair-case age spectrum, and the two-aliquot results are labeled with the suffix of A and B (eg., CX6A, CX6B, CX12A, CX12B, CX19A, CX19B). Inverse isochron diagrams are presented in Figure S3. ${ }^{40} \mathrm{Ar}^{-39}$ calculation results are

1021 summarized in Table 1, and detailed step-heating results are presented in the supporting information 1022 Table S2.

Figure 12. Geochronological constraints compiled from published and this study. Ages are shown by the method used to determine the age $(\mathrm{A}=\mathrm{Ar} / \mathrm{Ar} ; \mathrm{K}=\mathrm{K} / \mathrm{Ar} ; \mathrm{U}=\mathrm{U} / \mathrm{Pb} ; \mathrm{F}=$ Fission track $)$ and mineral used $(\mathrm{Am}=$ Amphibole; $\mathrm{B}=$ biotite; $\mathrm{M}=$ Muscovite; $\mathrm{Z}=$ zircon; $\mathrm{Mn}=$ monazite; $\mathrm{I}=$ illite; $\mathrm{S}=$ Sericite; $\mathrm{Wm}$ = white mica). 1. Li (2009); 2. Yan et al. (2018); 3. Yan et al. (2011); 4. Arne et al. (1997); 5. Airaghi et al. (2017b); 6. Airaghi et al. (2018a); 7. Airaghi et al. (2018b); 8. Airaghi et al. (2018c); 9. Zheng et al. (2016); 10. Yan et al. (2008); 11. Zheng et al. (2014); 12. Tian et al. (2016); 13. Huang et al. (2003a);

1030 14. Weller et al. (2013); 15. Xu et al. (2008); 16. Zhou et al. (2008); 17. Wallis et al. (2003); 18. Zhou et 1031 al. (2002); 19. Xia (1993); 20. Xu et al. (1992); 21. Yuan et al. (1991); 22. Hu et al. (2005); 23. Zhao 1032 (2007); 24. Kirby et al. (2002); 25. Roger et al. (2004); 26. Zhang et al. (2006a); 27. Yuan et al. (2010); 28. BGMRSP (1991); 29. Li et al. (2013c); 30. Wang et al. (2012a). 31. Hames and Burchfiel (1993). Symbols and acronyms are the same as in Figure 2.

Figure 13. (a) Spatial relationship between the amphibolite facies metamorphic zones and the basement complexes along the peripheries of the Songpan-Ganzi Terrane. Isograd lines are presented in color dashed lines accompany relating mineral abbreviations. Mineral abbreviations are after Kretz (1983) except Liq representing the magmatic zone. Symbols and acronyms are the same as in Figure 12. (b)

1040 Compiled cooling histories for the Wenchuan-Xuelongbao amphibolite facies metamorphic belt 1041 (WXAB, bold dashed line)(Airaghi et al., 2018a), the Danba amphibolite facies metamorphic belt (DBAB), and migmatite zone (DBM, thin dashed line)(Huang et al., 2003a), and the Mesozoic

1043 Laojungou granite (LJG, bold gray line)(Yuan et al., 1991). Gray frames show the three episodes of 1044 basement-slice-imbrication at late Jurassic-early Cretaceous, late Cretaceous-Earliest Paleocene, $c a$. 1045 27-25 Ma. The Wenchuan-Xuelongbao and the Danba amphibolite facies metamorphic belt and the 1046 Laojungou granite experienced a rapid exhumation and cooling during the late Jurassic to the late Cretaceous, and 27-25 Ma. 
Figure 14. A possible Mesozoic tectonic evolutionary scenario of the LMTB and adjacent area. (a) Premiddle Triassic rifting of the Yangtze Block resulted in crustal thinning and a potential "weak zone" in the future Longmenshan area. (b) During the late Triassic, NW-ward Yangtze basement underthrusting along the "weak zone" resulted in extensive shortening, inversion of syn-depositional normal Fault. The sedimentary rocks were buried to a crustal depth deeper than $30 \mathrm{~km}$. NW- and SE-ward thrusting, and associated nappe belt formed at this time. (c) During the late Triassic to early Jurassic, the underthrusted rocks were metamorphosed. Gradient color from green to dark blue in the Inner Metamorphic Core represents show the low- to high-metamorphic grade. (d) late Jurassic-Miocene, basement-slice episodically imbricated to the SE that exhumed the amphibolite facies metamorphic rocks to the subaerial and reworked the LMTB. Symbols and acronyms are the same as in Figure 2.

Table 1. Summary of ${ }^{40} \mathrm{Ar}-{ }^{39} \mathrm{Ar}$ dating results

\section{References}

Airaghi, L., Janots, E., Lanari, P., de Sigoyer, J., and Magnin, V., 2018a, Allanite petrochronology in fresh and retrogressed garnet-biotite metapelites from the Longmen Shan (eastern Tibet): Journal of Petrology, p. egy109-egy109, https://doi.org/10.1093/petrology/egy109.

Airaghi, L., Lanari, P., de Sigoyer, J., and Guillot, S., 2017a, Microstructural vs compositional preservation and pseudomorphic replacement of muscovite in deformed metapelites from the Longmen Shan (Sichuan, China): Lithos, v. 282283, p. 262-280, https://doi.org/10.1016/j.lithos.2017.03.013.

Airaghi, L., Sigoyer, J., Guillot, S., Robert, A., Warren, C. J., and Deldicque, D., 2018b, The Mesozoic along-strike tectono-metamorphic segmentation of Longmen Shan (eastern Tibetan plateau): Tectonics, v. 37, p. 4655-4678, https://doi.org/10.1029/2018TC005005. Tan, X., 2017b, Total exhumation across the Beichuan fault in the Longmen Shan (eastern Tibetan plateau, China): constraints from petrology and thermobarometry: Journal of Asian Earth Sciences, https://doi.org/10.1016/j.jseaes.2017.04.003. of dissolution/reprecipitation reactions on metamorphic greenschist to 

amphibolite facies mica 40Ar/39Ar ages in the Longmen Shan (eastern Tibet): Journal of Metamorphic Geology, v. 36, no. 7, p. 933-958, https://doi.org/10.1111/jmg.12420.

Arne, D., Worley, B., Wilson, C., Chen, S. F., Foster, D., Luo, Z. L., Liu, S. G., and Dirks, P., 1997, Differential exhumation in response to episodic thrusting along the eastern margin of the Tibetan Plateau: tectonophysics, v. 280, no. 3, p. 239256, https://doi.org/10.1016/S0040-1951(97)00040-1.

BGMRSP, 1991, Regional geology of Sichuan Province, Beijing, Geological Publishing House, 730 p.:

Billerot, A., Duchene, S., Vanderhaeghe, O., and de Sigoyer, J., 2017, Gneiss domes of the Danba Metamorphic Complex, Songpan Ganze, eastern Tibet: Journal of $\begin{array}{lllll}\text { Asian } & \text { Earth } & \text { Sciences, } & \text { v. }\end{array}$ https://doi.org/10.1016/j.jseaes.2017.03.006.

Burchfiel, B. C., Chen, Z., Liu, Y., and Royden, L. H., 1995, Tectonics of the Longmen Shan and Adjacent Regions, Central China: International Geology Review, v. 37, no. 8, p. 661-735, https://doi.org/10.1080/00206819509465424.

Burchfiel, B. C., Royden, L. H., van der Hilst, R. D., Hager, B. H., Chen, Z., King, R. W., Li, C., Lü, J., Yao, H., and Kirby, E., 2008, A geological and geophysical context for the Wenchuan earthquake of 12 May 2008, Sichuan, People's Republic of China: GSA Today, v. 18, no. 7, p. 4-11, https://doi.org/10.1130/gsatg18a.1.

Calassou, S., 1994, Etude tectonique d'une chaîne de décollement. A- Tectonique triasique et tertiaire de la chaîne de Songpan Garzê(Est Tibet). B- Géométrie et cinématique des déformations dans les prismes d'accrétion sédimentaire: Modélisation analogique.

Chang, E. Z., 2000, Geology and Tectonics of the Songpan-Ganzi Fold Belt, Southwestern China: International Geology Review, v. 42, no. 9, p. 813-831, https://doi.org/10.1080/00206810009465113.

Chen, S., and Wilson, C. J. K., 1996, Emplacement of the Longmen Shan Thrust-Nappe Belt along the eastern margin of the Tibetan Plateau: Journal of Structural Geology, v. 18, no. 4, p. 413-429. (In Chinese with english abstract)

Chen, S., Wilson, C. J. L., Luo, Z., and Deng, Q., 1994, The evolution of the Western Sichuan Foreland Basin, southwestern China: Journal of Asian Earth Sciences, 
v. 10, no. 94, p. 159-168, https://doi.org/10.1016/0743-9547(94)90016-7.

Chen, S., Wilson, C. J. L., and Worley, B. A., 1995, Tectonic transition from the Songpan-Garzê Fold Belt to the Sichuan Basin, south-western China: Basin Research, v. 7, no. 3, p. 235-253, https://doi.org/10.1111/j.13652117.1995.tb00108.x.

Chu, Y., Faure, M., Lin, W., and Wang, Q., 2012a, Early Mesozoic tectonics of the South China block: Insights from the Xuefengshan intracontinental orogen: Journal of Asian Earth Sciences, v. 61, p. 199-220, https://doi.org/10.1016/j.jseaes.2012.09.029.

Chu, Y., Faure, M., Lin, W., Wang, Q., and Ji, W., 2012b, Tectonics of the Middle Triassic intracontinental Xuefengshan Belt, South China: new insights from structural and chronological constraints on the basal décollement zone: International Journal of Earth Sciences, v. 101, no. 8, p. 2125-2150, https://doi.org/10.1007/s00531-012-0780-5.

Chu, Y., Lin, W., Faure, M., Xue, Z., Ji, W., and Feng, Z., 2019, Cretaceous Episodic Extension in the South China Block, East Asia: Evidence From the Yuechengling Massif of Central South China: Tectonics, v. 38, no. 10, p. 36753702, https://doi.org/10.1029/2019tc005516.

Clark, M. K., and Royden, L. H., 2000, Topographic ooze: Building the eastern margin of Tibet by lower crustal flow: Geology, v. 28, no. 8, p. 703-706, https://doi.org/10.1130/0091-7613.

Costa, and Maluski, 1988, Use of the 40Ar-39Ar stepwise heating method for dating mylonite zones: An example from the St. Barth616my Massif (North Pyrenees, France). Chemical Geology, v. 72, no. 2, p. 127-144, https://doi.org/10.1016/0168-9622(88)90061-9.

de Sigoyer, J., Vanderhaeghe, O., Duchêne, S., and Billerot, A., 2014, Generation and emplacement of Triassic granitoids within the Songpan Ganze accretionaryorogenic wedge in a context of slab retreat accommodated by tear faulting, Eastern Tibetan plateau, China: Journal of Asian Earth Sciences, v. 88, p. 192216, https://doi.org/10.1016/j.jseaes.2014.01.010.

Dewey, J. F., 1988, The Tectonic Evolution of the Tibetan Plateau: Philosophical Transactions of the Royal Society of London A Mathematical Physical \& Engineering Sciences, v. 327, no. 1594, p. 379-413, 
Dirks, P., Wilson, C., Chen, S., Luo, Z., and Liu, S., 1994, Tectonic evolution of the NE margin of the Tibetan Plateau; evidence from the central Longmen Mountains, Sichuan Province, China: Journal of Southeast Asian Earth Sciences, v. 9, no. 1, p. 181-192, https://doi.org/10.1016/0743-9547(94)90074-4.

Druschke, P. A., and Wang, T., 2006, Stratigraphic and UPb SHRIMP Detrital Zircon Evidence for a Neoproterozoic Continental Arc, Central China: Rodinia Implications: Journal of Geology, v. 114, no. 5, p. 627-636.

Enkelmann, E., Weislogel, A., Ratschbacher, L., Eide, E., Renno, A., and Wooden, J., 2007, How was the Triassic Songpan-Ganzi basin filled? A provenance study: Tectonics, v. 26, no. 4, https://doi.org/10.1029/2006TC002078.

Feng, S., Zhang, P., Liu, B., Wang, M., Zhu, S., Ran, Y., Wang, W., Zhang, Z., Zheng, W., and Zheng, D., 2015, Deep crustal deformation of the Longmen Shan, eastern margin of the Tibetan Plateau, from seismic reflection survey and finite

Fleck, R. J., Sutter, J. F., and Elliot, D. H., 1997, Interpretation of discordant 40Ar/39Ar element modelling: Journal of Geophysical Research: Solid Earth, v. 121, p. age-spectra of mesozoic tholeiites from antarctica: Geochimica Et Cosmochimica Acta, v. 41, no. 1, p. 15-32, https://doi.org/10.1016/00167037(77)90184-3.

Guo, X., Gao, R., Randy Keller, G., Xu, X., Wang, H., and Li, W., 2013, Imaging the crustal structure beneath the eastern Tibetan Plateau and implications for the uplift of the Longmen Shan range: Earth and Planetary Science Letters, v. 379, p. 72-80, https://doi.org/10.1016/j.eps1.2013.08.005.

Hames, W. E., and Burchfiel, B. C., 1993, Laser 40Ar/39Ar dating of Cenozoic, greenschist-facies shear zones, Longmen Shan, China: Geological Society of America, v. 25, no. 6, p. A-118, https://doi.org/10.1016/0012-821X(94)00079$\underline{4}$.

Harrison, T. M., 1992, Raising Tibet: Science, v. 255, no. 5052, p. 1663-1670, https://doi.org/doi: 10.1126/science.55.5052.1663.

Harrison, T. M., Célérier, J., Aikman, A. B., Hermann, J., and Heizler, M. T., 2009, Diffusion of 40Ar in muscovite: Geochimica Et Cosmochimica Acta, v. 73, no. 4, p. 1039-1051, https://doi.org/https://doi.org/10.1016/j.gca.2008.09.038. 
Harrowfield, M. J., and Wilson, C. J. L., 2005, Indosinian deformation of the Songpan Garze Fold Belt, northeast Tibetan Plateau: Journal of Structural Geology, v. 27, no. 1, p. 101-117, https://doi.org/10.1016/j.jsg.2004.06.010.

Hu, J., Meng, Q., Shi, Y., and Qu, H., 2005, SHRIMP U-Pb dating of zircons from granitoid bodies in the Songpan-Ganzi terrane and its implications: Acta Petrologica Sinica, v. 21, no. 3, p. 867-880. (In Chinese with english abstract)

Huang, M., Maas, R., Buick, I. S., and Williams, I. S., 2003a, Crustal response to continental collisions between the Tibet, Indian, South China and North China Blocks: geochronological constraints from the Songpan-Garzê Orogenic Belt, western China: Journal of Metamorphic Geology, v. 21, no. 3, p. 223-240, https://doi.org/10.1046/j.1525-1314.2003.00438.x.

Huang, M. H., Buick, I. S., Hou, L. W., Huang, M. H., and Hou, L. W., 2003b, Tectonometamorphic evolution of the eastern Tibet plateau: Evidence from the central Songpan-Garze orogenic belt, western China: Journal of Petrology, v. 44, no. 2, p. 255-278, https://doi.org/10.1093/petrology/44.2.255.

Hubbard, J., and Shaw, J. H., 2009, Uplift of the Longmen Shan and Tibetan plateau, and the 2008 Wenchuan $(M=7.9)$ earthquake: Nature, v. 458, no. 7235, p. 194197, https://doi.org/10.1038/nature07837.

Jia, D., Wei, G., Chen, Z., Li, B., Zeng, Q., and Yang, G., 2006, Longmen Shan foldthrust belt and its relation to the western Sichuan Basin in central China: New insights from hydrocarbon exploration: AAPG bulletin, v. 90, no. 9, p. 14251447, https://doi.org/10.1306/03230605076.

Kirby, E., Reiners, P. W., Krol, M. A., Whipple, K. X., Hodges, K. V., Farley, K. A., Tang, W., and Chen, Z., 2002, Late Cenozoic evolution of the eastern margin of the Tibetan Plateau: Inferences from 40Ar/39Ar and (U - Th)/He thermochronology: Tectonics, v. 21, no. 1, p. 1-1-1-20, https://doi.org/10.1029/2000TC001246.

Kretz, R., 1983, Symbols for rock-forming minerals: Amer Miner, v. 68, no. 1, p. 277 279, https://doi.org/10.1016/0040-1951(84)90122-7.

Lee, J.-Y., Marti, K., Severinghaus, J. P., Kawamura, K., Yoo, H.-S., Lee, J. B., and Kim, J. S., 2006, A redetermination of the isotopic abundances of atmospheric Ar: Geochimica et Cosmochimica Acta, v. 70, no. 17, p. 4507-4512, https://doi.org/10.1016/j.gca.2006.06.1563. 
Li, H., Wang, H., Xu, Z., Si, J., Pei, J., Li, T., Huang, Y., Song, S.-R., Kuo, L.-W., Sun, Z., Chevalier, M.-L., and Liu, D., 2013a, Characteristics of the fault-related rocks, fault zones and the principal slip zone in the Wenchuan Earthquake Fault Scientific Drilling Project Hole-1 (WFSD-1): Tectonophysics, v. 584, p. 23-42, https://doi.org/10.1016/j.tecto.2012.08.021.

Li, H., Wang, H., Yang, G., Xu, Z., Li, T., Si, J., Sun, Z., Huang, Y., Chevalier, M.-L., Zhang, W., and Zhang, J., 2015, Lithological and structural characterization of the Longmen Shan fault belt from the 3rd hole of the Wenchuan Earthquake Fault Scientific Drilling project (WFSD-3): International Journal of Earth Sciences, https://doi.org/10.1007/s00531-015-1285-9.

Li, X. H., Liu, Y., Li, Q. L., Guo, C. H., and Chamberlain, K. R., 2009, Precise determination of Phanerozoic zircon $\mathrm{Pb} / \mathrm{Pb}$ age by multicollector SIMS without external standardization: Geochemistry, Geophysics, Geosystems, v. 10, no. 4, https://doi.org/10.1029/2009gc002400.

Li, X. H., Tang, G. Q., Gong, B., Yang, Y. H., Hou, K. J., Hu, Z. C., Li, Q. L., Liu, Y., and Li, W. X., 2013b, Qinghu zircon: A working reference for microbeam analysis of $\mathrm{U}-\mathrm{Pb}$ age and $\mathrm{Hf}$ and $\mathrm{O}$ isotopes: Chinese Science Bulletin, v. 58, no. 36, p. 4647-4654, https://doi.org/10.1007/s11434-013-5932-X.

Li, Y., Allen, P. A., Densmore, A. L., and Xu, Q., 2003, Evolution of the Longmen Shan foreland basin (western Sichuan, China) during the Late Triassic Indosinian orogeny: Basin Research, v. 15, no. 1, p. 117-138, https://doi.org/10.1046/j.1365-2117.2003.00197.x.

Li, Y., Su, D., Zhou, R., Li, H., Densmore, A. L., Yan, L., and Yan, Z., 2013c, Episodic orogeny deduced from coeval sedimentary sequences in the foreland basin and its implication for uplift process of Longmen Mountain, China: Journal of Mountain Science, v. 10, no. 1, p. 29-42, https://doi.org/10.1007/s11629-013$\underline{2238-Z}$.

Li, Z., 2009, Composition, structural characteristics and evolution of backLongmenshan orogen (north section) in the northwest margin of Yangtze block [Doctoral thesis: Chang'an University, $211 \mathrm{p}$.

Lin, A., Rao, G., and Yan, B., 2014, Structural analysis of the right-lateral strike-slip Qingchuan fault, northeastern segment of the Longmen Shan thrust belt, central China: Journal of Structural Geology, v. 68, p. 227-244, 
Liu, H., Yan, D., and Wei, G., 2008, Deformation and metamorphism sequence of bikou terrane in the northwest margin of yangtze plate : implications for extension collapse and transition of songpan—garze orogenic belt: Acta Geologica Sinica, no. 04 , p. 464-474+578-579. (In Chinese with english abstract)

Long, X., 1991, Several questions of geochronic evolution in the mid-northeast segment of lLongmenshan Mountains: Journal of Chengdu College of geology, v. 18 , no. 1, p. 8-16. (In Chinese with english abstract)

Lovera, O. M., Richter, F. M., and Harrison, T. M., 1989, 40Ar/39Ar geothermometry

Ludwig, K. R., 2003, User's manual for Isoplot 3.00: a geochronological toolkit for Microsoft Excel: Berkeley Geochrongol. Center Special Publication, v. 4, p. 4793.

Paterson, S. R., Tobisch, O. T., and Bhattacharyya, T., 1989, Regional, structural and strain analyses of terranes in the Western Metamorphic Belt, Central Sierra

Luo, Z., 1991, The dynamical model of the lithospheric evolution in Longmenshan Orogenic Belt: Journal of Chengdu College of geology, no. 1, p. 1-7. (In Chinese with english abstract)

Ma, Y., Wang, G., and Hu, X., 1996, Tectonic deformation of Pengguan complex: Acta Geologica Sichuan, no. 02, p. 110-114. (In Chinese with english abstract)

Mattauer, M., Malavieille, J., Calassou, S., Lancelot, J., Roger, R., Hao, Z., Xu, Z. Q., and Hou, L. W., 1992, Le chaine Triassique de Songpan-Garze (Ouest Sichuan et est Tibet): Une chaine de plissement-decollement sur marge passive: Comptes Rendus de L'Academie Des Sciences, p. 619-626.

McDougall, I., and Harrison, T. M., 1988, Geochronology and thermo- chronology by the 40Ar/39Ar method, New York, Oxford University Press.

Meng, Q.-R., Wang, E., and Hu, J.-M., 2005, Mesozoic sedimentary evolution of the northwest Sichuan basin: Implication for continued clockwise rotation of the South China block: Geological Society of America Bulletin, v. 117, no. 3-4, p. 396-410, https://doi.org/10.1130/B25407.1. Nevada, California: Journal of structural geology, v. 11, no. 3, p. 255-273, 
1281 Phillips, D., Matchan, E. L., Honda, M., and Kuiper, K. F., 2017, Astronomical calibration of $40 \mathrm{Ar} / 39 \mathrm{Ar}$ reference minerals using high-precision, multicollector (ARGUSVI) mass spectrometry: Geochimica et Cosmochimica Acta, v. 196, p. 351-369, https://doi.org/10.1016/j.gca.2016.09.027.

Richardson, N. J., Densmore, A. L., Seward, D., Fowler, A., Wipf, M., Ellis, M. A., Yong, L., and Zhang, Y., 2008, Extraordinary denudation in the Sichuan Basin: Insights from low-temperature thermochronology adjacent to the eastern margin of the Tibetan Plateau: Journal of Geophysical Research, v. 113, no. B4, https://doi.org/10.1029/2006jb004739.

Robert, A., Pubellier, M., De Sigoyer, J., Vergne, J., Lahfid, A., Cattin, R., Findling, N., and Zhu, J., 2010a, Structural and thermal characters of the Longmen Shan (Sichuan, China): tectonophysics, v. 491, no. 1, p. 165-173, https://doi.org/10.1016/j.tecto.2010.03.018.

Robert, A., Zhu, J., Vergne, J., Cattin, R., Chan, L. S., Wittlinger, G., Herquel, G., de Sigoyer, J., Pubellier, M., and Zhu, L. D., 2010b, Crustal structures in the area of the 2008 Sichuan earthquake from seismologic and gravimetric data: Tectonophysics, v. 491, no. 1-4, p. 205-210, https://doi.org/10.1016/j.tecto.2009.11.010.

Roger, F., Jolivet, M., Cattin, R., and Malavieille, J., 2011, Mesozoic-Cenozoic tectonothermal evolution of the eastern part of the Tibetan Plateau (SongpanGarze, Longmen Shan area): insights from thermochronological data and simple thermal modelling: Geological Society, London, Special Publications, v. 353, no. 1, p. 9-25, https://doi.org/10.1144/sp353.2.

Roger, F., Malavieille, J., Leloup, P. H., Calassou, S., and Xu, Z., 2004, Timing of granite emplacement and cooling in the Songpan-Garzê Fold Belt (eastern Tibetan Plateau) with tectonic implications: Journal of Asian Earth Sciences, v. 22, no. 5, p. 465-481, https://doi.org/10.1016/s1367-9120(03)00089-0.

Royden, L. H., Burchfiel, B. C., and van der Hilst, R. D., 2008, The geological evolution of the Tibetan Plateau: science, v. 321, no. 5892, p. 1054-1058, https://doi.org/10.1126/science.1155371.

Sengör, A. M. C., 1984, The Cimmeride Orogenic System and the Tectonics of Eurasia: Geological Society of America Special Papers, v. 195, p. 1-74, 
Shen, Z.-K., Sun, J., Zhang, P., Wan, Y., Wang, M., Bürgmann, R., Zeng, Y., Gan, W., Liao, H., and Wang, Q., 2009, Slip maxima at fault junctions and rupturing of barriers during the 2008 Wenchuan earthquake: Nature Geoscience, v. 2, no. 10, p. 718-724, https://doi.org/10.1038/ngeo636.

Sláma, J., Košler, J., Condon, D. J., Crowley, J. L., Gerdes, A., Hanchar, J. M., Horstwood, M. S. A., Morris, G. A., Nasdala, L., Norberg, N., Schaltegger, U., Schoene, B., Tubrett, M. N., and Whitehouse, M. J., 2008, Plešovice zircon A new natural reference material for $\mathrm{U}-\mathrm{Pb}$ and $\mathrm{Hf}$ isotopic microanalysis: Chemical Geology, v. 249, no. 1, p. 1-35, https://doi.org/10.1016/j.chemgeo.2007.11.005.

Stacey, J. S., and Kramers, J. D., 1975, Approximation of terrestrial lead isotope evolution by a two-stage model: Earth and Planetary Science Letters, v. 26, no. 2, p. 207-221, https://doi.org/10.1016/0012-821X(75)90088-6.

Tian, Y., Kohn, B. P., Phillips, D., Hu, S., Gleadow, A. J., and Carter, A., 2016, Late Cretaceous-earliest Paleogene deformation in the Longmen Shan fold-andthrust belt, eastern Tibetan Plateau margin: Pre-Cenozoic thickened crust?: Tectonics, p. 1-20, https://doi.org/10.1002/2016TC004182.

Wallis, S. R., Tsujimori, T., Aoya, M., Kawakami, T., Terada, K., Suzuki, K., and Hyodo, H., Cenozoic and Mesozoic metamorphism in the Longmenshan orogen: Implications for geodynamic models of eastern Tibet, in Proceedings AGU Fall Meeting Abstracts2003, p. 745-748.

Wang, E., Kirby, E., Furlong, K. P., van Soest, M., Xu, G., Shi, X., Kamp, P. J. J., and Hodges, K. V., 2012a, Two-phase growth of high topography in eastern Tibet during the Cenozoic: Nature Geosci, v. 5, no. 9, p. 640-645, https://doi.org/10.1038/ngeo1538.

Wang, E., Meng, K., Chu, J. J., Wang, G., and Chen, Z., East Tibet Detachment: Evidence for the uplift mechanism of the Longmen Shan fault belt2012b.

Wang, Q., Liang, B., Xie, Q., and He, W., 2000, Research on microstructures and deformation conditions of the Qingchuan fault zone: Journal of Mineral Petrology, v. 87, no. 01, p. 87-90. (In Chinese with english abstract)

Wei, C., 1994, Metamorphism and its geological significance of the Bikou Group in the Shanxi-Gansu-Sichuan border region: Acta Geologica Sinica, v. 68, no. 03, p. 
Weislogel, A. L., Graham, S. A., Chang, E. Z., Wooden, J. L., and Gehrels, G. E., 2010,

1348

1349

1350

1351

1352

1353

1354

1355

1356

1357

1358

1359

1360

1361

1362

1363

1364

1365

1366

1367

1368

1369

1370

1371

1372

1373

1374

1375

Detrital zircon provenance from three turbidite depocenters of the MiddleUpper Triassic Songpan-Ganzi complex, central China: Record of collisional tectonics, erosional exhumation, and sediment production: Geological Society of America Bulletin, v. 122, no. 11-12, p. 2041-2062, https://doi.org/10.1130/b26606.1.

Weller, O. M., St-Onge, M. R., Waters, D. J., Rayner, N., Searle, M. P., Chung, S. L., Palin, R. M., Lee, Y. H., and Xu, X., 2013, Quantifying Barrovian metamorphism in the Danba Structural Culmination of eastern Tibet: Journal of Metamorphic Geology, v. 31, no. 9, p. 909-935, https://doi.org/10.1111/jmg.12050.

West, D. P., and Lux, D. R., 1993, Dating mylonitic deformation by the 40Ar-39Ar method: An example from the Norumbega Fault Zone, Maine: Earth and Planetary Science Letters, v. 120, no. 3-4, p. 221-237, https://doi.org/10.1016/0012-821X(93)90241-Z.

Worley, B. A., and Wilson, C. J., 1996, Deformation partitioning and foliation reactivation during transpressional orogenesis, an example from the Central Longmen Shan, China: Journal of Structural Geology, v. 18, no. 4, p. 395-411, https://doi.org/10.1016/0191-8141(95)00095-U.

Xia, Z., 1993, Syntectonic regional epimetamorphism of the Triassic terrigenous detrital rocks in the Songpan-Ganze orogneic belt during the early Yanshanian orogney: Acta Geologica Sichuan, no. 03, p. 189-192. (In Chinese with english abstract)

Xu, C., Wells, M. L., Yan, D.-P., Qiu, L., Zhou, Y., and Zhang, Y., 2020, Phase equilibria and geochronology of Triassic blueschists in the Bikou terrane and Mesozoic tectonic evolution of the northwestern margin of the Yangtze Block (SW China): Journal of Asian Earth Sciences, v. 201, p. 104513, https://doi.org/https://doi.org/10.1016/j.jseaes.2020.104513.

Xu, Z., Hou, L., and Wang, Z., 1992, Orogenic process of the Songpan-Ganzé Orogenic belt of China., Geological Publishing House, Beijing, 1-189 p.:

Xu, Z., Ji, S., Li, H., Hou, L., Fu, X., and Cai, Z., 2008, Uplift of the Longmen Shan range and the Wenchuan earthquake: Episodes, v. 31, no. 3, p. 291-301, 
Xue, Z., Martelet, G., Lin, W., Faure, M., Chen, Y., Wei, W., Li, S., and Wang, Q., 2017, Mesozoic crustal thickening of the Longmenshan belt (NE Tibet, China) by imbrication of basement slices: insights from structural analysis, petrofabric and magnetic fabric studies, and gravity modeling: Tectonics, p. 3110-3134, https://doi.org/10.1002/2017TC004754.

Xue, Z., Shang, Q., Jiang, W., Wang, Q., and Li, S., 2016, Emplacement age and tectonic implications of the brecciated limestone at the edge of the Longmenshan klippe: Science China Earth Sciences, v. 59, no. 3, p. 590-600, https://doi.org/10.1007/s11430-015-5209-0.

Yan, D., Zhou, M., Li, S., and Wei, G., 2011, Structural and geochronological constraints on the Mesozoic-Cenozoic tectonic evolution of the Longmen Shan thrust belt, eastern Tibetan Plateau: Tectonics, v. 30, no. 6, p. 1-24, https://doi.org/10.1029/2011TC002867.

Yan, D., Zhou, M., Wei, G., Gao, J., Liu, S., Xu, P., and Shi, X., 2008, The Pengguan tectonic dome of Longmen Mountains, Sichuan Province: Mesozoic denudation of a Neoproterozoic magmatic arc-basin system: Science in China Series D: Earth Sciences, v. 51, no. 11, p. 1545-1559, https://doi.org/10.1007/s11430008-0126-0.

Yan, D.-P., Qiu, L., Wells, M. L., Zhou, M.-F., Meng, X., Lu, S., Zhang, S., Wang, Y., and Li, S.-B., 2018, Structural and Geochronological Constraints on the Early Mesozoic North Longmen Shan Thrust Belt: Foreland Fold-Thrust Propagation of the SW Qinling Orogenic Belt, Northeastern Tibetan Plateau: Tectonics, v. 37, no. 12, p. 4595-4624, https://doi.org/10.1029/2018tc004986.

Yan, Q., Wang, Z., Hanson, A., Druschke, P., Yan, Z., Liu, D., Jian, P., Song, B., Wang, T., and Jiang, C., 2003, SHRIMP age and geochemistry of the Bikou volcanic terrane: implications for Neoproterozoic tectonics on the northern margin of the Yangtze Craton: Acta Geologica Sinica (English Edition), v. 77, no. 4, p. 479490.

Yan, Z., Tian, Y., Li, R., Vermeesch, P., Sun, X., Li, Y., Rittner, M., Carter, A., Shao, C., Huang, H., and Ji, X., 2019, Late Triassic tectonic inversion in the upper Yangtze Block: Insights from detrital zircon $\mathrm{U}-\mathrm{Pb}$ geochronology from southwestern Sichuan Basin: Basin Research, v. 31, no. 1, p. 92-113, 
Yin, A., The Songpan-ganzi terrane of Tibet: was it a part of South China since the Neopreoterozoic, in Proceedings 2015 GSA Annual Meeting in Baltimore, Maryland, USA, 2015, Volume 47, Geological Society of America, p. 38.

Yin, A., and Nie, S., 1993, An indentation model for the North and South China collision and the development of the Tan-Lu and Honam fault systems, Eastern Asia: Tectonics, v. 12, no. 4, p. 801-813.

Yuan, C., Zhou, M.-F., Sun, M., Zhao, Y., Wilde, S., Long, X., and Yan, D., 2010, Triassic granitoids in the eastern Songpan Ganzi Fold Belt, SW China: Magmatic response to geodynamics of the deep lithosphere: Earth and Planetary Science Letters, v. 290, no. 3-4, p. 481-492, https://doi.org/10.1016/j.eps1.2010.01.005.

Yuan, H., Zhang, Z., and Zhang, P., 1991, The uplift and cooling histories of Laojungou granite in the western margin of the central Longmen Mountain: Journal of Chengdu College of geology, v. 18, no. 1, p. 17-22. (In Chinese with english abstract)

Zhang, H., Parrish, R., Zhang, L., Xu, W., Yuan, H., Gao, S., and Crowley, Q. G., 2007, A-type granite and adakitic magmatism association in Songpan-Garze fold belt, eastern Tibetan Plateau: Implication for lithospheric delamination: Lithos, v. 97, no. 3-4, p. 323-335, https://doi.org/10.1016/j.lithos.2007.01.002.

Zhang, H., Zhang, L., Harris, N., Jin, L., and Yuan, H., 2006a, U-Pb zircon ages, geochemical and isotopic compositions of granitoids in Songpan-Garze fold belt, eastern Tibetan Plateau: constraints on petrogenesis and tectonic evolution of the basement: Contributions to Mineralogy and Petrology, v. 152, no. 1, p. 75-88, https://doi.org/10.1007/s00410-006-0095-2.

Zhang, H.-P., Liu, S.-F., Yang, N., Zhang, Y.-Q., and Zhang, G.-W., 2006b, Geomorphic characteristics of the Minjiang drainage basin (eastern Tibetan Plateau) and its tectonic implications: New insights from a digital elevation model study: The Island Arc, v. 15, no. 2, p. 239-250, https://doi.org/10.1111/j.14401738.2006.00524.x.

Zhang, K.-J., Li, B., Wei, Q.-G., Cai, J.-X., and Zhang, Y.-X., 2008, Proximal provenance of the western Songpan-Ganzi turbidite complex (Late Triassic, eastern Tibetan plateau): Implications for the tectonic amalgamation of China: 
Sedimentary Geology, v. 208, no. 1-2, p. 36-44, https://doi.org/10.1016/j.sedgeo.2008.04.008.

Zhang, P., Shen, Z., Wang, M., Gan, W., Bürgmann, R., Molnar, P., Wang, Q., Niu, Z., Sun, J., Wu, J., Hanrong, S., and Xinzhao, Y., 2004, Continuous deformation of the Tibetan Plateau from global positioning system data: Geology, v. 32, no. 9, p. 809, https://doi.org/10.1130/g20554.1.

Zhang, Y. X., Li, B., Wei, Q. G., Wang, Y., and Zhang, K. J., 2006c, Detrital zircon provenance of the Late Triassic Songpan-Ganzi complex: Sedimentary record of collision of the North and South China blocks: Comment and Reply: COMMENT: Geology, v. 34, no. 1, p. e107-e107, https://doi.org/10.1130/g22944.1.

Zhang, Z., Wang, Y., Chen, Y., Houseman, G. A., Tian, X., Wang, E., and Teng, J., 2009, Crustal structure across Longmenshan fault belt from passive source seismic profiling: Geophysical Research Letters, v. 36, no. 17, p. L17310-, https://doi.org/10.1029/2009g1039580.

Zhang, Z., Yuan, X., Chen, Y., Tian, X., Kind, R., Li, X., and Teng, J., 2010, Seismic signature of the collision between the east Tibetan escape flow and the Sichuan Basin: Earth and Planetary Science Letters, v. 292, no. 3-4, p. 254-264, https://doi.org/10.1016/j.eps1.2010.01.046.

Zhao, Y., 2007, Mesozoic granitoids in Eastern Songpan-Garze: Geochemistry, petrogenesis and tectonic implications [Doctor: Graduate school of the Chinese Academy of Sciences, $111 \mathrm{p}$.

Zheng, Y., Kong, P., and Fu, B., 2014, Time constraints on the emplacement of klippen in the Longmen Shan thrust belt and tectonic implications: Tectonophysics, v. 634, p. 44-54, https://doi.org/10.1016/j.tecto.2014.07.018.

Zheng, Y., Li, H., Sun, Z., Wang, H., Zhang, J., Li, C., and Cao, Y., 2016, New geochronology constraints on timing and depth of the ancient earthquakes along the Longmen Shan fault belt, eastern Tibet: Tectonics, v. 35, no. 12, p. 27812806, https://doi.org/10.1002/2016TC004210.

Zhou, M., Yan, D., Kennedy, A. K., Li, Y., and Ding, J., 2002, SHRIMP U-Pb zircon geochronological and geochemical evidence for Neoproterozoic arcmagmatism along the western margin of the Yangtze Block, South China: Earth and Planetary Science Letters, v. 196, no. 1, p. 51-67, 
1479 Zhou, M., Yan, D., Vasconcelos, P. M., Li, J., and Hu, R., 2008, Structural and geochronological constraints on the tectono-thermal evolution of the Danba domal terrane, eastern margin of the Tibetan plateau: Journal of Asian Earth Sciences, v. 33, no. 5, p. 414-427, https://doi.org/10.1002/2016TC004210. 


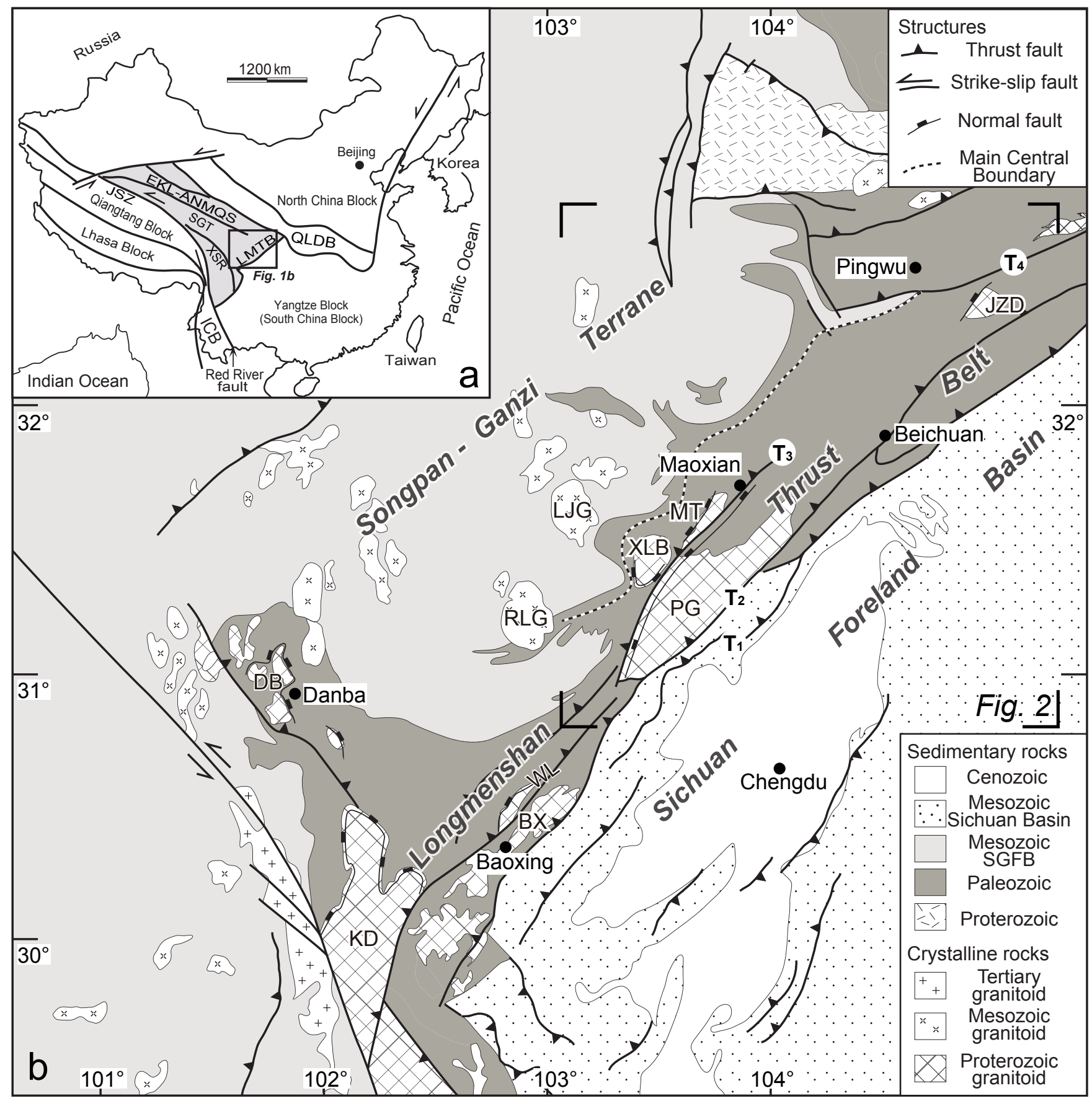




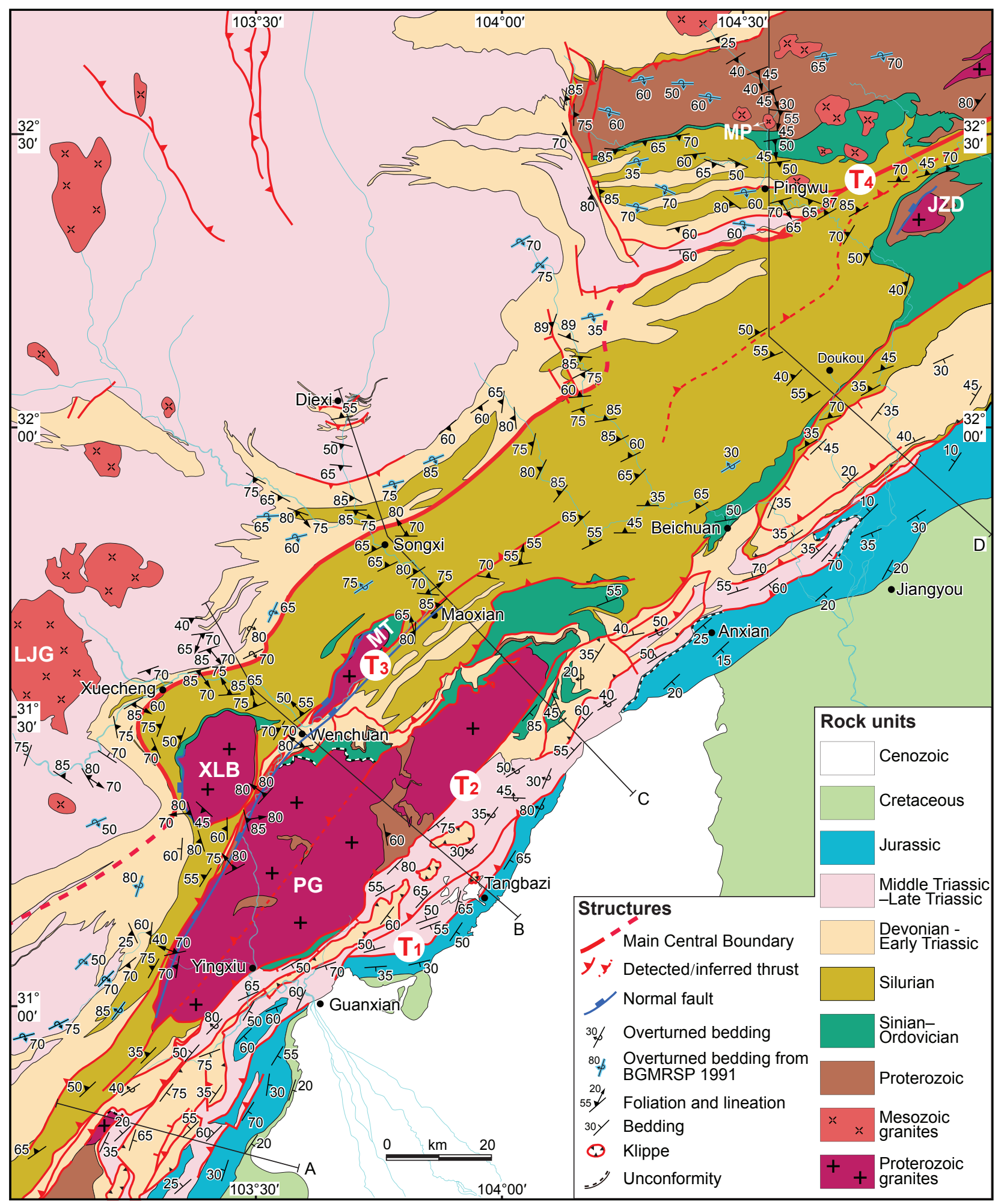




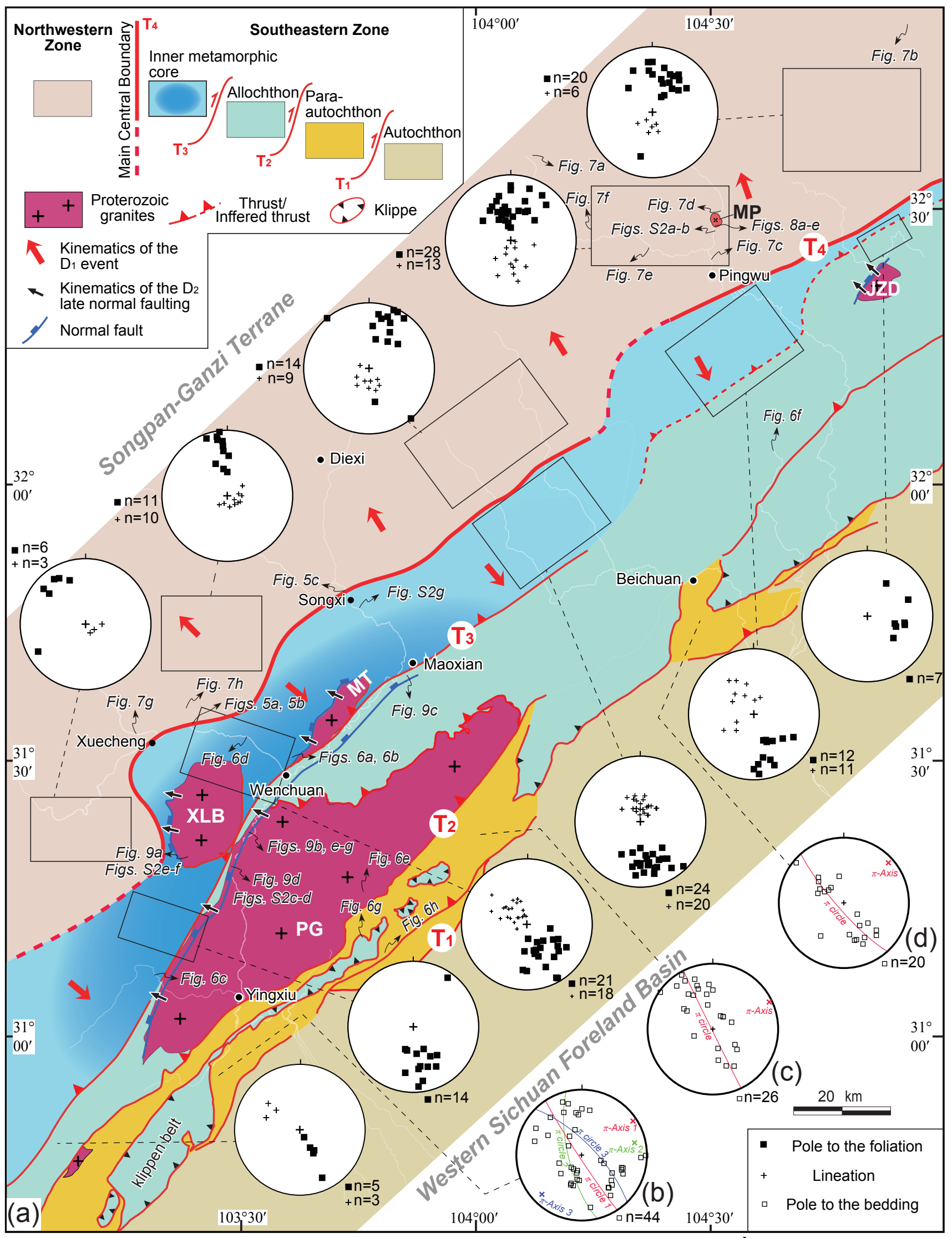


Figure 4

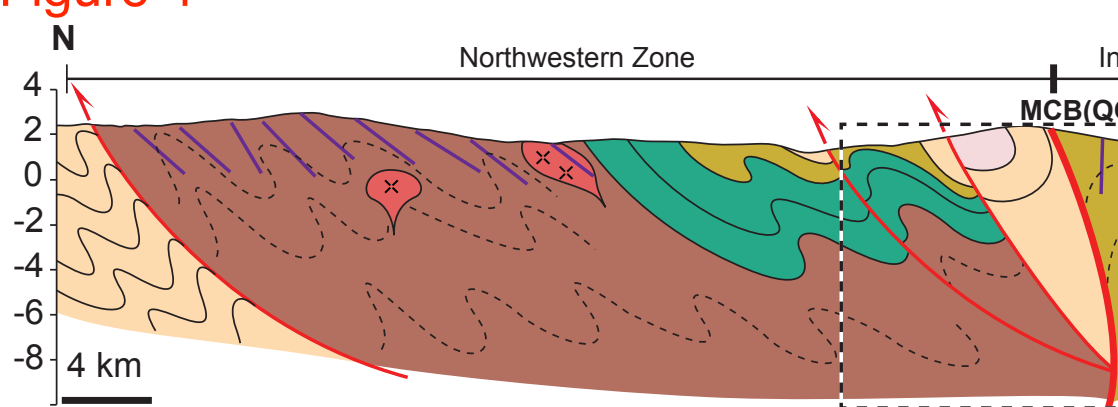
Inner metamorphic core $\mathbf{S} \mid \mathbf{N W}$ Allochthon Para-autochthon
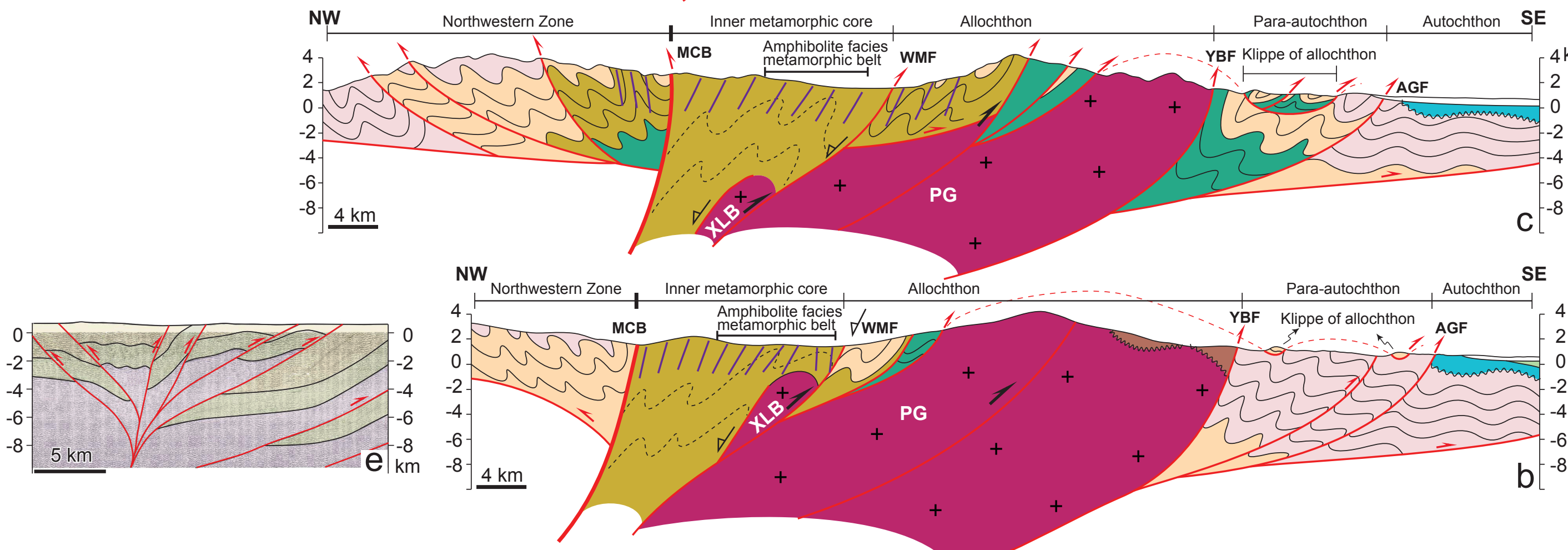

nner metamorphic core

Allochthon

Para-autochthon

Autochthon SE

$4 \mathrm{~km}$
2
0
-2
-4
-6
-8

\section{Legends}

D/ // $\mathrm{J}_{3}$-Eocene SE-thrusting and NW-normal faulting

$w^{v^{2}}$ Unconformity /Foliation

(1) $\mathrm{T}_{3}-\mathrm{J}_{1} \mathrm{SE}$-ward and NW/N-ward double-vergent thrusting

$\therefore$ i' Inferred bedding $\begin{array}{ll}\text { Devonian - } & \text { Middle-Late } \\ \text { Triassic } & \text { Jurassic }\end{array}$

Cretaceous

Cenozoic

Proterozoic metamorphic belt
WMF
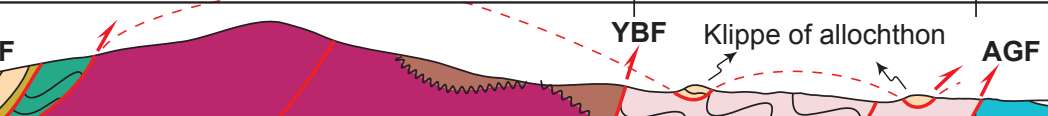

PG
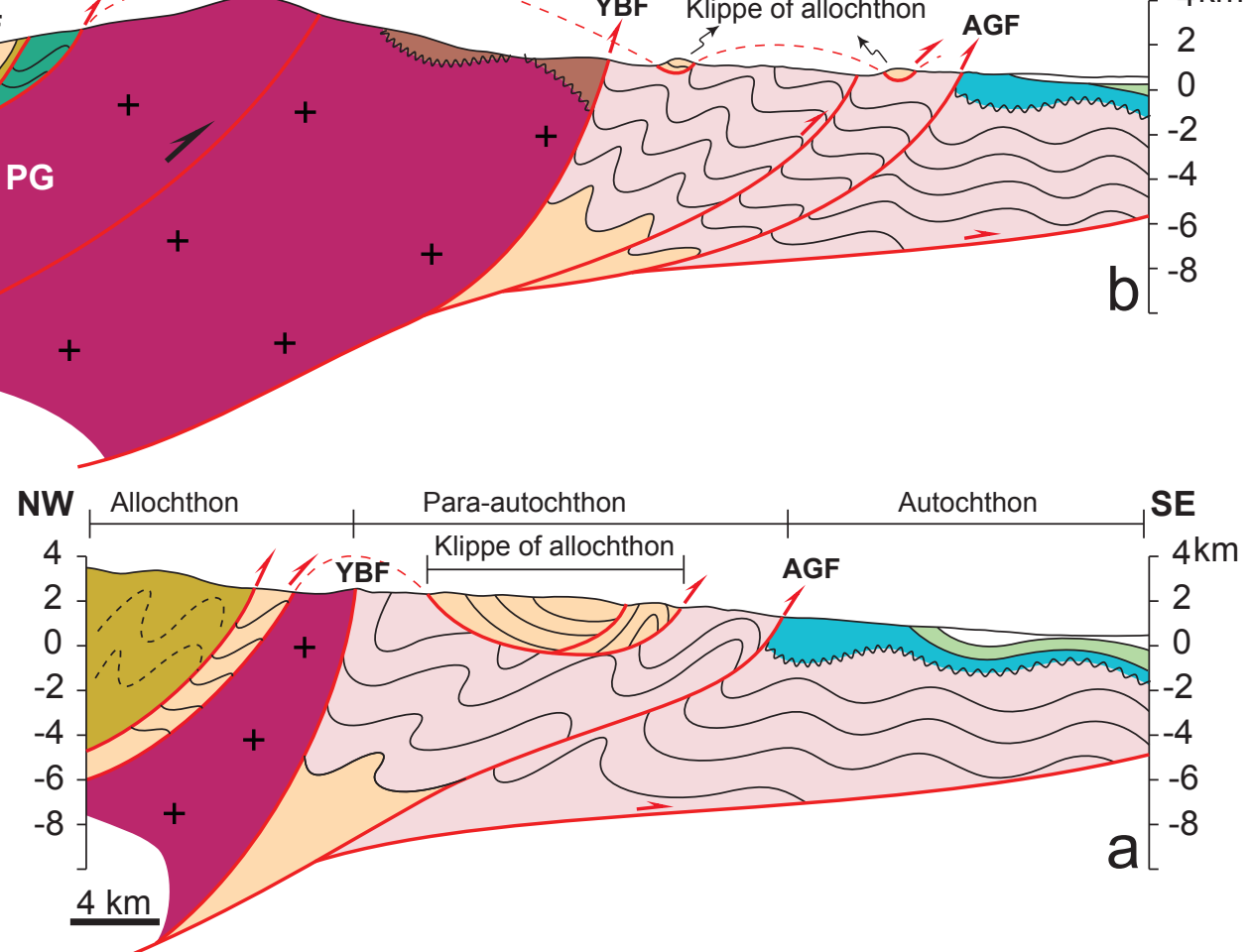
Figure 5

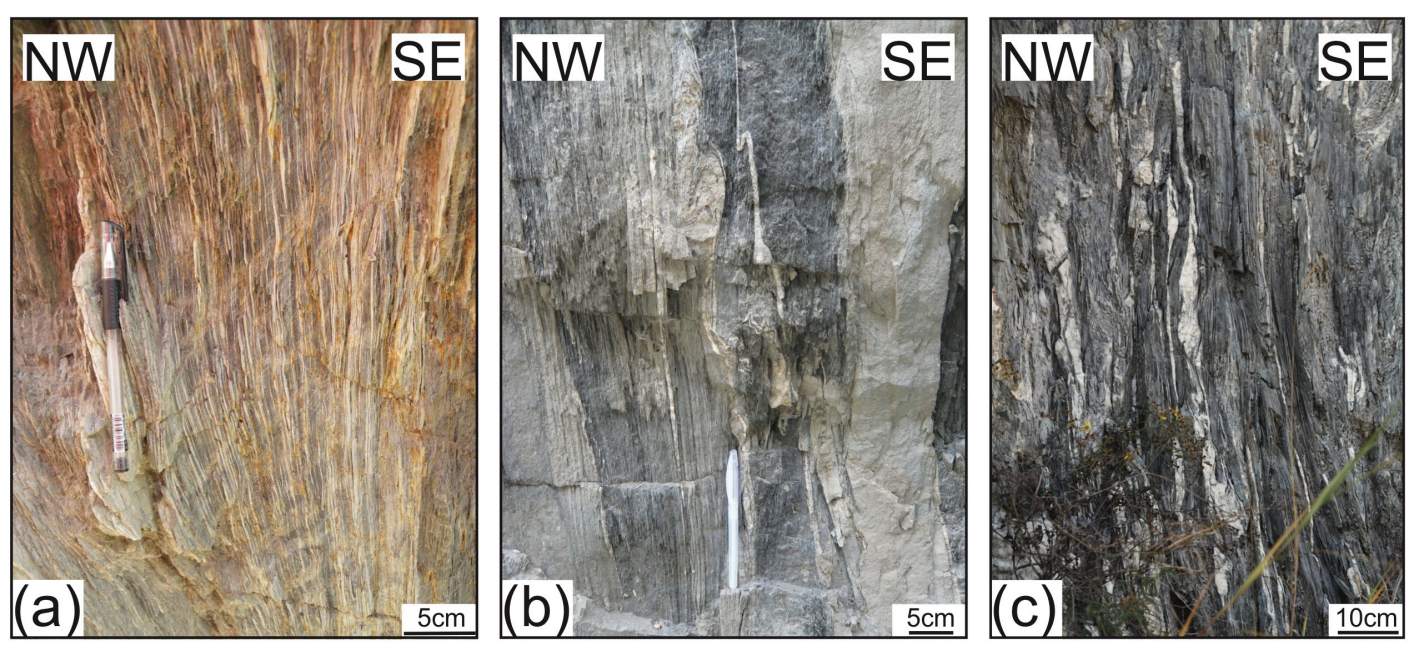



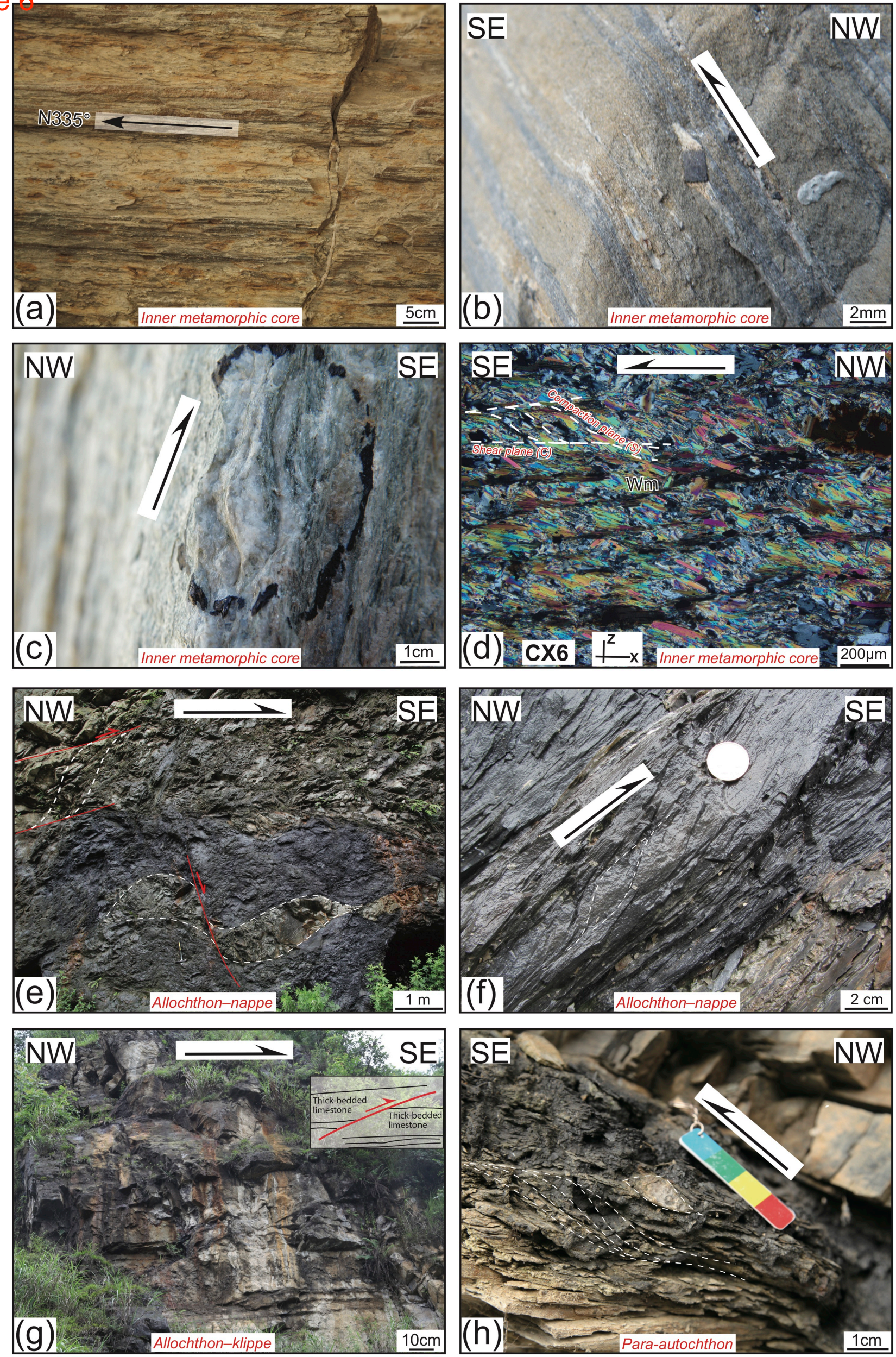
Figure 7
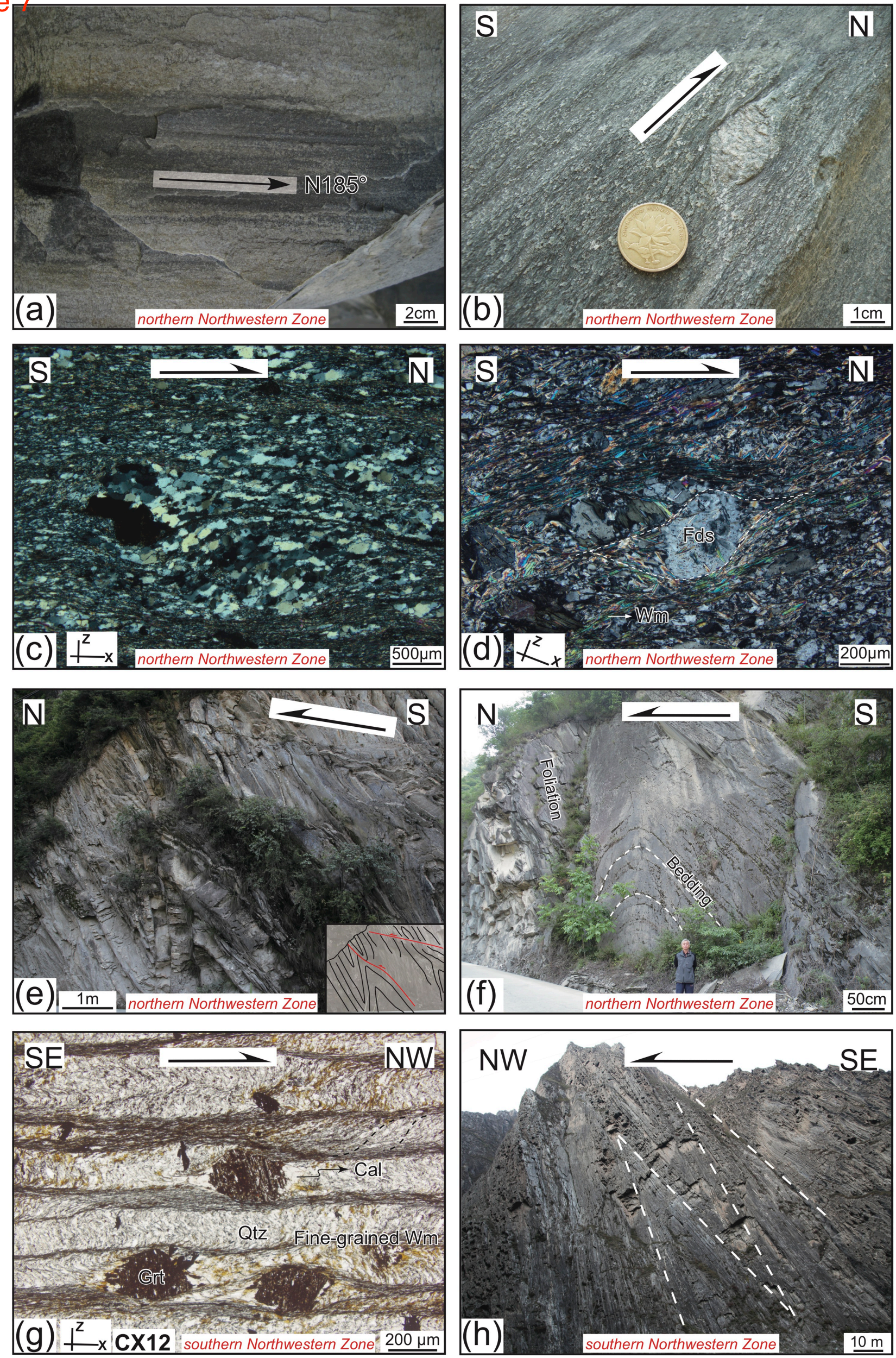
Figure 8

30 meters north to the south margin of the Mupi pluton

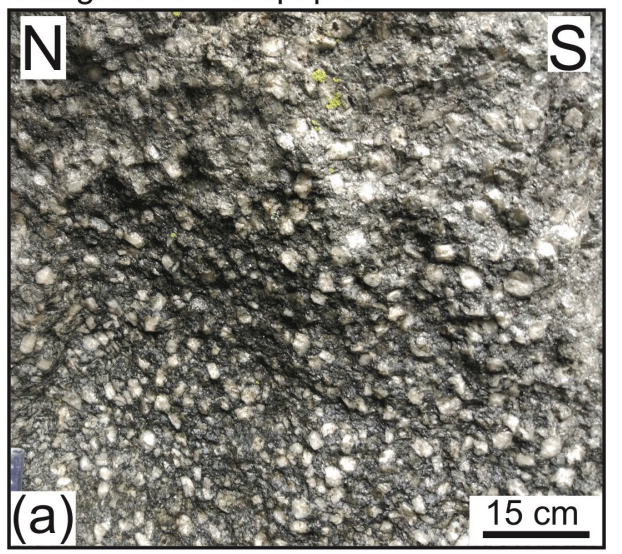

10-15 meters north to the south margin of the Mupi pluton

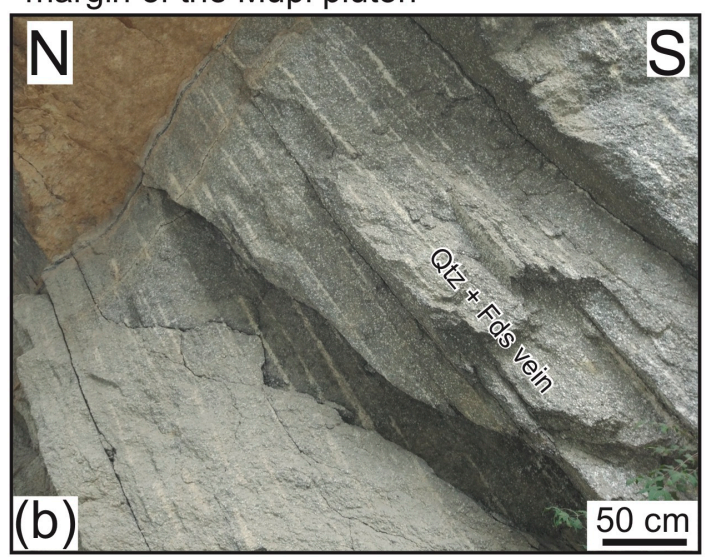

South margin of the Mupi pluton
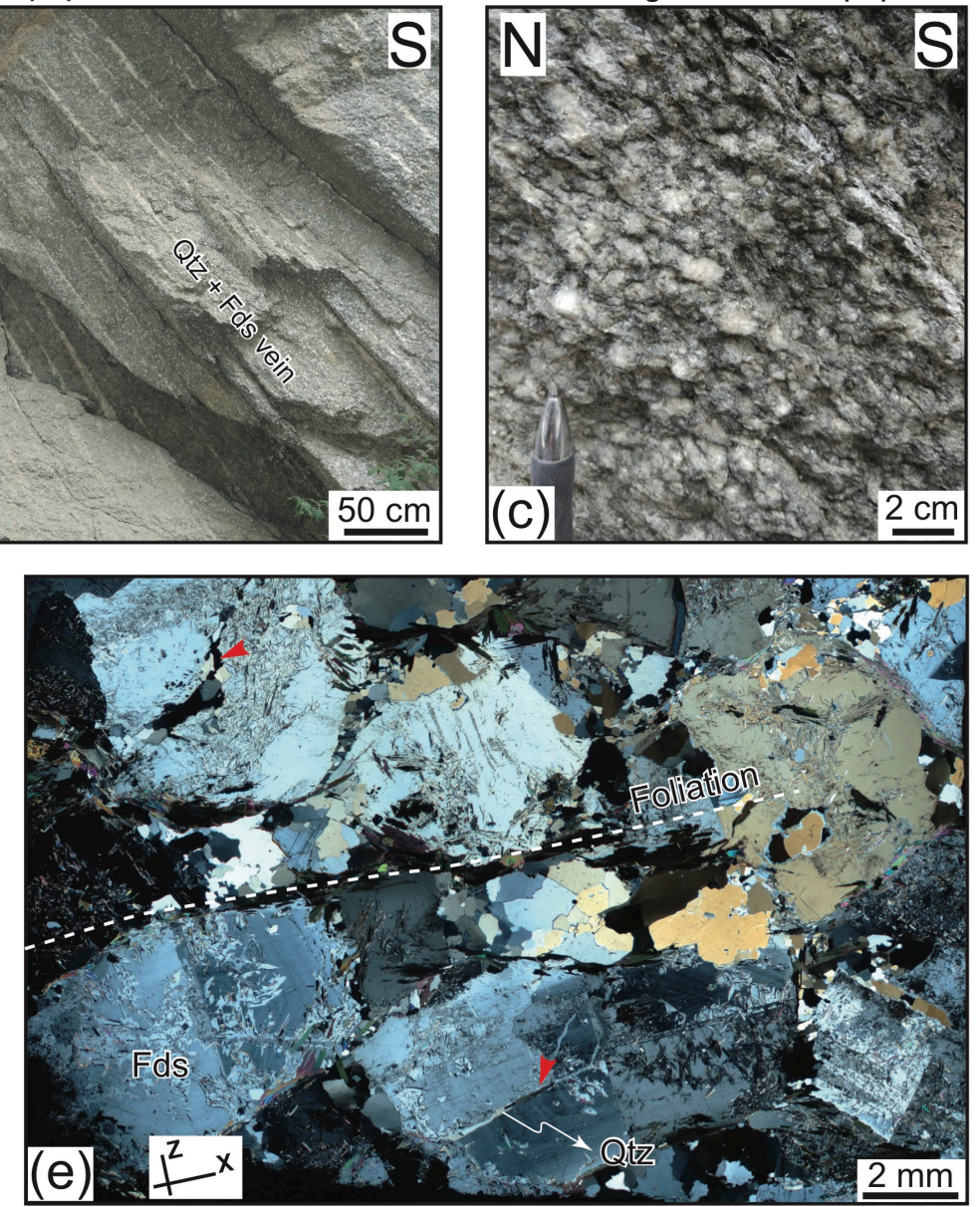

e) $t^{2} x$

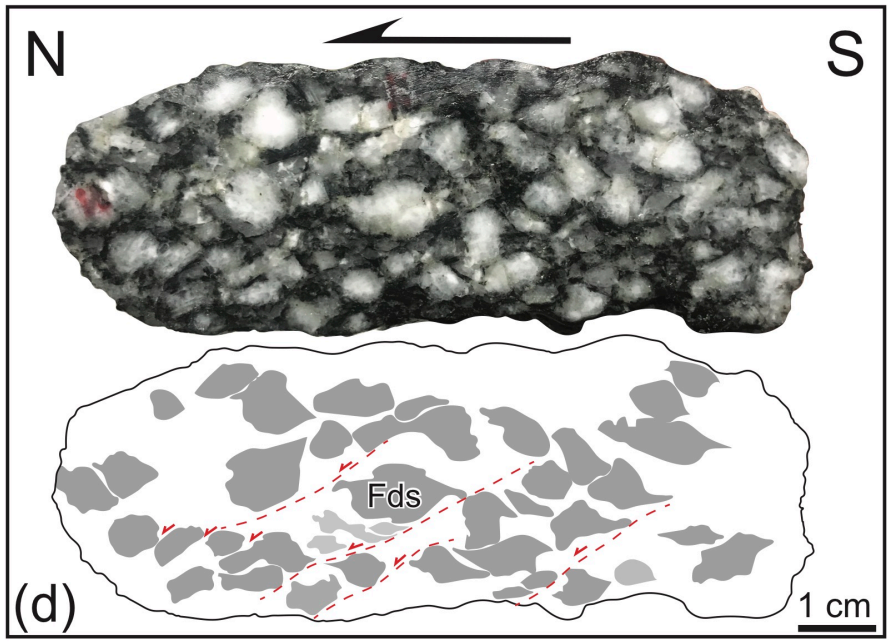



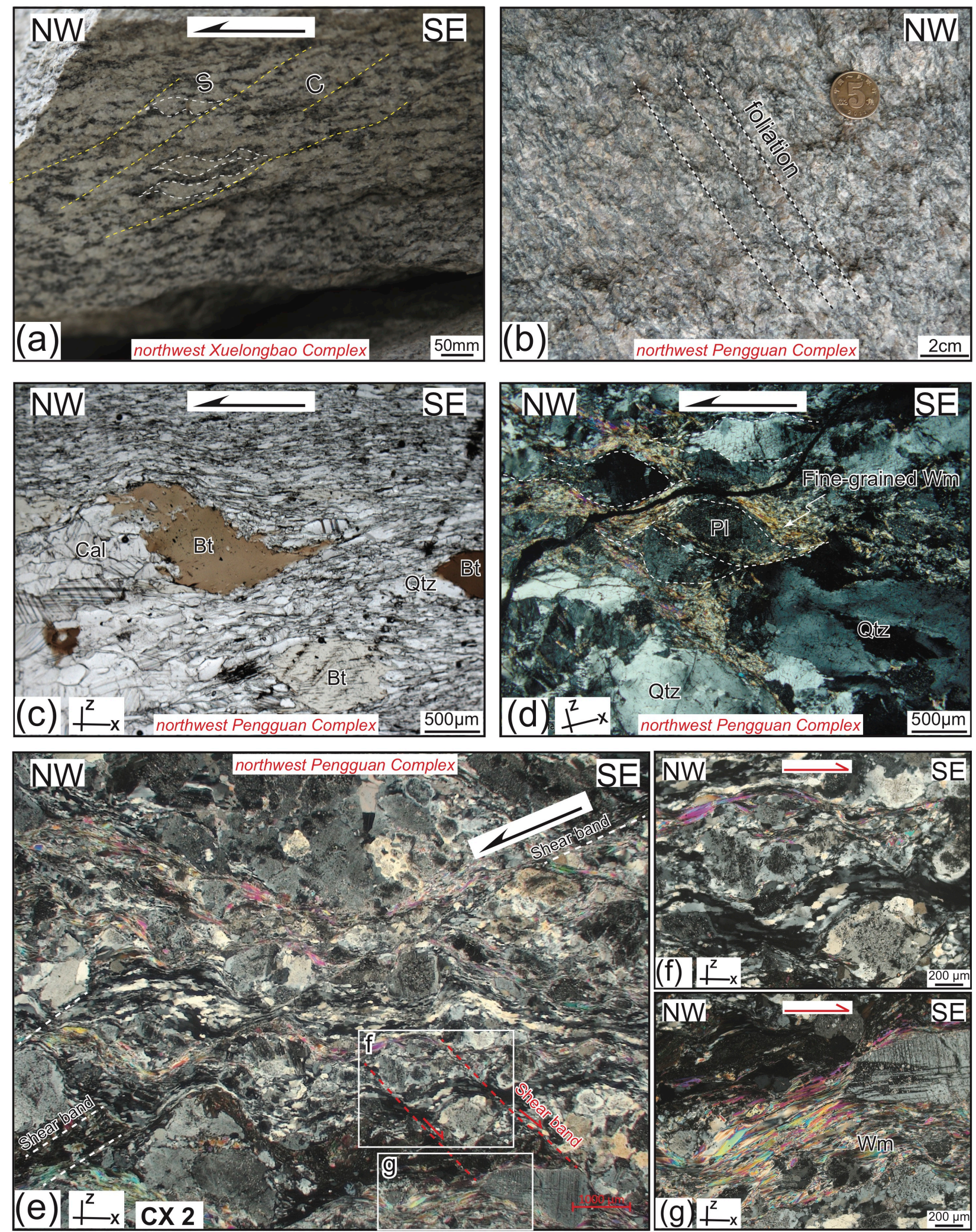
Figure 10

Northwestern Zone
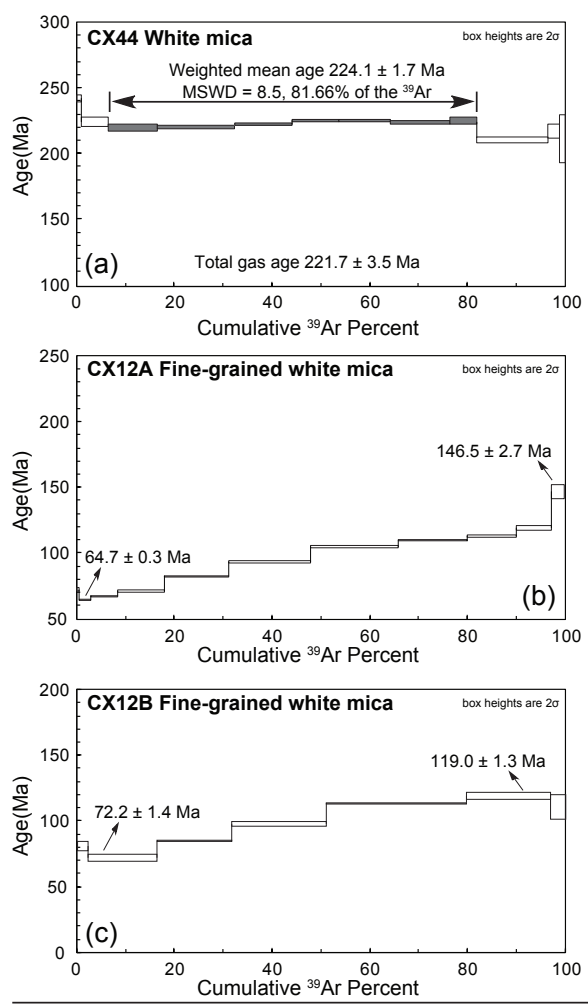

Southeastern Zone -Inner metamorphic core
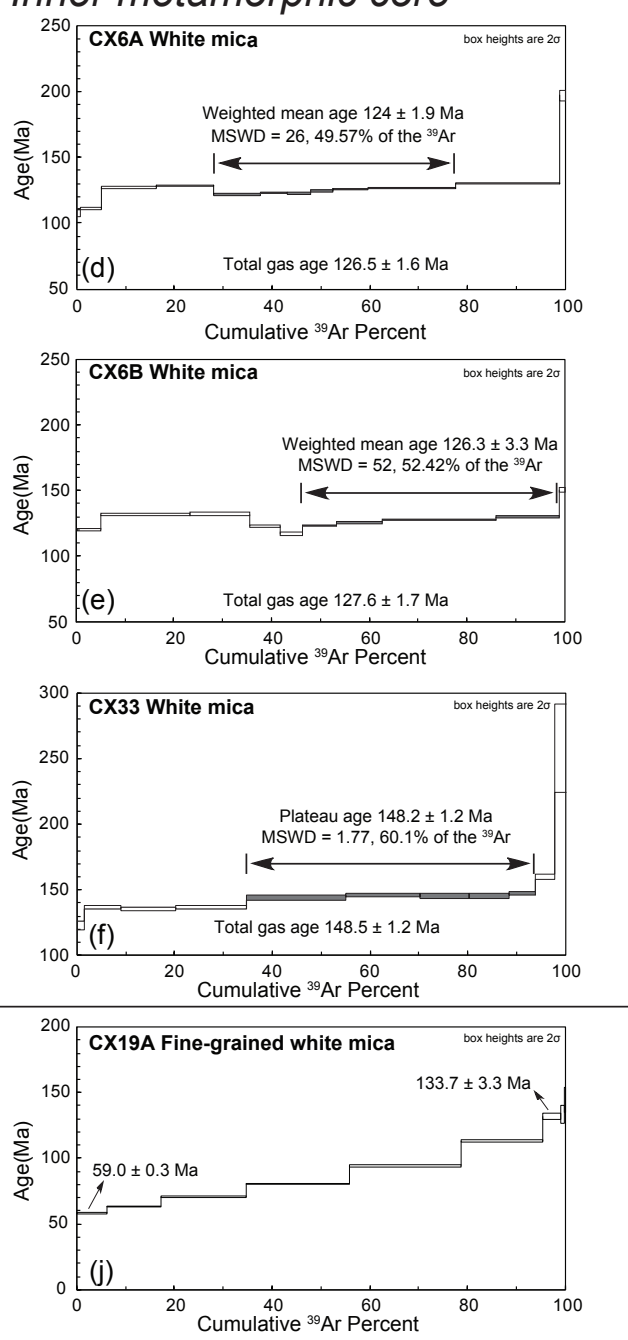

Basement Complex
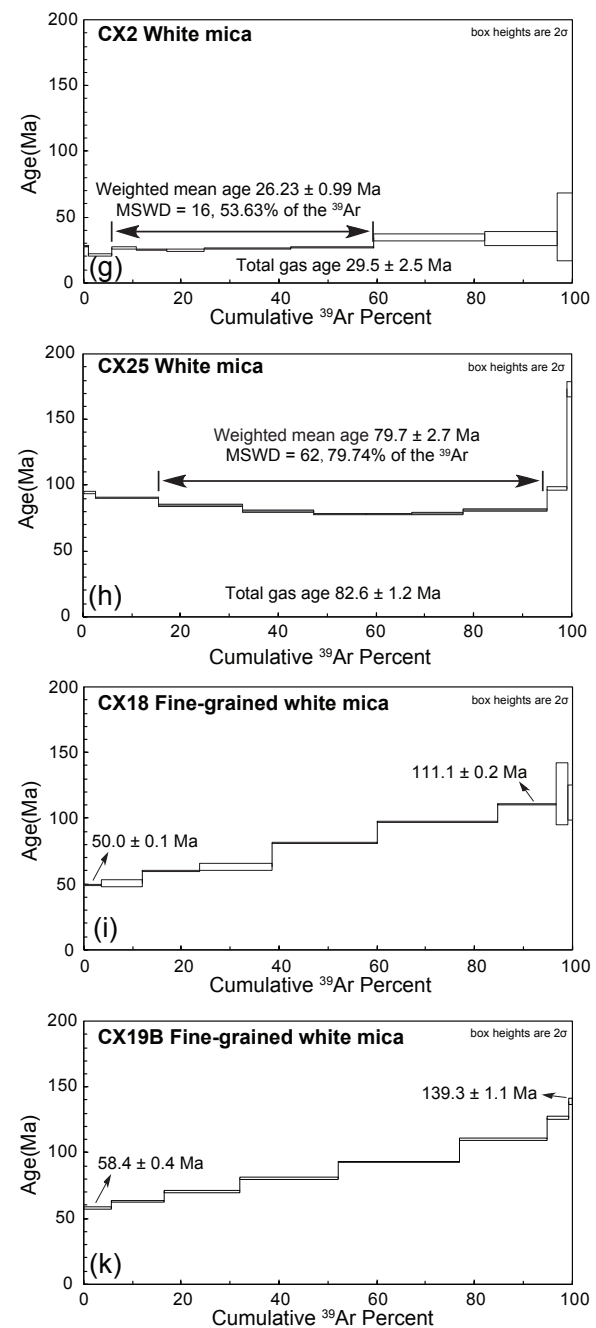

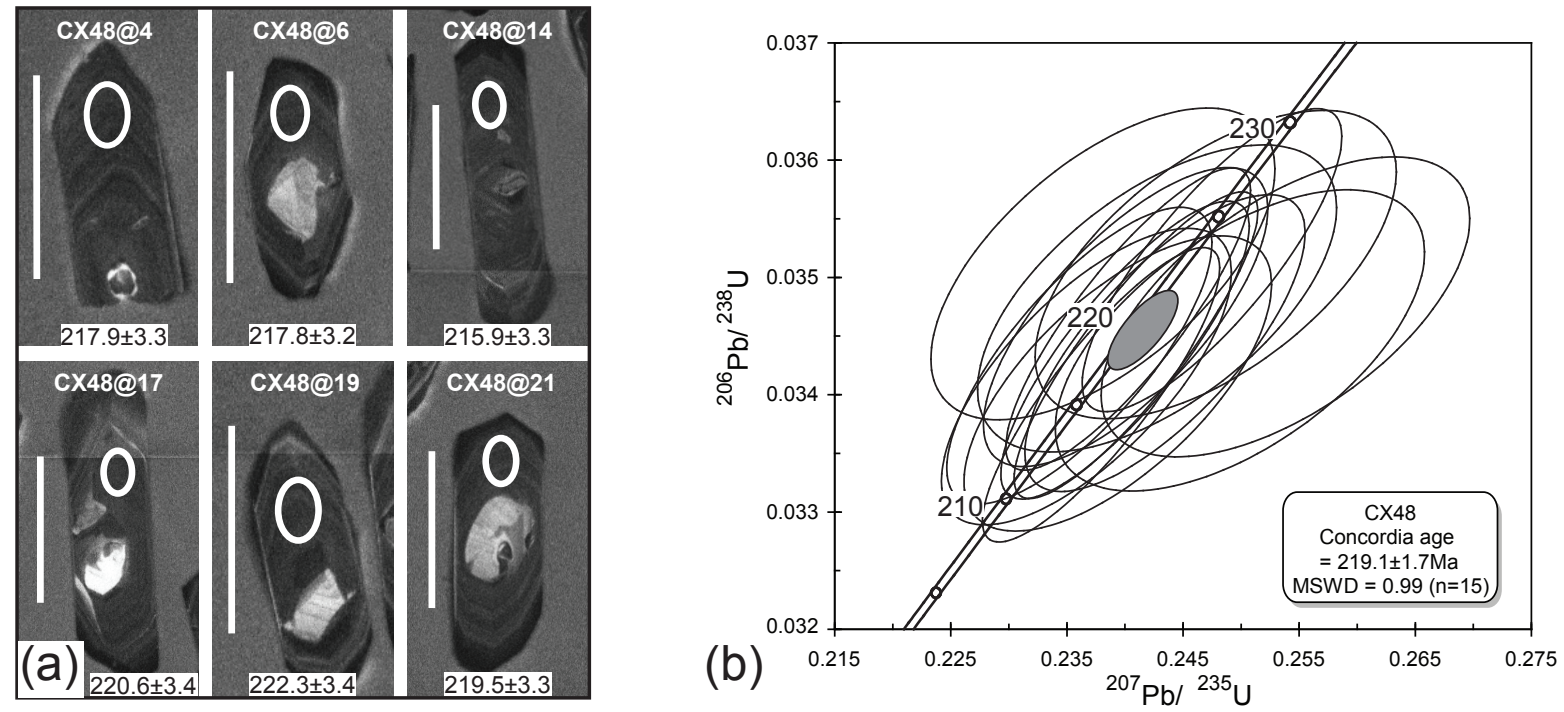


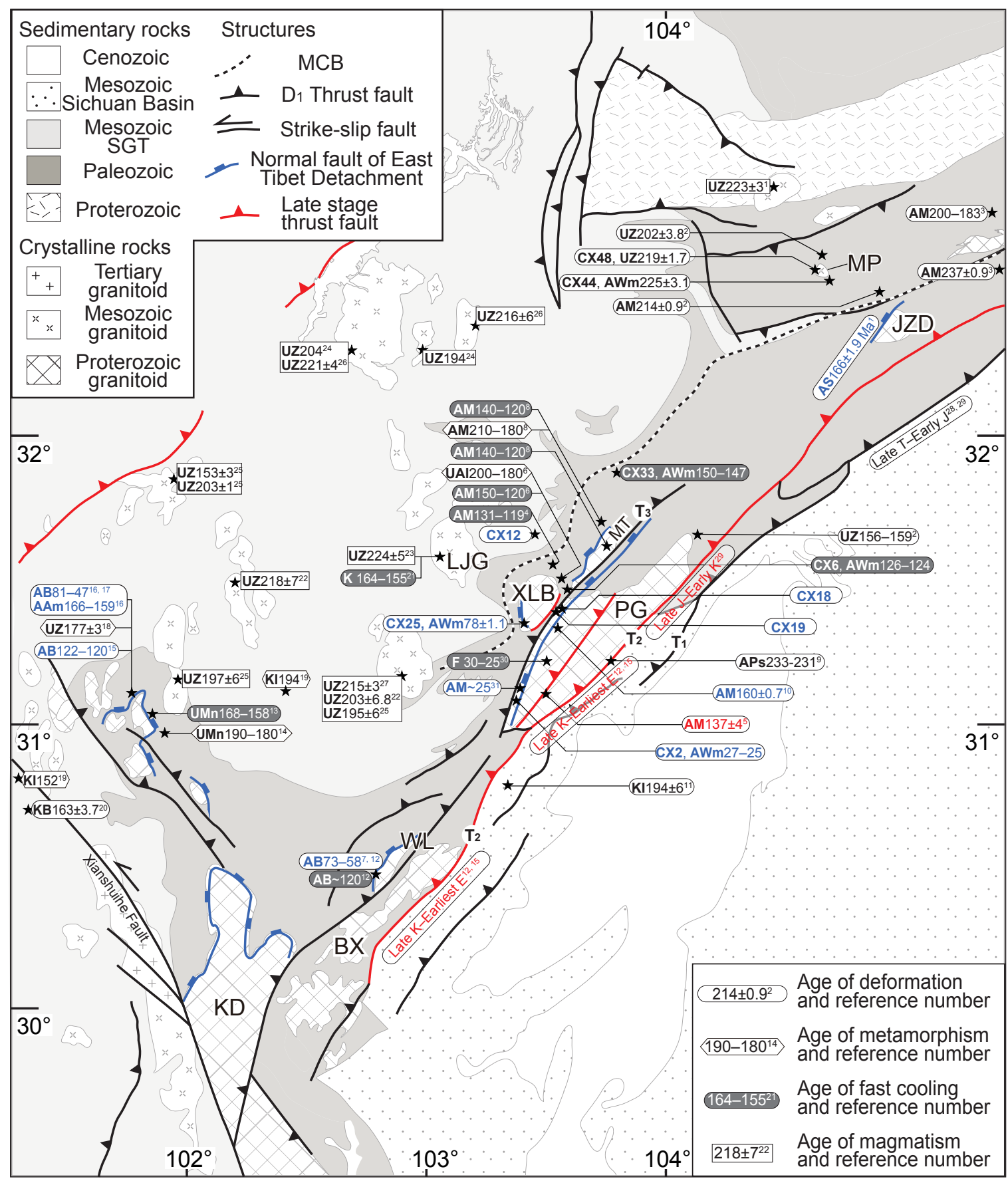


Figure 13

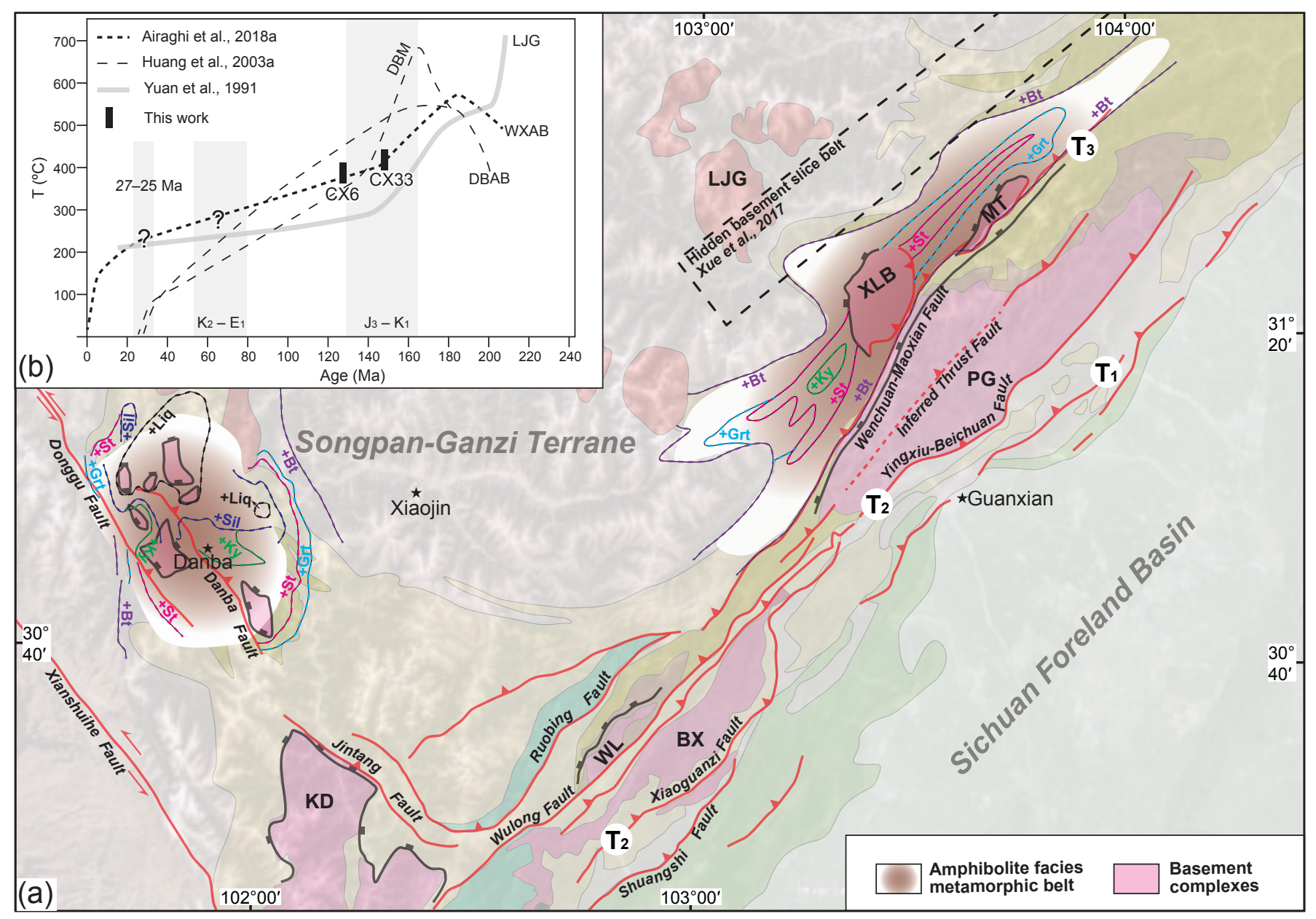



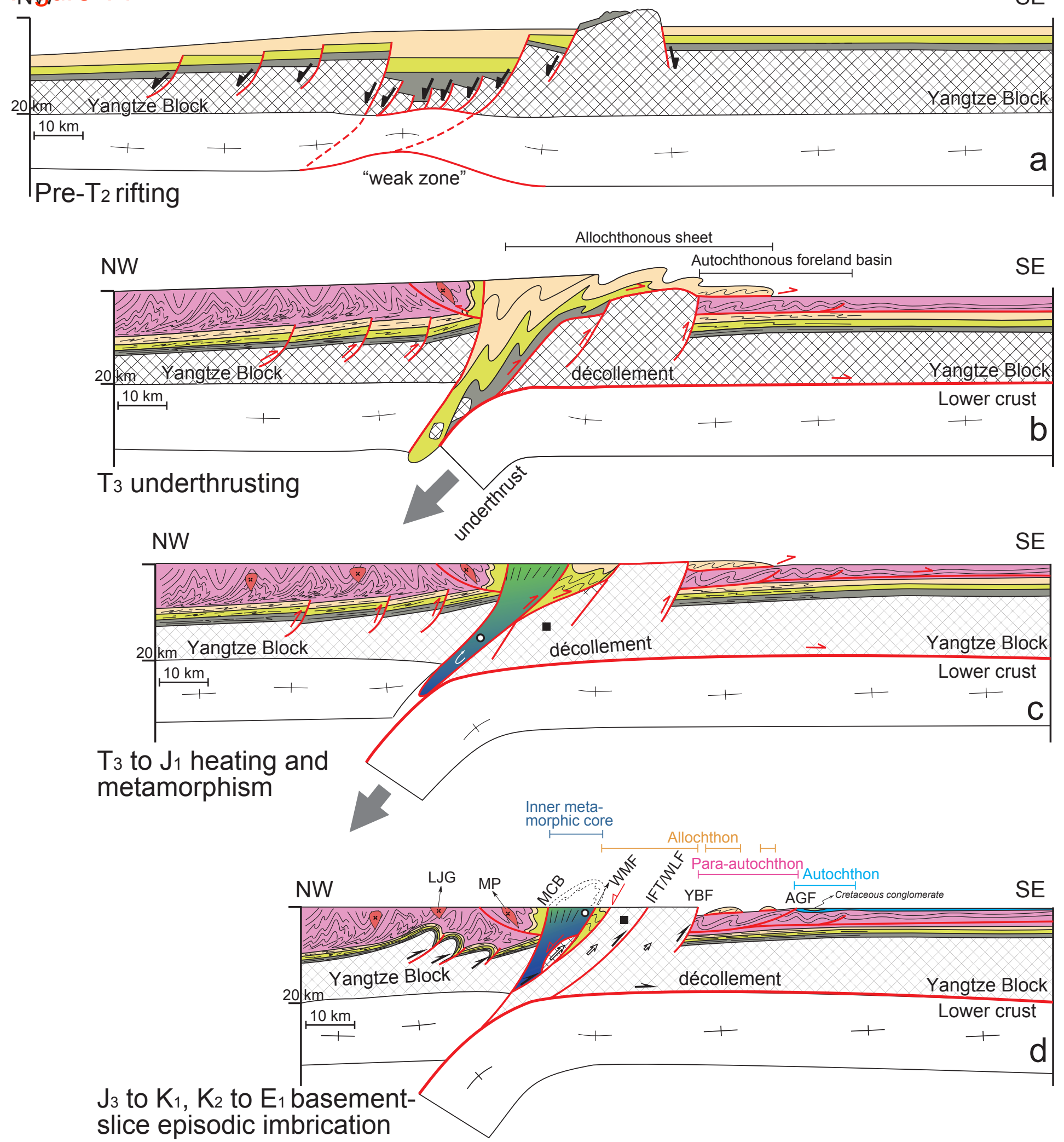

$\checkmark$ Pre $T_{2}$ normal fault 1 Reverse fault during $\mathrm{T}_{3}-\mathrm{aJ}_{1},{ }_{1}$ Episodic and synchronous NW-normal faulting and SE-thrusting during $\mathrm{J}_{3}-\mathrm{K}_{1}, \mathrm{~K}_{2}-\mathrm{E}_{1}$

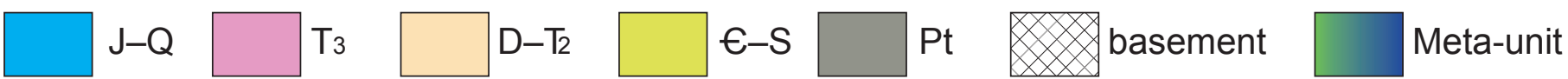


Zhenhua Xue, Wei Lin, Yang Chu, Michel Faure, Yan Chen, Wenbin Ji, and Huaning Qiu, 2021, An intracontinental orogen exhumed by basement-slice imbrication in the Longmenshan Thrust Belt of the Eastern Tibetan Plateau: GSA Bulletin, https://doi.org/10.1130/B35826.1.

\section{Supplemental Material}

Figure S1. (a) Reflection image show location of the crack in feldspar, same crack in lower middle of Figure 8e from the Mupi pluton. (b) Same crack in Figure a, cross-polarized light. (c) Back scattered electron image show points selected for energy-dispersive X-ray spectrometer measurement. (d and h) Energy-dispersive X-ray spectra of point 1 and point 6 in the crack show typical feature of quartz. (e-g) Energy dispersive X-ray spectra of point 2, point 3, and point 5 indicate component of feldspar with different $\mathrm{Ca}$ content.

Figures S2. Features of the samples selected for ${ }^{40} \mathrm{Ar}-{ }^{39} \mathrm{Ar}$ dating. Shear plane is defined by finegrained white mica (c-d) or white mica ( $(\mathrm{a}-\mathrm{b}, \mathrm{e}-\mathrm{f}$, and $\mathrm{g}$ ). (h) Field observation of sample CX6, where sigma-shaped quartz lens indicate a top-to-the-SE thrusting. Mineral abbreviations after Kretz (1983). CPL—cross-polarized light; PPL—plain-polarized light.

Figure S3. All samples show high radiogenic ${ }^{40} \mathrm{Ar}$ (Table S2) and almost all steps are clustered at the ${ }^{39} \mathrm{Ar} /{ }^{40} \mathrm{Ar}$ axis that do not define a real inverse isochron line. The initial ${ }^{40} \mathrm{Ar} /{ }^{36} \mathrm{Ar}$ ratio originate from the inverse isochron line is meaningless as well. Most of the step-ages calculated both by using initial ${ }^{40} \mathrm{Ar} /{ }^{36}$ of 298.56 (Lee et al., 2006) and from the "inverse isochron", show nearly no differences (Table S2). Thus, the inverse isochron ages, though identical to their weighted mean ages or plateau ages, are meaningless and have not been discussed in the main text.

Table S1. Detailed SIMS U-Pb zircon results of sample CX48

Table S2. ${ }^{40} \mathrm{Ar} /{ }^{\beta 9} \mathrm{Ar}$ VG3600 Furnace Step-Heating analytical results 

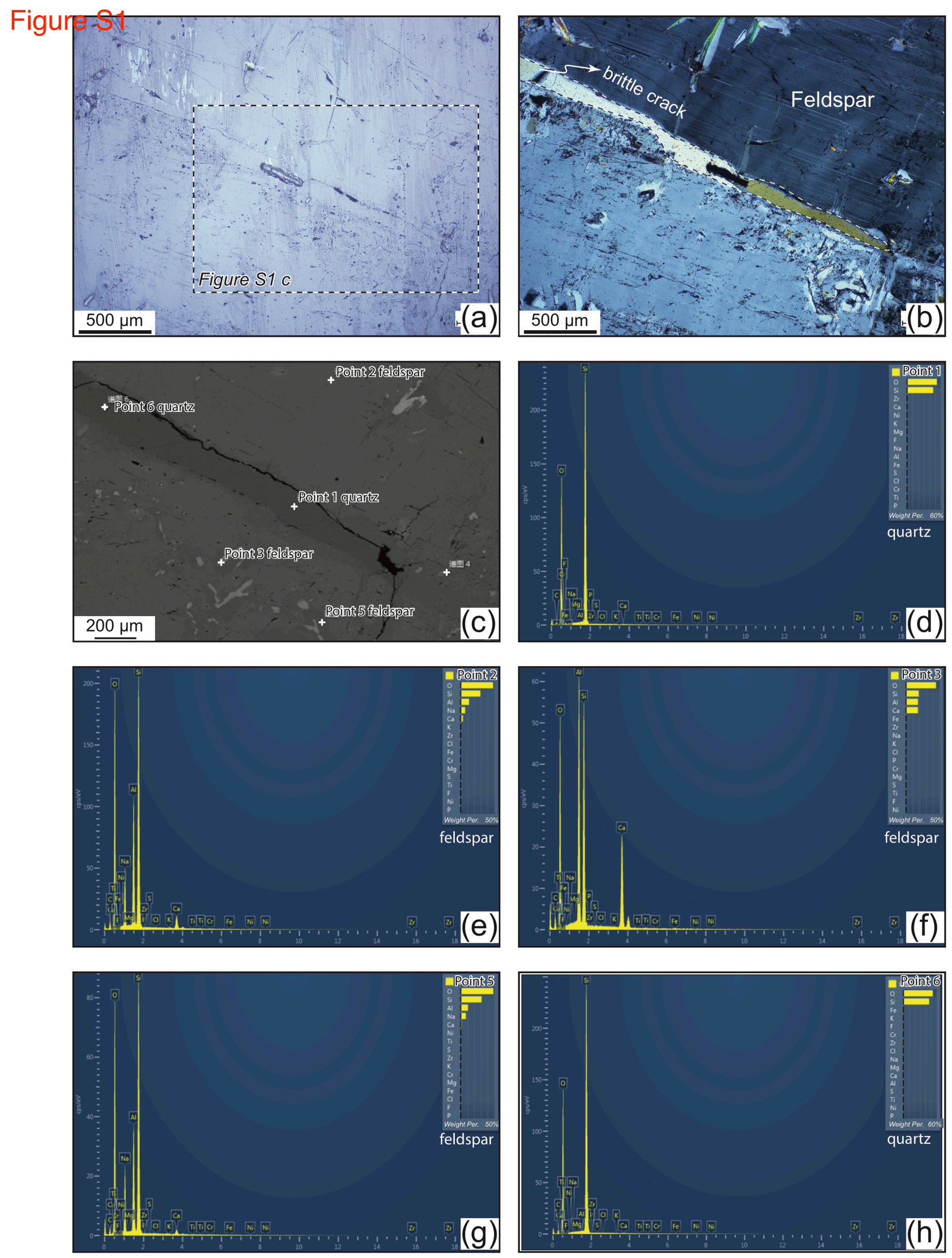
Figure S2
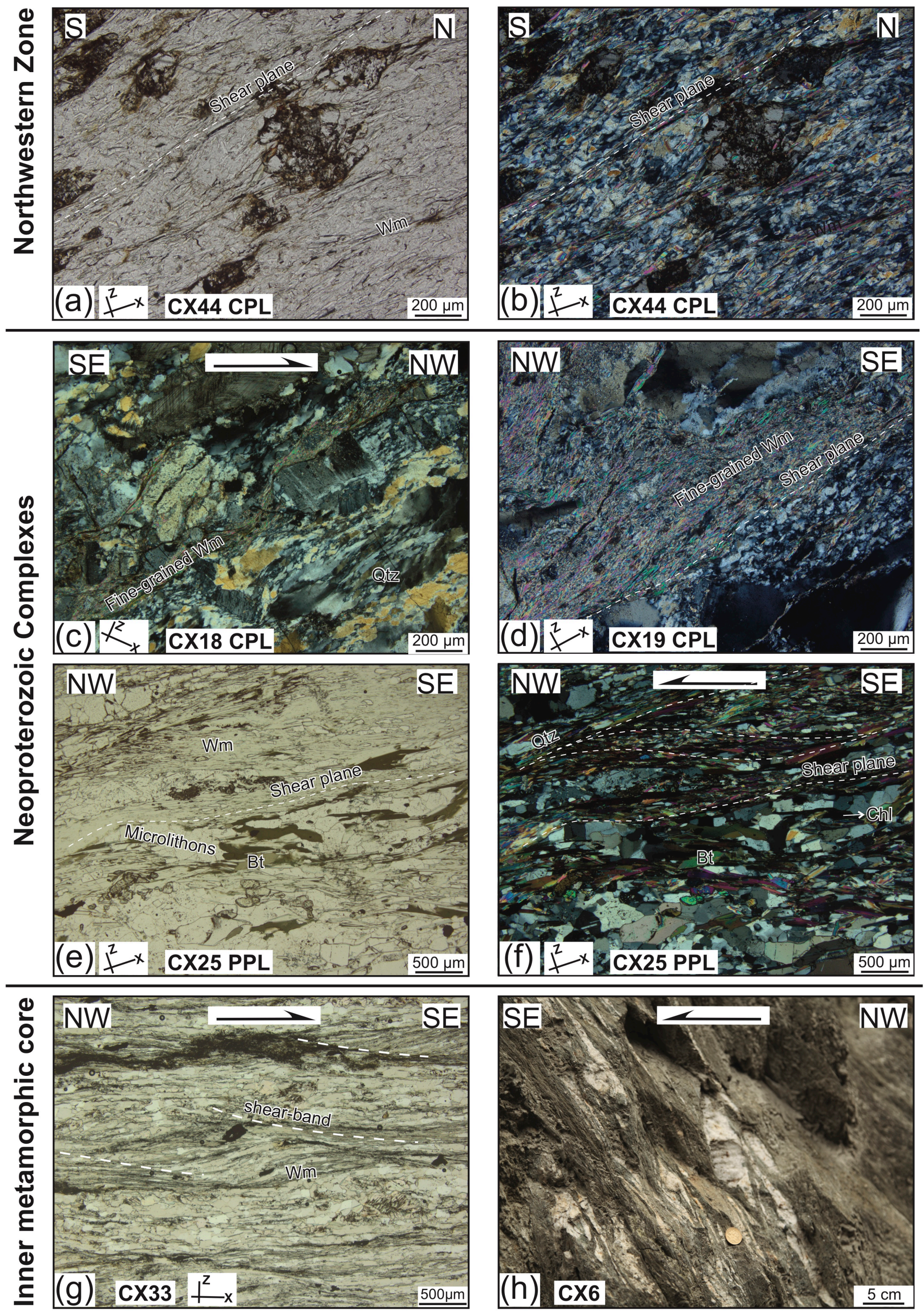
Figure S3

Northwestern Zone

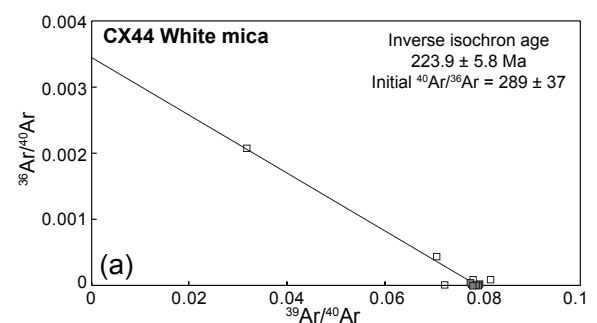

Southeastern Zone -Inner metamorphic core
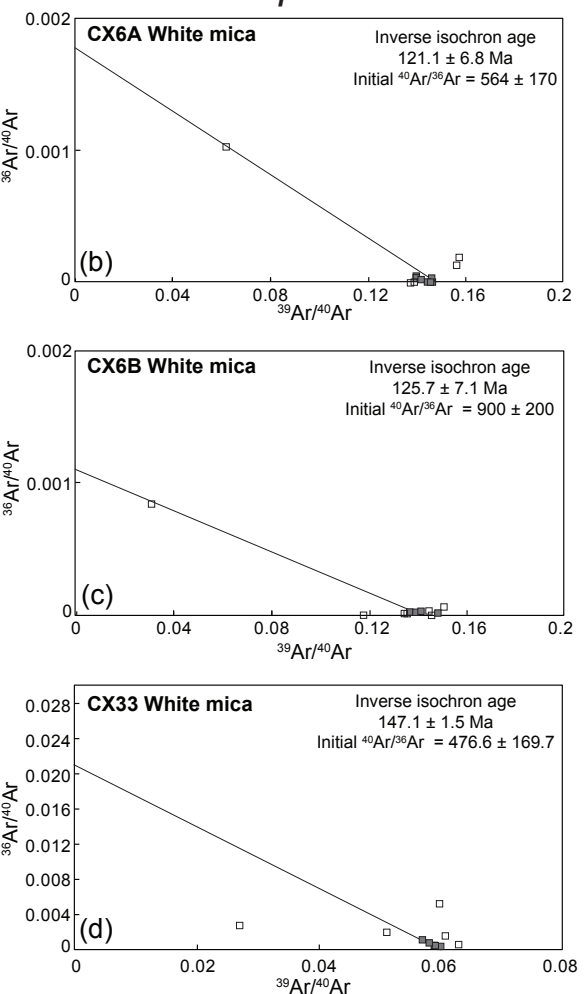

\section{Basement Complex}
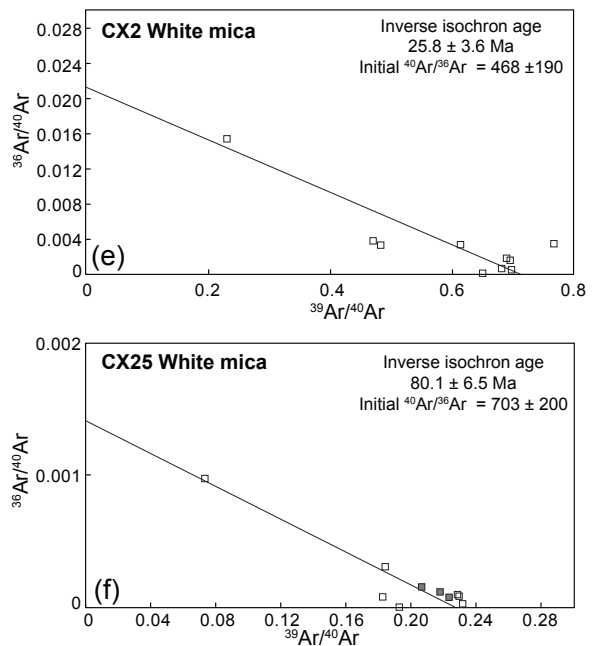